Florida International University FIU Digital Commons

\title{
Iran and the Constitutionalism: History and Evolution and the Impact on International Relations
}

Farshad Ghodoosi

fghod001@fiu.edu

DOI: $10.25148 /$ etd.FIDC004078

Follow this and additional works at: https:// digitalcommons.fiu.edu/etd

Part of the Constitutional Law Commons, International Relations Commons, Islamic Studies Commons, and the Near and Middle Eastern Studies Commons

\section{Recommended Citation}

Ghodoosi, Farshad, "Iran and the Constitutionalism: History and Evolution and the Impact on International Relations" (2018). FIU Electronic Theses and Dissertations. 3720.

https://digitalcommons.fiu.edu/etd/3720 


\title{
FLORIDA INTERNATIONAL UNIVERSITY
}

Miami, Florida

\section{IRAN AND CONSTITUTIONALISM: HISTORY AND EVOLUTION AND THE IMPACT ON INTERNATIONAL RELATIONS}

\author{
A dissertation submitted in partial fulfillment of \\ the requirements for the degree of \\ DOCTOR OF PHILOSOPHY \\ in \\ INTERNATIONAL RELATIONS
}

by

Farshad Ghodoosi 
To: $\quad$ Dean Michael R. Heithaus

College of Arts, Sciences and Education

This dissertation, written by Farshad Ghodoosi, and entitled Iran and Constitutionalism: History and Evolution and the Impact on International Relations, having been approved in respect to style and intellectual content, is referred to you for judgment.

We have read this dissertation and recommend that it be approved.

Félix E. Martín

Thomas A. Breslin

Iqbal Akhtar

Mohiaddin Mesbahi, Major Professor

Date of Defense: March 28, 2018

The dissertation of Farshad Ghodoosi is approved.

Dean Michael R. Heithaus
College of Arts, Sciences and Education

College of Arts, Sciences and Education

Andrés G. Gil

Vice President for Research and Economic Development and Dean of the University Graduate School

Florida International University, 2018 


\title{
ABSTRACT OF THE DISSERTATION
}

\section{IRAN AND CONSTITUTIONALISM: HISTORY AND EVOLUTION AND THE IMPACT ON INTERNATIONAL RELATIONS}

\author{
by
}

\author{
Farshad Ghodoosi
}

Florida International University, 2018

Miami, Florida

\section{Professor Mohiaddin Mesbahi, Major Professor}

The sweeping changes in the Middle East, so-called the "Arab Spring", necessitate revisiting constitutionalism in the region. This task entails a fresh look at the idea of rule of law and constitutionalism amongst the people of the Middle East. One of the widely misconceived and yet understudied constitutional movements in the Middle East belongs to Iran. A new perspective on the trajectory of constitutionalism in Iran would better equip us to comprehend rule of law in the Middle East. From the 1905 Constitutional movement to the 1979 Revolution, Iran has undergone major changes. Each transformation created a rupture with the preceding order fostering a fresh look at rule of law in Iran. The current studies have mainly concentrated on the political and social aspects of these groundbreaking events. The legal aspect of each of event has remained largely unnoticed and under-researched.

It is important to fill the gap by focusing on the role of constitutions, despite its shortcomings, and international commitments of states using Iran as an example. The 
objective is to bring to the fore the role constitutionalism plays in incentivizing states to enter into international commitments and to comply with their international commitments. More than before, the mutual relationship between constitutionalism and international relations is intertwined because of two main developments: a. for better or worse, international relations have become increasingly judicialized, meaning all aspects of inter-state interactions are now subject to some normative regimes; b. more than ever, states feel the need to structure their domestic and inter-state relationship by resorting to a normative structure which is best materialized in constitutions.

Using Iran as an example, this dissertation aims to fulfill the following: First, it is critical to understand whether a state is a constitutional state and whether its domestic power relations are subject to any checks and balances (broadly speaking). By reviewing Iran's recent history through this lens, the dissertation shows that Iranian's legal culture presents (a version of) constitutionalism.

Second, it is critical to understand whether constitutionalism leads to any differences in the international behavior of such a state. Based on its constitutionalism, Iran's international behavior has been premised on legalistic and juridical grounds. 


\section{TABLE OF CONTENTS}

CHAPTER

PAGE

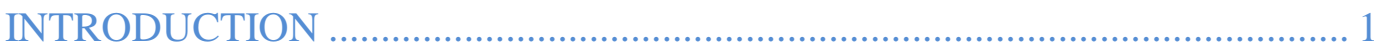

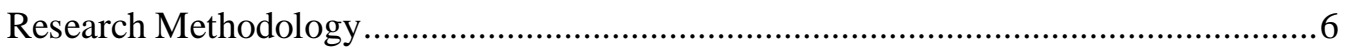

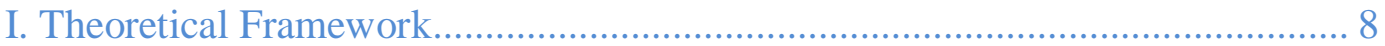

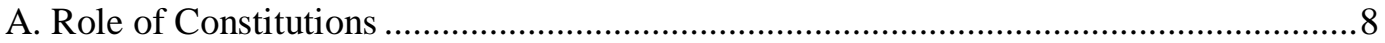

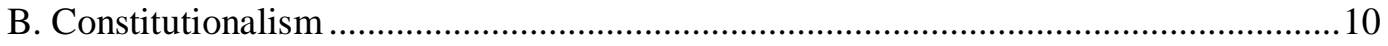

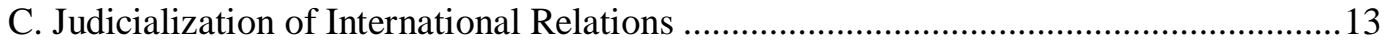

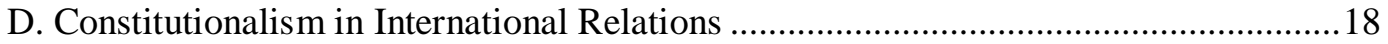

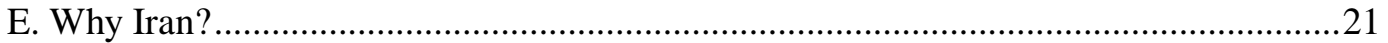

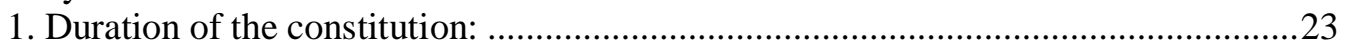

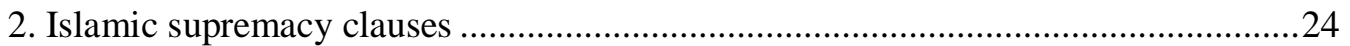

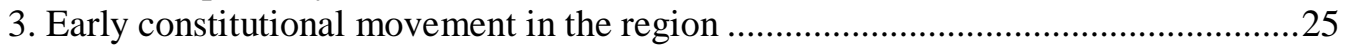

4. New constitutional movements in the region........................................................26

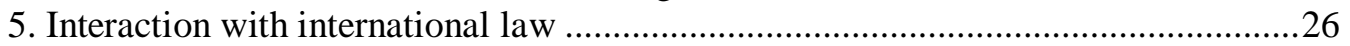

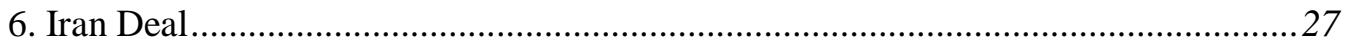

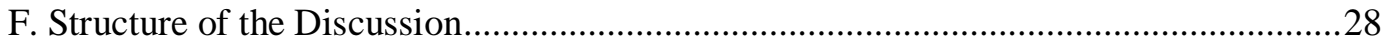

II. Sparking the Flame: Revolution............................................................. 32

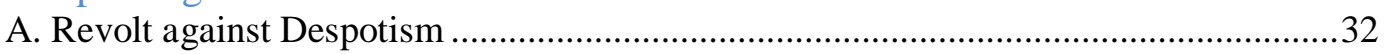

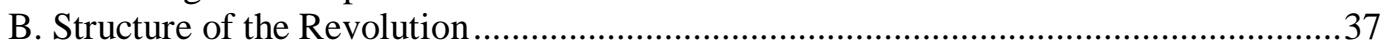

III. Legalizing the Revolution: Drafting ...................................................... 48

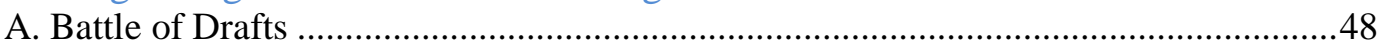

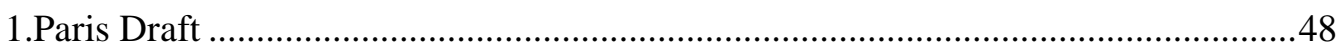

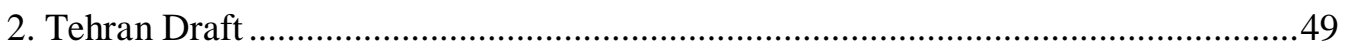

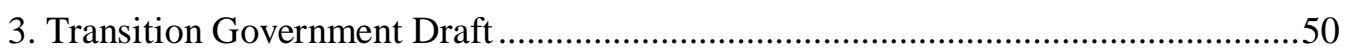

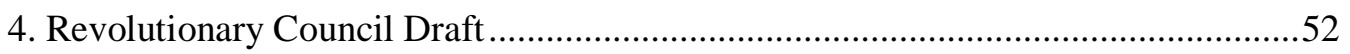

B. The Assembly of Constitutional Experts ................................................................54

IV. Reassurance of Revolutionaries: Establishing ........................................... 64

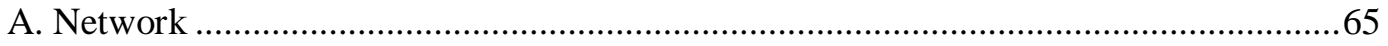

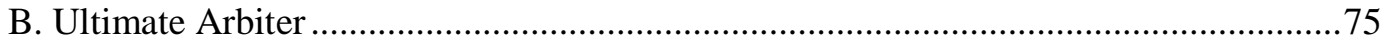

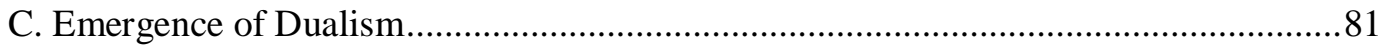

V. End of Charisma: Institutionalizing ....................................................... 89

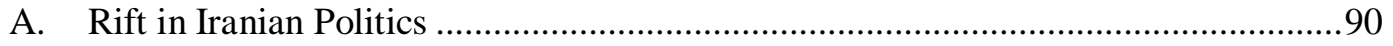

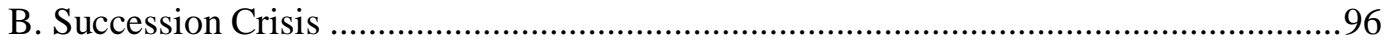

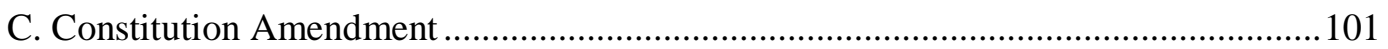

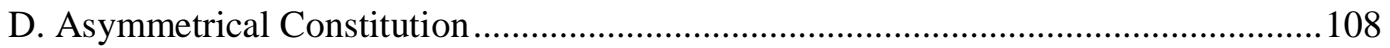

VI. International Agreements as a Balancing Factor ..................................... 110

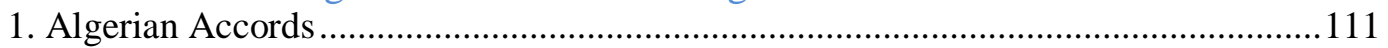

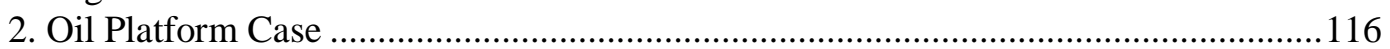

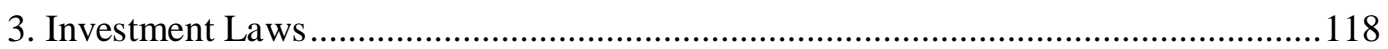

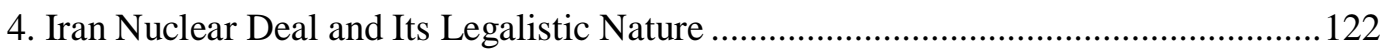

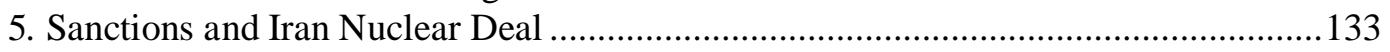

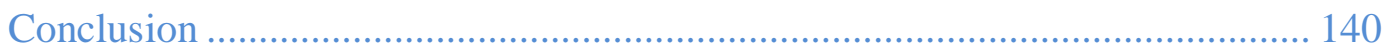




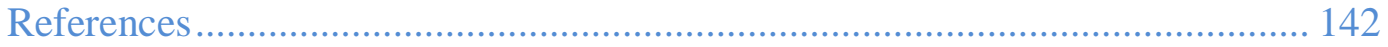

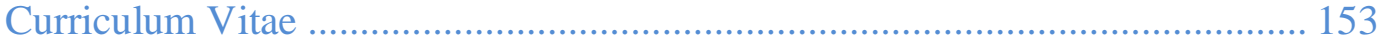




\section{INTRODUCTION}

Constitutions are the most important legal as well as political documents in the majority of states. Following mass atrocities of the $20^{\text {th }}$ century, constitutions have been viewed as documents that can protect certain minimal civil and political rights and regulate the power dynamics within a polity. In the inter-state relationship, constitutions have served as a signal to demonstrate 'statehood' and to establish autonomy. Despite its importance, constitutions and in particular constitutionalism, have not been analyzed in international relations and international law.

International relations as a field has been primarily preoccupied with 'order' or lack thereof in the international arena, role of material power, and liberal values such as democracy. International law as a field, on the other hand, has viewed constitutions as either determinant of 'decision-makers' in each political system or a domestic law instrument that could play a role in international law disputes. There is little discussion on the inter-play between constitutionalism on the one hand and international relations.

It is important to fill the gap by focusing on the role of constitutions, despite its shortcomings, and international commitments of states using Iran as an example. The objective is to bring to the fore the role constitutionalism plays in incentivizing states to enter into international commitments and to comply with their international commitments. More than before, the mutual relationship between constitutionalism and international relations is intertwined because of two main developments: a. for better or 
worse, international relations have become increasingly judicialized, meaning all aspects of inter-state interactions are now subject to some normative regimes; b. more than ever, states feel the need to structure their domestic and inter-state relationship by resorting to a normative structure which is best materialized in constitutions.

Using Iran as an example, this dissertation aims to fulfill the following: First, it is critical to understand whether a state is a constitutional state and whether its domestic power relations are subject to any checks and balances (broadly speaking). By reviewing Iran's recent history through this lens, the dissertation shows that Iranian's legal culture presents (a version of) constitutionalism.

Second, it is critical to understand whether constitutionalism leads to any differences in the international behavior of such a state. Based on its constitutionalism, Iran's international behavior has been premised on legalistic and juridical grounds.

As will be discussed below, the formation of Iran's Constitution and its underlying historical development paved the way for a binary "power struggle" between the presidency and the supreme leader position. Unlike judicial checks and balances that create and safeguard constitutional norms, Iran's judiciary has rarely played a significant role in solidifying the constitutional norms. On the other hand, however, due to a rift created in the Constitution this role has been primarily vested and exercised by this rift with the president being the advocate for the Constitution and the constitutional norms. This is further reinforced by an ingrained legalistic culture in Iran based on pre-Islamic Zoroastrianism as well as Shiite jurisprudence. 
For example, one of the ingrained and highly cited principles under Shiite jurisprudence is that one should abide by one's legal commitments. ${ }^{1}$ The notion of honor based on keeping one's promise is also important in Iranian culture. Iranian "cultural milieu" has in its roots the idea that "one keeps promises and expects others, especially those known to have great public status and claims of greatness to 'do the right thing', 'be honorable', 'upright', and 'a man of your word'; a 'pre-liberal' culture of 'honor' and 'chivalry', especially when promises and signals of good intentions and reciprocity are made, either in public, or clearly in private."2

Historical examples also demonstrate us that constitutions played a pivotal role in the legitimization and/or de-legitimization of governments. A few notable examples are:

1) Iran is home to the first Constitutionalist movement in the region. From 1905-1911, Iran underwent an uprising with the main message of making the long tradition of monarchy in Iran constitutional. Establishing the rule of law and constitutionalism were indeed the main demands of the people:

"Inspired by Western ideas, it believed that the country could rapidly progress if the arbitrary will of kings was replaced with the predictable rule of laws, the power of dynasties with the authority of elected representatives, the traditional art of communal

1 The Principle of Binding Nature of Contracts, available at http://wikifeqh.ir/قزوم_قاعده

2 Mohiaddin Mesbahi, Trust and U.S.-Iran Relations: Between the Prisoners' Dilemma and the Assurance Game, 4 IRANIAN REV. OF ForEIGN AFFAIRS, 7, 31 (2013). 
manipulation with the modern science of social engineering. In short, the intelligentsia wanted to supplant Oriental despotism with Western constitutionalism."3

2) Constitutional values for which the Constitutional Revolution was fought soon were undermined by the monarchy of Reza Pahlavi. ${ }^{4}$ Once again with the rise of a democratic government in the 1950s (albeit short-lived), values of the constitution and rule of law were emphasized. Mohammad Mosadegh who became the Prime Minister of Iran from 1951-1953 in a democratically elected process tried to revive the constitutional values. As noted by the Iranian historian, Ervand Abrahamian, "Mosadegh in his speeches from 1320 [1940-1941] until his battle for nationalization of oil, was more preoccupied with increase of people's participation in politics, reform of election process, and the role of King in the politics." 5

3) During its battle with the Shah, Khomeini invoked the 1906 Iranian Constitutionwhich was enacted as a result of the Iranian Constitutional Revolution - to delegitimize Shah's governance and government. Khomeini was fond of a provision in the 1906 Constitution allowing for religion clerics to review laws based on their correspondence

3 Ervand Abrahamian, The Causes of the Constitutional Revolution in Iran, 10 INT'L J. OF MIDDLE EAST STUDIES 381, 412 (1979)

4 Arguably Reza Pahlavi's government was not unconstitutional. "Analytically, Reza Shah's rule in 1920 's although growingly dictatorial, was not yet unconstitutional. The point is fine, though very important, and so it needs a short explanation. Any dictatorship was certainly contrary to the constitution of 1906 and its supplements, as it was a basically democratic constitution. On the other hand, constitutional - as opposed to arbitrary - rule does not necessarily have to be democratic. Therefore, authoritarian or dictatorial governments, although obviously undemocratic, are not unconstitutional... This is what Reza Sha;s rule looked like at the beginning..." HOMA KatouZian, State AND SOCIETY In IRAN: THE ECLIPSE OF THE QAJARS AND THE EMERGENCE OF THE PAHLAVIS 314 (2006).

5 Yervand Abrahamian, Mosadegh valued constitutionalization of Monarchy as much as he valued nationalization of oil, 24 March 2012 available at

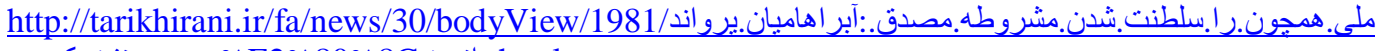

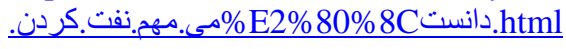


with Islamic laws. ${ }^{6}$ But, Khomeini also used the 1906 constitution to attack the Shah's Government for its non-compliance with the constitution including for personal freedom. Khomeini once said in one of his speeches addressing Shah: "if you are relying on the constitution, the constitution is saying that you should free the people. . . it prohibits from cruelty. We say you should abide by the constitution. . .the constitution has freedom of press, will you allow the press to be free? Is it us who are reactionary in that we say you should abide by the constitution." 7

Historically, the ruling class and even the judiciary often flouted the texts of the constitutions. But it was always viewed as aberrant from the norm to do so. It is often referenced in the political discourse that certain behavior is against the constitution. For example, Mohammad Khatami in 2001 warned the head of Iran's judiciary that by trying members of parliament it was violating the constitution. He issued a warning and asserted that "I stated to the judiciary chief that the president, according to the Constitution, is the second supreme official of the country. . .I announced that the

One of the hallmarks of the Constitutional Revolution of Iran was the execution of the renowned and prominent clergy, Sheihk Fazlolah Noori by the revolutionaries. He was one of the opponents of the Revolution asserting that the laws of the land should be compatible with Islamic Law. He suggested that a group of jurists scrutinize the laws passed by the parliament to ensure that they conform to Islamic rules and standards. Despite the execution of Fazlolah Noori, his idea entered the Constitution as an amendment. More than 50 years later, this idea was reincarnated in the idea of the Guardian Council in the 1979 Iranian Constitution in emulation of Conseil Constitutionnel from the French Constitution of the fifth republic. This provision, along with Article 4 (Islamic Supremacy Clause) and Article 5 (Clergy's Guardianship) of the Constitution became the landmarks of the Islamic Republic of Iran Constitution.

7 What was Imam Khomeini's opinions regarding the 1906 constitution? Imamkhomeini.ir available at http://www.imam-khomeini.ir/fa/n20644/ بود؟ جه مشروطه اساسى قانون_ى درباره خمينى امام_ديدكاه 
president, besides being the head of state, is responsible for the execution of the Constitution." 8

The focus of this dissertation as it will be explained is the post-1979 Revolution, the period in which the new constitution and constitutionalism were being formed and developed. The impact of such constitutionalism can be traced in Iran's approach to its international commitments.

\section{Research Methodology}

In order to conduct the underlying research for this dissertation, I used the primary sources available in Iran, online, and at major universities in the United States:

- $\quad$ During several trips to Iran between 2014-2015 I reviewed and collected legal sources discussing the Iranian Constitution. Even though major Iranian professors such as Dr. Nasser Katouzian have written on the Iran's constitution, the literature in Farsi on constitutionalism - the impact of the constitution in Iran's legal culture - is sparse. This is further reinforced by the fact that courts typically do not invoke the Iranian Constitution in their dispute resolution function-unlike other countries such as the United States - and Iran does not have a Constitutional court. Lawyers and legal academics, therefore, do not put the focus on of their discussion on Iran's Constitution. 
- I also reviewed and collected sources at major U.S. universities. I visited the Farsi sources at Yale University from 2013-2014 and Stanford University during the summer of 2014 .

- I also consulted online sources available on the topic, most importantly, the detailed discussion of the Assembly of Experts which ultimately finalized and proposed the Iranian Constitution for referendum. ${ }^{9}$

- I also interviewed Iranian historians such as Dr. Abbas Milani at Stanford University, U.S. constitutional scholars such as Yale's Bruce Ackerman. (Mr. Ackerman later supervised the constitutional aspect of the project) and experts on rule of law such as Stanford's Erik Jensen.

- I presented this topic (and related topics) at several conferences including Yale Law and Religion Debate Series and Stanford Law and Society in 2016.

9 See Detail Discussion on Final Review of the Islamic Republic of Iran Constitution, available at http://www.majlesekhobregan.ir/fa/MashroheMozakerat.html 


\section{Theoretical Framework}

\section{A. Role of Constitutions}

Constitutions are generally perceived as the most important legal document for a polity. The functions and roles of a constitution are manifold. The constitution aims to coordinate (and limit) the power struggle between various leadership positions of the ruling body (horizontal function). In other words, it constrains the power and authority of those who are in power vis-à-vis each other. It also aims to regulate the relationship between the rulers and citizens of a certain polity (vertical function). The horizontal function concerns the institutions of a certain polity and their respective structures and duties. For instance, it establishes governmental institutions such as legislature, executives, and the judiciary and defines their respective scope of authority and procedures. The vertical function sets the role of citizens, their rights, and methods of participation in the polity. Through this function, the constitution delineates the scope of 
citizen participation in a polity through elections or other means. It also lays out the individual rights of citizens in the polity and in relation to the government and the abuse of power.

Constitutions also promise to offer normative functions as well. As the founding document, constitutions provide foundational norms by which "other lower-order legal norms are to be produced, applied, enforced, and interpreted." ${ }^{10}$ These foundational norms are purported to generate other norms in a certain polity. Through the normgenerative function, three goals are achieved: 1) constitutions reduce the collective action problem 2) constitutions provide predictability and reliance 3) constitutions create a sense of identity and continuity. Through establishing fundamental norms, constitutions aim to alleviate the problem of free riding in a political order by constraining the self-interest and interest-driven objectives of political actors. ${ }^{11}$ Constitutions also create predictability in political orders by creating a hierarchical structure by which officials can interact with each other and states can enter into international relations. The leaders that represent states emerge as a result of a normative and hierarchical structure generated by constitutions and/or other similar foundational documents. Lastly, and more importantly for our discussion, constitutions create a sense of "belonging" to a certain polity. Disagreements about the nature and scope of constitutions exist. ${ }^{12}$ Yet, constitutions aim

10 Alec Stone Sweet, Constitutionalism, Legal Pluralism, and International Regimes, 16 IND. J. Global LEGAL StUd. 621, 626 (2009).

11 Alec Stone Sweet, What is a Supranational Constitution? An Essay in International Relations Theory, 56 THE REV. OF POLITICS, 441, 443 (1994).

12 "Not only is the list of fundamental constitutional norms open to debate, but the very identity of "the Constitution" - the body of textual and historical materials from which the norms are to be extracted and by which their application is to be guided-is itself a matter that cannot be 
to create an identity (or several close identities) to which most of the political actors and citizens relate. The identity comes to fruition despite disagreements amongst actors and citizens. ${ }^{13}$ In summary, using the language of Noah Feldman, constitutions provide "grand philosophical principles that underlie the very existence of the political order."14 Or, to put it differently, constitutions have the potential to offer a set of narratives through which different actors - both inside and outside of the political order-relate to the polity.

\section{B. Constitutionalism}

Constitutionalism has become one of the evasive notions in the legal and political literature. This term has gained further popularity particularly in conjunction with the "global constitutionalism" agenda put forward by a group of scholars. ${ }^{15}$ Alec Stone Sweet defines constitutionalism as "...the commitment on the part of any given political

objectively deduced or passively discerned in a viewpoint-free way." Lawrence Tribe, A Constitution We are Amending: In Defense of a Restrained Judicial Role, 97 HARV. L. REV. 443, 440 (1983).

13 “...constitutional disharmony is critical to the development of constitutional identity, even as it may take more challenging task of establishing the specific substance of that identity at any given point in time.”, GARY J. JACOBSOHN, CONSTITUTIONAL IDENTITY 4 (2010)

14 Noah Feldman, Islamic Constitutionalism in Context: A Typology and a Warning, 7 U. ST. THOMAS L. J. 436, 443 (2010).

15 The term global constitutionalism is also vague. Some define it as emergence of constitutional law methodology and approaches in international law, Anne Peters, The Merits of Global Constitutionalism. 16 InD. J. Global Legal StUd, 397, 397 (2009). Other refer to the unification of constitutional practice and drafting in today's world, David Law \& Mila Versteeg, The Evolution and Ideology of Global Constitutionalism, 99 CAL. L. REV. 1163, 1163 (2011). Yale Law School has a Global Constitutionalism Seminar in order to "create an international rule of law, in which justice can flourish in peace.", http://www.law.yale.edu/intellectuallife/globalconstitutionalismseminar.htm. 
community to be governed by constitutional rules and principles." ${ }^{16}$ Bruce Ackerman has a simpler approach. He defines constitutionalism as actual (not merely based on the wording of the constitution) constraints of power relations in a state. ${ }^{17}$ Moreover, Ackerman posits that constitutions present a legitimacy narrative to the authority of states. Weber famously asserted that authority gains legitimacy through one or more of the following factors: tradition, charisma, or bureaucratic rationality. Ackerman's goal is to add a more relevant and important item to the list. In today's world, constitutions grant legitimacy to a political order. ${ }^{18}$ The perception of actors in a certain political order regarding the legitimacy narrative is paramount in the political life of that polity. In the language of Ackerman, "the presence or absence of a widespread belief in constitutional legitimacy can play an important-sometimes, all-important-role in shaping political life." 19

As a result, constitutionalism has two major components:

1) paradigmatic element;

2) practical element.

With the first factor, I refer to the normative function of a constitution in a certain polity by which citizens' and political actors' ideas about the polity converge (or even diverge) as a result of constitutional norms. This is a mental and belief-based element that can

16 Stone Sweet, supra note 10 at 626.

17 World Constitutionalism, Manuscript is with the author

$18 I d$.

$19 \quad I d$. at 4. 
guide us to the viability of constitutionalism in a certain polity. For instance, lack of reference or debate regarding the constitution can demonstrate weak constitutionalism. In other words, even strong disagreement on certain issues of the constitution by political actors and citizens shows a level of constitutionalism in a political order. The other element of constitutionalism is the practical factor. With this factor, I refer to the actual and historical facts showing that the constitution has limited the authority of those who govern. This shows that the constitution is more than a piece of paper in the polity under study. Not only do actors refer to the constitution in the political culture and paradigm but they are also constrained by its institutional and legal design.

It is crucial that we draw a distinction between constitutionalism and the rule of law and democracy. The discussion of rule of law briefly investigates the existence of positive laws in each legal system, their ubiquitous application and citizens' compliance with it. Constitutionalism, on the other hand, probes into the constraints that exist for people in power. An example can illuminate this idea: Imagine a person who holds a political post, let's say the secretary of state, commits a gruesome act of domestic violence against his spouse. In this case, the gauge for the rule of law is to observe whether the law applies to the accused person as it is applied to other citizens. In the same scenario, if the parliament impeaches the same person due to his domestic violence accusations, we are confronting an element of constitutionalism. The rule of law and constitutionalism are inevitably 
intertwined. ${ }^{20}$ Yet, the distinction is critical in understating different levels of constraints imposed by law especially in the context of developing countries.

Constitutionalism is also invariably different from a democracy. At the expense of oversimplification, democracy can be defined as a method of government by which citizens select the ruling elites through an electoral process. ${ }^{21}$ Constitutionalism, however, refers to the adherence of most political actors and citizens to the political order as designed by the constitution. A democratic government can be a result of constitutionalism and constitutionalism can ensue a democratic movement. Yet, these two notions are independent.

\section{Judicialization of International Relations}

The scene of international relations is changing. The most important factor that is shaping the change in our contemporary world is the "judicialization" of international relations. The traditional view in international relations, the so-called realist view, emphasizes the importance of the hard power of states in the anarchical setting of international relations. ${ }^{22}$ In summary, in an international setting with no centralized government,

20 "Constitutionalism is also premised on the rule of law as opposed to the rules of everyday men and women. A constitution places a higher law above the policies and practices of transient leaders or ruling majorities, and it requires that they abide by that constitutional higher law." JAMES CURRY ET AL, CONSTITUTIONAL GOVERNMENT: THE AMERICAN EXPERIENCE 6 (2003).

21 For instance, we can look at the definition of Lipset and Lakin which is inspired by Joseph Schumpeter, "The minimal definition of democracy we prefer is an institutional arrangement in which all adult individuals have the power to vote, through free and fair competitive elections, for their chief executive and national legislature.", SEYMOUR LIPSET \& JASON LAKIN, THE DEMOCRATIC CENTURY 19 (2004).

22 The founding fathers of classical realism in international relations are E.H. Carr and Hans Morgenthau. See generally Hans Morgenthau and Kenneth Thompson, Politics Among NATIONS (McGraw-Hill, 6th ed.1985) (1948)" E.H. CARR, ThE TwENTY YeARS' CRISIS 19191939, 166 (Palgrave 2001) (1964); Realism has brought into a new level and has been 
survival becomes the main objective of states; a concern that could merely be alleviated by having strong, hard and militarized power. ${ }^{23}$ For realists, therefore, no real legal constraints exist at the international level and states do not hesitate to break their legal arrangements countering their interests. ${ }^{24}$

Yet, the increasing judicialization of international relations as well as the unprecedented level of legal arrangements in bilateral or multilateral forms between states poses serious questions to the viability of the realist model. For those who believe in anarchic international politics in which states only pursue self-help, it is still baffling to observe that states commit to certain legal arrangements and often abide by them. ${ }^{25}$

Regime theory emerged as one of the first theoretical responses to this phenomenon. According to this theory, states' behavior is shaped and changed pursuant to legal regimes. ${ }^{26}$ Stephen Krasner suggested a definition of regimes that now serves as the structuralized by Kenneth Waltz: Kenneth Waltz, Man, the STAte, AND the War (Columbia University Press, 2001) (1959).

23 With the increasing criticism of realism, its proponents developed a theory of protection using game theory. They posit that in a world with no central authority, cooperation emerges out of rational "tit-for-tat" logic created out of long-term exposures and interactions of states, ROBERT M. AXELROD, THE EVOLUTION OF COOPERATION 60-63 (1984).

24 E.H Carr famously stated that the quality of law rests in its capability to bring stability without which no political and social life is possible. Law's special stature in today's society is not due to its subject-matter or its ethical dimension. However, society cannot survive with law alone. He continues to stress the superiority of politics over law: "the ultimate authority of law derives from politics." E.H. CARR, supra note 22 at, 166.

25 Judith Goldstein et al, Introduction: Legalization and World Politics, 54 INT'L Org. 385, 391 (2000). On the other hand some scholars have tried to show that the role of realism in international law has been downplayed and realism indeed served as a theoretical base for several developments in international law, Richard H. Steinberg, Wanted-Dead or Alive: Realism in International Law in INTERDISCIPLINARY PERSPECTIVE ON INTERNATIONAL LAW AND INTERNATIONAL RELATIONS 146, 146-148 (2013).

26 Stephen Krasner, Structural Causes and Regime Consequences: Regimes as Intervening Variables in INTERNATIONAL REGIMES 1,1 (1983). 
classical approach for regimes: "regimes can be defined as sets of implicit or explicit principles, norms, rules, and decision-making procedures around which actors' expectations converge in a given area of international relations." ${ }^{27}$ These regimes morph actors' exceptions and behaviors independently from the power dynamics of international relations. ${ }^{28}$ Robert Keohane, another prominent regime theorist, noted that international regimes perform valuable functions including reducing transaction costs, facilitating negotiations and attaining mutual agreements between states via allowing certain types of bargaining. ${ }^{29}$

Yet, the rational and functional account of international cooperation suffers from two main shortcomings: It is highly difficult to measure both the costs incurred on states as a result of cooperation and the benefits they gain from it. International investment law serves as an illuminating example where studies deliver contradictory results on the benefits states receive from participating in the investment regime. ${ }^{30}$ In order to attract foreign investment, states signs treaties that are not clear have any impact on bringing in foreign investment.

Furthermore, the rational / functional account international cooperation fails to account entirely for situations where states continue to partake in regimes even after they cease to

$27 \quad I d$. at 2.

$28 I d$. at 10.

29 Robert KeOHANe, After Hegemony: COOPERATION AND Discord IN THE WORLd POLITICAL ECONOMY 107 (1984). For a similar functional account on the way international organizations work through centralization and independence, see Kenneth Abbott \& Duncan Snidal, Why States Act Through Formal International Organizations 42 J. ConfLICT RESOL. 3, 9-23 (1998).

30 Andrew Guzman, Why LDCs Sign Treaties that Hurt Them: Explaining the Popularity of Bilateral Investment Treaties, 38 VIRGINIA J. INT’L L. 639 (1998). 
benefit them. The Non-Proliferation Treaty regime serves as a good example for countries, such as Iran, that never withdrew from the treaty, even after the costs seems to have surpassed its benefits. ${ }^{31}$

Another school has tried to explain the judicialization in international relations by employing a transnational approach. This is commonly referred to as the liberal school of thought. ${ }^{32}$ Through the scholarly works of Moravcsik, Slaughter, Keohane and others, a transnational explanation of states' behavior has been put forward. ${ }^{33}$ Briefly, this school emphasizes the role of domestic actors and politics and their influence on the international behavior of states. Unlike other international relations theories, as Moravcsik argues, the liberal theory endeavors to furnish a systemic account of international cooperation, which includes the dynamics of domestic politics. ${ }^{34}$ This approach has its roots in Peter Haas' theory of 'epistemic community' ${ }^{35}$, Robert Keohane and Joseph Nye's theory of 'complex interdependence' 36 as well as Robert Putnam's idea

31 Francois Nicoullaud, Iran's NPT Withdrawal Option, LOBE LOG, 12 January 2015.

32 Judith Goldstein et al, supra note 25 at 392.

$33 \quad I d$.

34 Andrew Moravcsik, Integrating International and Domestic Theories of International Bargaining in Double-edge Diplomacy: International Bargaining and Domestic Politics 3, 7-9 (Peter Evans et al eds.,1993). Moravcsik provides examples of north-south relationship to buttress his view point: 1) Carter human rights policy in Argentina and Guatemala, 2) US policies towards Panama and Nicaragua 3) International Monetary Fund stabilization agreements in Jamaica and Somalia, $I d$. at 20.

35 "Between international structures and human volition lies interpretation. Before choices involving cooperation can be made, circumstances must be assessed and interests identified. In this regard, to study the ideas of epistemic communities and their impact on policymaking is to immerse oneself in the inner world of international relations theory and to erase the artificial boundaries between international and domestic politics so that the dynamics between structure and choice can be illuminated.", Emmanuel Adler \& Peter M. Haas, Conclusion: Epistemic Communities, World Order, and the Creation of a Reflective Research Program, 46 INT'L ORG. 367, 367 (1992). 
of a 'two-level game' ${ }^{37}$ among others. All of these theories attempt to interject elements such as transnationalism, institutionalism as well as systemic implications for domestic politics. Recent theories have leaned to deliver what could be called a 'network account' of regulations and norms and their effects on states behavior and international relations. ${ }^{38}$

In all recent intellectual endeavors regarding international relations two developments are noticeable: 1) the increasing importance of norms in shaping states behavior as well as the international sphere; 2) the unprecedented and increasing process for the judicialization and constitutionlization of international relations. In other words, new practical and theoretical developments have "legalized" international relations.

On the status of international relations today, we can echo what critical thinkers have asserted about capitalism. They believe "capitalism is fundamentally a legal ordering: the bargains at the heart of capitalism are product of law." ${ }^{39}$ International relations have become a legal ordering by which state interactions are defined, confined, and enabled by

36 "Complex interdependence, by contrast, is an ideal type of international system, deliberately constructed to contrast with a "realist" ideal type that we outlined on the basis of realist assumptions about the nature of international politics. Complex interdependence refers to a situation among a number of countries in which multiple channels of contact connect societies (that is, states do not monopolize these contacts); there is not hierarchy of issues; and military force is not used by governments towards one another." Robert O. Keohane \& Joseph S. Nyle, Power and Interdependence Revisited, 41 INT'L ORG. 725, 731 (1987).

37 "Unlike state-centric theories, the two-level approach recognizes the inevitability of domestic conflict about what the "national interest" requires. Unlike the "Second Image" or the "Second Image Reversed," the two-level approach recognizes that central decision-makers strive to reconcile domestic and international imperative simultaneously." Robert D. Putnam, Diplomacy and Domestic Politics, The Logic of Two-Level Games, 42 InT'L ORG. 427, 460 (1988).

38 Anne-Marie Slaughter, supra note at 51; David Grewal, Network Power: the Social DYNAMICS OF GLOBALIZATION 247-258 (2008)

39 David Grewal, Book Review: The Laws of Capitalism by Thomas Piketty, 128 HARV. L. ReV. 626, 652 (2014). 
a legal ordering. The very basic unit of international relations, states, is a legal product (through social contract, constitution, etc.).

We can even push the needle a bit further: power relations, the most fundamental feature of international relations, are legal relations. Military capabilities cannot translate into "hard power" unless they can have an impact on the legal ordering of the opponents through change of constitution (e.g. Iraq), ratification of a treaty (e.g. Treaty of Versailles), or creation of an international tribunal (e.g. International Criminal Tribunal for the Former Yugoslavia) and so on. It is as if the ultimate power is to have legal jurisdiction - not physical power — over the opponent. That's reminiscent of "[ $t]$ he supreme art of war" according to Sun Tzu, which "is to subdue the enemy without fighting." 40

\section{Constitutionalism in International Relations}

As a legal and political unit, it is imperative to understand the role of constitutionalism in international relations and international law. Liberal theories have asserted that domestic politics and the structure of states determine states' behavior at the international level. ${ }^{41}$ Yet, they have focused on the liberal elements of states. The liberal camp, for instance, have emphasized factors such as civil and political rights, separation of powers, a functional judiciary system, rule of law, and democracy. As a result, "these particular features of domestic political structure are important determinants of the interaction

40 SUN TZU, THE ART OF WAR.

41 Anne-Marie Slaughter, International Law in a World of Liberal States, 6 EUR. J. INT'L L. 503, 537 (1995). 
between the State and individual and group actors in domestic and transnational society." 42 The theory of democratic peace is a case in point. The focus of the study is on "democracy" as a critical element in liberal democracy and its role in peacemaking in international relations. This theory argues "liberal states, founded on such individual rights as equality before the law, free speech and other civil liberties, private property, and elected representation are fundamentally against war..."43 As this synopsis of the theory shows us "liberal values" have been at the center of liberal theories in international relations.

Much less discussed, however, is the issue of constitutionalism. As discussed, constitutionalism is independent of liberal values such as the rule of law and democracy. This notion, as set out earlier, focuses on the constraints of power relations between political actors. The states' constitutions do not have to be liberal constitutions. In this sense, constitutions create a sense of unity that political actors take into account in their decisions. As a result the constitutionalism of states affect states' behavior. On the other hand, international relations also affect the constitutionalism of states and the way political actors perceive their roles in a political order. As a result, the discussion of constitutionalism in international relations can fill the void in the literature that has focused on liberal values.

The role of constitutionalism also can help us understand the perennial question in international law and international relations as well: why do nations obey international

$42 \quad I d$. at 511.

43 Michael W. Doyle, Liberalism and World Politics, 80 AM. PoL. SCI. ReV. 1551, 1551 (1986). 
law? There have been several waves of responses to this question: realists deny it, liberals look into the states' political systems for answers, some international law schools of thought ${ }^{44}$ point to decision-makers, rationalists (law and economics) refer to a costbenefit analysis of compliance, and transnationalists argue that through an internalization process norms of international law penetrate into domestic legal systems. ${ }^{45}$

The prevailing literature, however, does not look into the role of international law as an exogenous element (the Other) in which states see themselves and their political order. To put it differently, states find their constitutional identity through their interaction with international law. It is similar to Cynthia Weber's argument about intervention and sovereignty. She claims "intervention practices participate in stabilizing the meaning of sovereignty. ${ }^{" 46}$ This is because the intervention discourse requires, a priori, a normative structure, i.e. sovereignty, that should be intervened. ${ }^{47}$ For the same matter, participation in international law requires, a priori, a legal ordering independent of international law. As a result, states retroactively obtain the status of independence by participating in international law, which retrospectively shapes their constitutional and political order.

44 See e.g. Myres McDougal \& Harold Lasswell, The Identification and Appraisal of Diverse Systems of Public Order, 53 AM. J. INT'L L. 1, 9 (1959) (“our chief interest is in the legal process, by which we mean the making of authoritative and controlling decisions."); see also Michael Reisman, International Law-making: A Process of Communication, 75 AM. SOC'Y InT'L L. ProC. 101,113 (legal process consists of "policy content, authority signal and control intention.”)

45 See generally, Harold Koh, Review Essay: Why do Nations Obey International Law? 106 YALE L. J. 2599 (1996).

46 Cynthia Weber, Simulating Sovereignty: Intervention, the State and Symbolic CHANGE 4 (2001)

$47 \quad I d$. 
In summary, the discussion of constitutionalism enriches the literature of international law compliance by showing that states obey international law to hold their constitutional order and identity together.

\section{E. Why Iran?}

It is now pervasive that popular movements, if successful, nail their colors to the mast by ratifying a constitution. In fact, paradigmatically, constitutions function as a legitimacygiver to popular movements. We all have witnessed the constitutional efforts of the recent, so-called, Arab Spring. Even before that, in the cases of Afghanistan and Iraqevidently not cases of popular movement but foreign intervention-constitution drafting acted to legitimize the new political order. In all these constitutional maneuvers, two schools of constitutions were identified in the Middle East region: the Turkish model and the Iranian model. ${ }^{48}$ This piece attempts to provide a fresh look at the Iranian Model. Scholars in the West have identified the Iranian model as an Islamic Theocracy. ${ }^{49}$ Politicians, such as Hilary Clinton, warned about the militarization of the Iranian Government. ${ }^{50}$ Conservatives have repeatedly dubbed the Iranian model as

48 See e.g. Mustafa Aykol, Turkey vs. Iran: The Regional Battle for Hearts and Minds, FOREIGN AFFAIRS, Mar. 21, 2012, available at http://www.foreignaffairs.com/articles/137343/mustafaakyol/turkey-vs-iran

"Prior to the revolution in Iran, the conventional wisdom portrayed religion as a dying and anachronistic force whose appropriate place was in history books. In utter defiance of that flawed paradigm, the Shi'I ulama... became the "philosopher kings" of a new theocracy founded on the doctrine of Velayat-e Faqih or the ulama's direct rule.” MOHSEN MILANI, THE MAKING OF IRAN'S ISLAMIC REVOLUTION 2 (Westview Press, 1994).

50 James Strucke, Hilary Clinton: 'Iran is moving toward a military dictatorship', THE GUARDIAN, Feb. 15th, 2010. 
fundamentalist and a promoter of terrorism. ${ }^{51}$ Yet, none of these tags best describes the nuances and complexities of constitutionalism in Iran.

One of the widely misconceived and yet understudied constitutional movements in the Middle East belongs to Iran. ${ }^{52}$ A new perspective on the trajectory of constitutionalism in Iran would better equip us to comprehend rule of law and constitutionalism in the Middle East. From the 1905 Constitutional movement to the 1979 Revolution, Iran has undergone major changes. Each transformation created a rupture with the preceding order fostering a fresh look at rule of law in Iran. The current studies have mainly concentrated on the political and social aspects of these groundbreaking events. The legal aspect of each of these events has remained largely unnoticed and under-researched.

In the wake of the recent uprisings in the Middle East, discussions have emerged regarding whether people in the region would choose the Iranian, Turkish or an idiosyncratic model for their future legal order. ${ }^{53}$ Surprisingly, the discussion emerged in a context where these models, in particular the Iranian model, were largely misunderstood. The Iranian model was presented primarily as a theocratic Islamic regime

51 See e.g. "Iran is central to fundamentalism: its current Islamic Republic became a model for fundamentalists elsewhere and the genesis of its revolution shows starkly the social strains that can encourage a fundamentalist response.", STEVE BRUCE, FUNDAMENTALISM 46 (2008).

52 For a discussion on constitutionalism in Islam, see Raja Bahlul, Is Constitutionalism Compatible with Islam? in THE RULE OF LAW HISTORY, THEORY AND CRITICISM, 515, 515 (2007).

53 See e.g. Meliha Benli Altunisik, The Turkish Model and Democratization in the Middle East, 27 ARAB STUD. Q. 45 (2005); Peter Jones, Arab Spring: Opportunities and Implications, 67 INT'L J 447 (2011); Seyla Benhabib, The Arab Spring: Religion, revolution and the public sphere, EUROZINE (May 10, 2011), available at: http://www. eurozine. com/articles/2011-05-10-benhabiben; Asli Bâli, A Turkish Model for the Arab Spring?. 3 MiddLE EAST L. AND Govern. 1 (2011): 1-2. Some scholars have discussed the Lebanese model too, see e.g. Asli Bali \& Bernard Haykel, Can Turkey or Lebanon be Models for a New Arab Political Order? Debating Law \& Religion Series, Yale Law School, Feb. 4, 2014. 
where rule of law remained suppressed and inferior to the Sharia law with no elements of constitutionalism. Nevertheless, this narrative is distant from the story of constitutionalism and to a certain extent rule of law in Iran. This dissertation aims to present a new and comprehensive view on constitutionalism in Iran with a focus on the Islamic Revolution of 1979 and its aftermath. By no means, do I posit that the Iranian model is a viable option or a desirable model for the people in the Middle East region. I, along with many other scholars,,${ }^{54}$ believe that it is the people of each country that should decide about their political future while designing a special constitutional order of their own. However, the discussions that emerged as a result of the uprisings in the Middle East sparked my interest in exploring what is called the Iranian model. Despite its importance, no major existing constitutional book or treatise has elaborated on the nuances of the Islamic Republic of Iran's constitutionalism. This is going to be a first attempt at describing constitutionalism in Iran.

The story of constitutionalism in Iran includes diverse elements such as religious law, popular movement, revolutionary ideals, charismatic leadership as well as the postcharisma era. There are certain factors that make Iran a critical case to study regarding the effect of constitutionalism in international relations:

\section{Duration of the constitution:}

54 See e.g. Asli Bali \& Bernard Heykal, supra note 6. 
In a seminal work, Elkins, Ginsburg, and Melton analyze the endurance and longevity of national constitutions. They gathered data from every independent state from 1789 to 2005, which included 935 different constitutional systems for more than 200 nation states. ${ }^{55}$ They show that the average lifespan for constitutions is 19 years meaning that most constitutions perish before their 19 th anniversary. ${ }^{56}$ In fact, there are "only a handful" that last longer than fifty years. ${ }^{57}$ Juxtaposing this simple fact with the current Iranian Constitution, we see that the Iranian Constitution has already surpassed the average life span. The Constitution was voted for in 1979 and has endured for roughly 36 years.

\section{Islamic supremacy clauses}

One of the most pressing issues in comparative constitutionalism is related to Islamic supremacy clauses. These clauses aim to structure the political order based on Sharia law. As a result, the question has been whether the constitutions with these clauses conform to liberal and democratic values. ${ }^{58}$ These clauses have either of two forms: 1 ) either they designate Islam as the or a source of law 2) or they stipulate that laws contrary to Islamic Law are void and should be repealed. As a matter of terminology, the former

55 Zachary Elkins et al, The Endurance of National Constitutions 6 (2009).

$56 \quad I d$. at 1.

$57 \quad I d$.

58 Some scholars such as Noah Feldman question this type of enquiry: “...it is necessary to ask whether the focus on liberty in particular in the symposium's title reflected some assumption, unconscious, or otherwise, that Islamic law poses a special threat to the general phenomenon of constitutional liberty, taken to mean something like "the benefits of living in a liberal, constitutional state.", Feldman, supra note 14, at 438. 
clauses are called "Islamic supremacy clauses" and the latter are called "Islamic repugnancy clauses." ${ }^{59}$ Interestingly enough, Iran was the first country to adopt an Islamic supremacy clause in its 1907 constitution. ${ }^{60}$ Henceforth, the Iranian constitution arguably acted as a model for other constitutions, which incorporated such supremacy clauses. ${ }^{61}$

\section{Early constitutional movement in the region}

Iran's constitutional movement in 1906 is one of the earliest movements of its kind in the region. In fact, the preceding constitutions in the region were not sustained by any popular movement except that of Egypt. ${ }^{62}$ Furthermore, the 1861 Constitution of Tunisia, the 1876 Constitution of Ottoman, and the Egyptian Constitution of 1882 did not last long. ${ }^{63}$ Iran's 1907 Constitution, in contrast, came as a result of a popular movement,

59 Dawood Ahmed \& Tom Ginsburg, Constitutional Islamization and Human Rights: The Surprising Origin and Spread of Islamic Supremacy in Constitutions, Public Law and Legal Theory Working Paper No 477, University of Chicago at 7. available at http://chicagounbound.uchicago.edu/cgi/viewcontent.cgi?article=1919\&context=public law and legal theory

$60 \quad I d$. at 1.

61 "It [the repugnancy clause in the Iranian Constitution] bears credit for introducing the very first language of repugnancy that would migrate transnationally into future constitutions.", Id. at 18.

62 Saïd Amir Arjomand, Islam and Constitutionalism since the Nineteenth Century: the Significance and Peculiarities of Iran in ISLAM and CONSTitutional Politics IN THE MidDle East: With SPECIAL REFERENCES TO TURKEy, IRAQ, IRAN AND AFGHANISTAN, 33, 34-35 (2008).

$$
\text { Id. }
$$


which involved both Islamic clerics and non-clerics. ${ }^{64}$ The Iranian Constitution in the language of Amir Arjomand started the second wave of constitutionalism in the region. ${ }^{65}$

\section{New constitutional movements in the region}

The most important constitutional wave in the contemporary era happened in the aftermath of the so-called Arab Spring. In search for constitutional models, many actors repeatedly and vehemently dismissed the Iranian model as an "aspiration for Arabs". ${ }^{66}$ By the Iranian model, they mean a theocratic regime in which Islamic Law dictates all aspects of political and legal order. The Iranian government, on the other hand, rushed to claim that the Arab Spring was Islamic in nature implying that it should follow the path of the Iranian model. ${ }^{67}$ The Iranian model seemed to be perceived as a model that treats Islam as an identity or ideology versus other models such as Turkey or even Pakistan that view Islamic Law as merely a source of law. ${ }^{68}$ The current tension between Iran's constitutionalism and other emerging constitutional orders in the region renders the Iran case unique for examining the transnational impact of constitutionalism.

\section{Interaction with international law}

64 "The Ulama, the official interpreters of the shari'a, had been invited to participate in the drafting of the Tunisian Constitution of 1861, but declined, arguing that it was a political matter and therefore did not concern them.", Id.

$65 \quad I d$.

66 Fatima Ahmad Alsmadi, The 'Iranian Model' is no inspiration for Arabs, Aljazeera, Oct. 5, 2014, http://www.aljazeera.com/indepth/opinion/2014/10/iranian-model-no-inspiration-a2014105101919853679.html

67 Saïd Amir Arjomand, Revolution and Constitution in the Arab World in BEYOND THE ARAB SPRING: THE EVOLVING RULING BARGAIN IN THE MIDDLE EAST 151,165 (2014).

Id. at 166 . 
Interestingly enough, Iran has a long history of engagement and dis-engagement with international law. From the nationalization of oil to the hostage crisis, Iran was actively involved in the development of international law. Iran did not simply dismiss international law and its effects. Instead, it tried to shape it. For instance, one of the early investment tribunals at the international level is the Iran-US Claims Tribunal. It created critical precedents for expropriation, which later became the bedrock and backbone of today's international investment law and arbitration. Despite its contentious relationship with Western countries, Iran never secluded itself from the possibilities of engagement in world affairs through international law.

\section{Iran Deal}

Following months of negotiations, Iran signed a deal with the P5+1 countries to curb its nuclear activates in exchange for an easing of economic sanctions. This Deal is probably the most important arms agreement in the post-Cold War era. Yet, Iran's compliance with its commitments under the deal remains uncertain. As a result, a historical analysis of constitutionalism in Iran and its relations to Iran's international commitment will shed light on the question of Iran's compliance with the Deal. This pressing matter cannot be studied in isolation. To comprehend and predict Iran's future behavior, a robust analysis of its constitutionalism and international commitments is needed.

In summary, this is a first attempt to provide a new and fresh view of the Iranian revolution and its aftermath. In addition to constitutionalism in Iran, this research will help us understand Islam and constitutionalism and the Iranian model of political order. Understanding constitutionalism in Iran will help us comprehend foreign policy as well 
as Iran's international commitments. In other words, there is an inextricable link between the constitutionalism of Iran and its international behavior. This factor is largely neglected when scholars, pundits, and policymakers analyze the behavior of the Islamic Republic of Iran and its international commitments. With the unfolding of the Iran Deal to occur within the next decade or more, it is crucial to have a deep grasp of the interaction between constitutionalism and compliance with international commitments with regards to Iran. The research aims to demonstrate the extent to which constitutionalism has a direct effect on international commitments and vice versa.

\section{F. Structure of the Discussion}

The methods used to study a constitution can vary significantly. One can take a purely textual and linguistic approach. ${ }^{69}$ Another approach is to investigate and extract the original intent of the drafter of the constitution under study. ${ }^{70}$ Some believe in the concept of a living constitution by endorsing a method of contextual interpretation based on the "changing environment" in which we live in. ${ }^{71}$ Others take a hybrid approach and intend to blend originalism with the living constitutionalism method. ${ }^{72}$ However, none of

69 Justice Scalia of the Supreme Court of the United States is famous for his textualist approach to the Constitution, see e.g. Nicholas S. Zeppos, Justice Scalia's Textualism: The "New" New Legal Process, 12 Cardozo L. Rev. 1597 (1990).

70 See e.g. LEONARD W. LEVY, ORIGINAL INTENT AND THE FRAMERS' CONSTITUTION (1988).

71 William H. Rehnquist, The Notion of a Living Constitution, 54 TEX. L. REV. 693, 694 ("The framers of the Constitution wisely spoke in general language and left to succeeding generations the task of applying that language to the unceasingly changing environment in which they live.")

72 JACK BALKIN, LiVING ORIGINALISM 3 (2011). (“The method of text and principle is both originalist and living constitutionalist. It is faithful to the original meaning of the constitutional 
these approaches may be helpful for a meta-analysis (discourse analysis) of a constitution in a developing country with intermittent turmoil and popular uprising tumultuous setting. In other words, these methods guide us through times of normal politics and help us interpret the constitution one way or another. When dealing with a fledgling constitutional order with ebbs and flows and its relevance to the political order, a new method is needed. Normal politics are distinct from constitutional politics. Normal politics refers to times when governments operate with minimal intervention by the people daily political activities. But, "under special constitutions conditions" people's decisions have an impact on normal politics. This is what Professor Ackerman calls “constitutional politics":

"Before gaining the authority to enact its proposal into a nation's higher law, a political movement must, first, convince an extraordinary number of its fellow citizens to take its proposed initiative with a seriousness that they do not normally accord to politics; second allow opponents a fair opportunity to organize their own forces; third, convince a majority of Americans to support transformative initiatives as their merits are discussed, time and again, in the deliberative for a provided by the dualist constitutional order for this purpose. It is only those initiatives that survive this specially onerous higher lawmaking system that earn the special kind of legitimacy the dualist accords to decisions made by the People." 73

text and to its underlying purposes. It is also consistent with a basic law who reach and application evolve over time, a basic law that leaves to each generation the task of how to implement text and principle in their own time.")

73 Bruce Ackerman, Constitutional Politics/Constitutional Law, 99 YALE L. J., 453, 461 (1989): see generally Bruce ACKeRMAN, We the PeOPle: Foundations (1993). See also Bruce Ackerman, 
This approach links a popular movement to constructional changes, termed "constitutional moments". ${ }^{74}$ According to this school, major shifts in constitutional law in the US occurred outside the prescribed method of Article V of the Constitution. It is not "normal politics" that determine and shape constitutional change. It is popular demand and movement that morph most of constitutional change. Ackerman posits that the China and Russia cases are outlier examples in the modern era. Their popular uprisings did not end in constitutionalism. For several decades, those examples have been employed to show that revolutions and popular uprisings do not lead to constitutionalism. This view has been dominant in framing the Iranian revolution, which is thought to follow the tragic fate of constitutionalism in Russia. ${ }^{75}$ This new wave of American Constitutionalism studies can be applied to fledgling constitutional orders such as Iran. Due to a lack of robust institutions for people to interfere with government decisions, constitutional politics is more important in shaping the political order of states such as Iran. In other words, popular movements remain the only way to change the course of constitutionalism.

Constitutional Politics/ Constitutional Law, 99 YAle L. J. 453 (1989); Bruce Ackerman, The Storrs Lectures: Discovering the Constitution, 93 YALE L. J. 1013 (1984).

74 There is rampant discussion on the topic of constitutional moments, see e.g. Michael Klarman, Constitutional fact/Constitutional Fiction: A Critique of Bruce Ackerman's Theory of Constitutional Moments, 44 STAN. L. Rev. 759 (1992); Walter Burnham, Constitutional Moments and Punctuated Equilibria: A Political Scientist Confronts Bruce Ackerman's 'We the People', 108 YAlE L. J. 2237 (1999); Sujit Choudhry, Ackerman's Higher Lawmaking in Comparative Constitutional Perspective: Constitutional Moments as Constitutional Failures? 6 INT'L J. Const. L. 193 (2008); Daniel Young, How Do You Measure a Constitutional Moment? Using Algorithmic Topic Modeling To Evaluate Bruce Ackerman's Theory of Constitutional Change, 122 YALE L. J. 1990 (2013).

75 See generally MoHSEn Milani, The MaKing of IRAN's Islamic REVOlution: From Monarchy TO ISLAMIC REPUBLIC (1994). 
Applying this grand view on comparative constitutionalism we can spot four critical time points in constitutionalizing popular movements. ${ }^{76}$ At the first time point, the leader of the movement challenges the legitimacy of the current political order. At the second time point, the charisma of the leader of the movement leads to a constitution as a legitimizing document. During this time, the charisma of the leader becomes constitutionalized. In other words, as the charisma of the leader dwindles the constitutional authority of the legal establishment rises. At the third time point, a succession crisis occurs after the charismatic leader passes away, resigns, or simply quits politics. The succession period results in the bureaucratization of charisma. This might lead to the downgrading or weakening of constitutionalism. At this time, normal politics take over the constitutional moments by creating a top-down political party system. This creates tension with the judicial body as it observes constitutional elements being undermined. At the fourth time point, the judicial body purports to safeguard the constitutionalism in a battle with other forces and branches of government. The cycle of constitutionalism ends with the judicial body protecting the constitution.

This discussion discusses the constitutionalism of the Iranian Revolution in three phases: 1. The formulation phase explores the events leading up to the Revolution and its immediate aftermath. In this chapter, the dissertation shows how the idea of the Iranian Constitution was morphed. It focuses on the ideas of Khomeini, the leader of the Revolution, and the viewpoints of the drafters of the Constitution. 2. The establishment phase assesses how the ideas of the leader and the revolutionaries became embodied in 
the Constitution of the Islamic Republic of Iran. It endeavors to comprehend the transformation of the ideas of revolutionaries into the Constitution as well as the suppression of alternative narratives. 3 . The succession phase deals with the death of the leader and its aftermath. This chapter analyzes how the charisma of the leader was bureaucratized and impacted the amendments of 1989 of the Constitution. This chapter aims to assess the impact of the end of charisma on the rule of law, the constitution and the political legal culture of Iran in the following years.

This research applies this four-stage methodology in studying the history of Iranian constitutionalism. It looks at critical ruptures and historical junctures that left important marks on constitutionalism in Iran and had an impact on its international behavior. This research also applies a version of the liberalist framework to understand the extent to which constitutional politics had an impact on the international commitments of Iran.

\section{Sparking the Flame: Revolution}

\section{A. Revolt against Despotism}

The Iranian Revolution came as a shock to many, including the US Government, which lost an important ally in the region. The popular revolt against the Shah's regime marked 
the first and probably the largest uprising in the Middle East in the modern era. A year before the massive movement of people, the idea of a revolution in Iran was unthinkable. ${ }^{77}$ The underlying cause(s) of the Iranian Revolution ha(ve) remained highly contested. Several theories have attempted to explain the Iranian Revolution. Similar to recent analyses of the Arab Spring, an economic explanation serves as one of the main theories examining the Iranian Revolution. Simply put, this theory points to ill-chosen economic strategies as well as excessive governmental expenditure, income inequality and related factors as main causes of the Iranian people's revolt. ${ }^{78}$ Yet, the economic explanation can hardly describe the widespread dissatisfaction prior to the Revolution. ${ }^{79}$ The Iranian economy enjoyed unprecedented growth during the Shah's period due to many factors including an unexpected surge of oil prices and massive investment in infrastructure. In fact, Iran's growth-roughly $9.6 \%$ from 1960-1977, according to the World Bank-exceeded the average of other countries in the World. ${ }^{80}$ It is fair to say, however, that the economic growth led to the strengthening of the middle class, which in turn found the chance to strongly demand its pursuit of liberty and justice. ${ }^{81}$

77 Charles Kurzman: The Unthinkable REVOlution IN IRAN 1 (2004).

78 JAHANGIR AMUZEGaR, THE DYNAMiCS OF THE IRANIAN REVOLUTION: THE PAHLAVIS'S TRIUMPH AND TRAGEDY 53-54 (1991).

79 A very common explanation points to the lavish spending of the Shah's government especially after the oil price skyrocketed. Shah and his wife's dream of making Iran a Western-like country in the Middle East inspired them to spend excessive money on ceremonies and luxurious events which, it is widely believed, infuriated the middle class people, VALI NASR, FORCES OF FORTUNE: The Rise of THE NeW Muslim Middle Class AND WHAT IT WILl MEAN FOR OUR World 132135 (2009).

80 JAHANGIR AMUZEGAR, IRAN’s ECONOMY UNDER THE ISLAMIC REPUBLIC 4-7 (1997).

81 For a general view on the impact of middle class in the Middle East politics, see NASR, supra note 3 at 1-28. Nasr believes that the tie between Shah and the middle class was dismantled due to the 
Other analyses pinpoint alternative factors as drivers of the Iranian Revolution. The sociological explanation magnifies the effects of modernism and the respective cultural shock in Iran. Undoubtedly, Pahlavi's regime contributed to the modernization of Iran through the building of railroads and universities to establishing a more efficient and stable bureaucracy that is required for running a modern state. Iran had never experienced such a rapid headlong rush into modernism in its history. The efforts to modernize Iran during the Qajari Dynasty were limited to military equipment and low-scale bureaucratic changes. ${ }^{82}$ It was not until Pahavil's era that an unleashed modernism transformed the lives of ordinary people in Iran especially in big cities. Unsurprisingly, it brought about backlash from the society particularly from the traditional and religious sector. The religious sector, either independently or due to the pressure it felt from its base, started to issue fatwas and orders limiting or prohibiting certain aspects of modernism. ${ }^{83}$ This coincided with the influence of leftist ideas coming from Iran's neighbor, the Soviet Union. Gradually, a wide range of domestic leftist literature was produced by a group of scholars and journalists as well as religious people. Soon, a few Western educated scholars, most notably Shairati, came up with a combination of the Islamic and Marxist

coup that overthrew the democratic government of Mosadegh, Id. at 122-124. He believed the middle class finally found its hero in Khomeini, $I d$. at 129.

82 During Qajari's Dynasty, Iranians exposed to West and its new industrialized face, mainly through military encounter. At the time, the Iranian military was very weak and disorganized. The rulers did not pay attention to modernize the military with training and new equipment. Only Abbas Mirza, the Crown Prince, made several attempts to modernize the military. He died in 1833 after series of defeats Iranians had from Russians. Iran lost large portions of lands following each defeat to Russia, NikKIE R. KedDie, Modern IRAN: RoOts and RESUlts of REVOlution $27-30$ (2003).

83 In one of the notable examples, the religious people with the leadership of some clerics denounced the introduction of showering. At the time people would bath in a small pool the measurement of which was dictated by religious clerics. With the use of force, Reza Shah broke the resistance of people and eventually water pipelines and showers became widespread. 
narrative, which was widely embraced and read. Khomeini's anti-modernism rhetoric could aptly garner support from the disgruntled group of people shocked by the effects of unexpected modernism. ${ }^{84}$

Not surprisingly, the literature is replete with narratives that enumerate the demand for Islamization as the underlying cause of the revolution. The Islamic Republic of Iran's government has propounded this narrative for the last three decades through its official and unofficial media channels. Ironically, however, several analyses in the West have also followed this narrative by depicting the Iranian Revolution as purely Islamic and framing it under a common buzzword, fundamentalist. ${ }^{85} 86$

Yet, framing the Iranian Revolution under the paradigm of Islamization as well as fundamentalism does not correctly explain the nuances of the Revolution and its aftermath. First and foremost, Shiism, as the leading religion in Iran, has not historically offered a theory of government. In fact, Shia jurists staunchly shunned taking political positions, as they believed that domain belonged to monarchs and rulers. Khomeini's ideas of the leadership of an Islamic jurist became widely known much later in the

84 AMUZEGAR, supra note 2, at 39.

85 See e.g. Michael Richards, REVOlution In WORld History 73 (2004); P.J. TiERney, THEOCRACY: CAN DEMOCRACY Survive Fundamentalism? Resolving The Conflict BETWEEN FUNDAMENTALISM AND PLURALISM 106 (2012) [arguing that that the religious hardliners successfully used the general frustrations resulted from modernism in Iran to advance their theocratic and fundamentalist ideas.] BEVERLEY MiLTON-EDWARds, IsLAMIC FUNDAMENTALISM SINCE 1945 81-83 (2005) [arguing that the Revolution was a result of Khomeini's fundamentalist ideas in addition the Iranian left.]

86 The word fundamentalism carries a negative connotation. It is a difficult term to define but it is yet commonly used to describe various movements, organizations, and states. To roughly delineate the concept, it refers to ideas that reactive in character, dichotomous in nature (seeing the world in black and white, good and evil), messianic in its historical approach, LEONARD WEINBERG \&

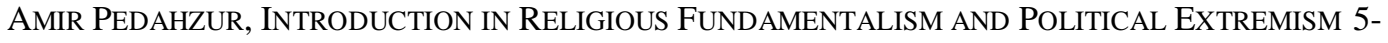
6 (Leonard Weinberg \& Amir Pedahzur eds, 2004). 
Iranian movement, a fact indicating that people did not revolt, questing for Islamization. Moreover, the text of the Constitution, speeches of Khomeini before and after the revolution as well as the struggle of the Iranian Government in the implementation of Islamic rules in the past thirty years serve as other indicators that we should not make the mistake of equating the Iranian movement with an Islamic or fundamental movement. ${ }^{87}$ Furthermore, as noted by scholars, contrary to the commonly held belief, the Iranian Revolution did not stand as a model or prototype for fundamentalist movements in the region, many of which existed long before the Iranian Revolution. ${ }^{88}$

The demand of rule of law as a crucial cause for the Revolution of Iranians has remained an often-neglected narrative. The intellectual debates surrounding the Iranian Revolution have been hijacked either by economic-centric liberals or religion-oriented conservatives, both of whom ignore the demand for rule of law and the role it played in the Iranian Revolution. The Iranian Revolution should be seen in light of the Constitutional Movement of 1905 and Mosaddegh's Movement of 1951 as well as the Reformist Movement of 1997 and the post-2009 election protests. The common thread that links all these movements does not revolve around economic prosperity demands or a quest for the governance of Islamic values; in all of the movements a strong and predominant

87 The Islamization paradigm rests on the presupposition that it is the culture, which drives the politics as well as social movements. However, some scholars believe that at the time of political development every other aspects of a society including cultural demands become subjugated to politics, Behrooz Moazami, State, Religion, and Revolution in Iran, 1796 to the Present 117-119 (2013).

88 STEPHEN W. WALt, REVOlution AND WAR 247 (1996) [“...most contemporary Islamic movements predate the revolution in Iran, and their growing popularity is due more to indigenous trneds than to the transmission of revolutionary ideas from Tehran."]; Walt keenly observes that as much as the Iranian Revolution could have inspired other movements, it equally warned against the dangers and turmoil following such massive mobilization, Id. at 248. 
demand for democratization and the rule of law can evidently be observed. The rule of law narrative allows us to have a better grasp of the Iranian Constitution as well as the aftermath of political developments in Iran.

\section{B. Structure of the Revolution}

Understanding the structure and framework in which the revolution emerged and developed, is critical to comprehending the rule of law in Iran. The current literature tells us in detail the socio-economic developments of Iran during the Shah's regime and the Iranian movement. Little attention has been paid to the normative aspect of the Iranian movement; which in the following years has delineated the constitutional as well as political culture. Normative assertions do not merely serve as a cover for underlying socio-economic demands. The movements are shaped, transformed or defined by the normative claims of the leaders and followers of the movements. First, we take a brief look at the socio-economic transformation of Iran during the Shah's time that significantly contributed to the uprising of the Iranian people.

The, so-called "minor industrial revolution" 89 of Iran has caused vast changes in the society. Iran underwent a transformation from being an agrarian society to a developing industrial nation. This phenomenon along with the surge in the number of educated people created new classes in the society, which in the long run became the force of the revolution. With the unraveling of feudalism in Iran, farmers became landowners and independent. The idea of land reform came from Hassan Arsanjani, the agriculture

89 Abrahamian believes that Iran experienced a minor industrial revolution between 1963-1977 in which the share of manufacturing rose from 11 to 17 percent in the GNP of Iran, ERVAND 
minister of Iran. ${ }^{90}$ This law intended to break large pieces of land into smaller pieces and hand the ownership to farmers. The landowners or "feudalists" at the time were allowed to retain one of their villages but their other owned villages were sold to peasants working in the farmlands. ${ }^{91}$ Such a large-scale reform was not without criticism and flaws ${ }^{92}$ however, eventually it led to the creation of a new class of people with new demands. ${ }^{93}$ Overall, similar to other industrial revolutions, in Iran, industrialization resulted in the emergence of two classes of people: the new urban city middle class enjoying high levels of education; the other, the marginalized urban dwellers living in slums on the outskirts of cities, some of whom came to cities in search of a job as a result of the downfall of agriculture in Iran. The latter group's area of residence was and is, less commonly so, referred to as "steel towns" indicating the poor quality of their houses.

Another important class that played a role in the revolution was the business owners or more accurately, those who were working in the "bazar". This was not a new class. Traditionally they played a major role in the Iranian social and political movements including the Constitutional Revolution. However, the flow of unprecedented petrodollar revenue fortified this class in an unprecedented way. The facilitation of import and export along with the increasing purchasing power of Iranians - due to the high growth of

90 Arsajani was forced to resign in 1963, two years after the reform was legislated in 1962. His idea was later adopted by the Shah in the so-called "white revolution" which will be discussed later. The Shah could not tolerate Arsanjani to enjoy the popularity it gained from the land reform initiative, KEDDIE, supra note 82, at 152.

91 KEDDIE, supra note 82, at 148 (2003).

92 The main problem with the reform was that the lands allotted to the peasants were not enough and the peasants were not enough and the peasants did not have the means to maintain the lands and make them profitable, $I d$. at 152 .

93 The lot given to the new farmers was allegedly not enough for them to establish an independent and rather profitable business. 
national income-made the Bazaris economically very strong. Interestingly enough, Bazaris have been traditionally quite dependent on the clerics for legitimizing their business. In a country where positive law was not very strong yet, it was the clerics who would decide the rights and wrongs of businesses. The new Westward gestures of the Shah along with his apathetic moves towards religion increasingly lost him the support of the clerics and religious people. The disgruntled clerics garnered the support of the Bazaris. Business people traditionally would financially support the clerics under the rubric of what could be called "religious taxes". ${ }^{94}$ This made the clerics quite powerful. ${ }^{95}$

Unlike many other clerics at the time, Khomeini criticized politics with a political ideal in mind. He, similar to other clerics, remained suppressed and largely silent during Reza Shah's period. Reza Shah would not tolerate any dissidents or critiques of his policies. ${ }^{96}$ At the time also, the general conviction among the clerics rested on the idea that clerics should not interfere with politics. This conviction is deeply rooted in Shiism that historically was marginalized from mainstream politics. ${ }^{97} 98$ Mohammad Hassan

94 Khoms is the main religious tax, which equals the fifth of a Shia Muslims income per year. Khoms should be given to a high rank Islamic jurist per annual religious fiscal year

95 One of the important venues in which new theories of Shiism developed was in Hosseiniye Ershad. Several influential thinkers depicted a new image of Islam, Shiism that contributed greatly to normative aspect of the Iranian Revolution. Among those figures were Shariati and Ayatollah Mottahari. The financial support would come from Bazaris, MiLANI, at 378.

96 “...Reza Shah certainly did not countenance opposition or criticism from the clerics. There are many anecdotes about his brutal treatment of those he regarded as troublemakers. The most famous is undoubtedly the story that he stormed into the great mosque in Qom in 1928, muddy boots and all, to horsewhip a cleric who had complained about the queen visiting the shrine without wearing a veil”, Elton L. DANIEL, THE HistORY OF IRAN, 140 (2012).

97 Khomeini's theory of government is indebted to the Sunni various theories of government. Quite evidently Khomeini could not find precedent in Shiism to support his idea of ruling of a jurist, Said Amir Arjomand, Ideological Revolution in Shiism in AUTHORITY AND POLITICAL CULTURE IN SHIISM (Said Amir Arjomand, ed. 1988). 
Boroujerdi, who had tremendous influence on the Qom seminary, believed firmly that the clerics should stay away from politics. Boroujerdi's intellectual dominance over the Qom seminary would not allow Khomeini to voice his political opinions publicly. ${ }^{99}$ Following the death of Boroujerdi in 1961, the Qom seminary became more pluralized. ${ }^{100}$ Khomeini seized the first opportunity and established himself as one of the leading Islamic jurists who eventually attracted many followers. ${ }^{101102}$ However, it was not until 1962 in which he publicly flexed his muscles, directly against the Shah.

During the Shah's visit to the US in 1962, it became clear that Kennedy and the US government supported reform efforts in Iran, which had already started with Amini the Prime Minister at the time. The purpose of the Shah's trip was to convince Kennedy that Iran needed more military equipment so it could curtail the threat of communism in Iran

98 Probably the first theory of government in Shiism emerged in when Safavid Dynasty ruled Iran and for the first time declared Shiism as the religion of the land. Even then, the clerics devised a theory of government which basically would recognize the Safavid monarchy as a legitimate government until the last Imam of Shia would re-emerge, VALI NASR, THE SHIA REVIVAL, How CONFLICTS WITHIN ISLAM WILL SHAPE THE FUTURE 74-75 (2006)

99 In the event of Mossadegh movement, Boroujerdi in fact sided with the Shah. Mossadegh who became the leader of democratic movement in Iran and hero of nationalization of oil in Iran, had a clash with the Shah. At the time, other clerics including Ayatollah Kashani and Ayatollah Shariatmadari decided to support Mossadegh publicly, ABBAS MiANI, EMINENT PERSIANS 369-370 (2008).

100 MiLANI, Id. at 371.

101 "Khomeini's rise to prominence began with the death of Ayatollah Boroujerdi on March 30, 1961”, Milani, Id. at 353.

102 Amini, the then prime minister, took a trip to Qom to visit the top clerics at the time. Khomeini was amongst clerics that Amini visited. Milani suggests that reason for inclusion of Khomeini in that list is still unknown today because Khomeini at the time was not considered a top echelon cleric. Interestingly enough, in the meeting with Amin, it was Khomeini who did most of the talking and more importantly talked on behalf the "people", ABBAS MiLANI, THE SHAH 273 (20112012). 
and stand as a wall against the expansion of the Soviet Union. ${ }^{103}$ Upon his return to Iran, the Shah seemed determined to implement certain social reforms, which later were called "the White Revolution" or "The Shah and People Revolution." ${ }^{104}$ With the help of the newly appointed prime minister, who is commonly regarded as a mouthpiece of the Royal Court, the Shah embarked on starting reforms. The White Revolution entailed 19 reforms, six of which were introduced in $1962 .{ }^{105}$ Although the reforms seemed to be essential, the mistrust between the Shah and the clergy class caused a backlash with Khomeini establishing himself as the main critic and opponent. One of the reforms included a change in the local election law, a matter that seemed insignificant at the onset. The new law mandated that oath be taken with a book, eliminating Quran as the only source for taking oath in consideration of other religious minorities in Iran.

103 The Shah and Kennedy's view did not converge on this point: "the Shah was worried about the Soviet Union and Iraqi threat and wanted a bigger army and more military expenditures, while Kennedy believed the biggest threat facing the Shah was the domestic situation and wanted to push for more reforms and a bigger slice of the budget for social expenditures. Since it was the U.S. Government that had to pay for much of any expansion of the Iranian military, Kennedy's views carried particular weight." MILANI, supra note, at 285.

104 The White Revolution allegedly originates from a news paper article that stated that the reform was necessary and it could be implemented within one of the two paradigms: red revolution of the Soviet Union and the White Coup of the United States. The term White Revolution was first used by Amini, MILANI, supra note, at 290.

10519 elements of the White Revolution are: 1. Land reforms program with the aim of abolishing feudalism in Iran by buying lands from land ords and selling it to the peasants below the market value with some other financial incentives. 2. Nationalization of forests and pasturelands. 3 . Privatization of the government-owned enterprises. 4. Profit sharing for industrial workers by allowing them to have $20 \%$ share of the net profits of the industry in which they worked. 5 . Suffrage for women. 6. Formation of the literacy corps by sending educated people to rural areas in order to eradicate or minimize the then high illiteracy rate. 7. Formation of the health corps. 8. Formation of reconstruction and development corps. 9. Formation of houses of equity 10. Nationalization of all water resources 11. Urban and rural modernization and reconstruction 12. Education reform 13. Expanding worker's right to own shares in the industrial complexes 14. Price stabilization 15. Free and compulsory education 16. Food stamps for mothers in need of financial help 17. Introduction of social security and national insurance 18. Stable and reasonable cost of renting or buying residential properties 19. Introduction of measures to fight against corruption, Iran: The White Revolution, Time Magazine, Feb 11, 1966. 
However, this matter infuriated Khomeini who, in an unprecedented move, sent two letters with a messianic tone directly addressing the Shah in which he openly criticized the new practice of oath taking and warned against its consequences. Khomeini in his letters did not just voice his opinion but framed it as national interest and people's demands:

"...Islam is not indicated as a precondition for standing for office and women are being granted the right to vote... as you know, national interests and spiritual comfort are both predicated on following Islamic laws. Please order all laws inimical to the sacred and official faith of the country to be eliminated from government policies." 106

Surprisingly, the Shah responded, telling Khomeini that "new laws proposed by the government contain nothing new, and I want to remind you that I more than anyone am keen on respecting our religious roles." 107 The Shah did now show signs of withdrawal from the policy in the letter, however, he responded to Khomeini, a fact that helped Khomeini in the process of establishing himself as a representative of Muslims and Iranians. Khomeini did not stop there. He responded to the Shah's letter cautioning him to avoid the "wrath of Muslims". Neither side showed any compromise in their stance. However, eventually the clergy won the battle when Alam, the prime minister, declared that the proposed election bill was withdrawn. Not long after that, the Shah announced his "Shah and People Revolution" program.

106 MiLANI, supra note, at 291 [Translate the letter yourself]

107 Id. [Translate the letter yourself]. The Shah tried to humiliate Khomeini by calling him "Hoja tol eslam" instead of "ayatollah". Hojat to eslam is a lower rank classification of clergies indicating, inter alia, that they do not have and cannot have official followers. 
The clergy became disgruntled about two elements of the so-called White Revolution: the right of vote for women and the land reform. ${ }^{108}$ The Shah knowingly started a fight with clerics over these reforms, delivering lectures dubbing the clergy as "black reaction" which have "little, empty and antique" brains. ${ }^{109}$ The Shah held a referendum in which women could vote, to show that the majority of people supported the so-called White Revolution. 99.5 percent of voters agreed with the reform in a highly questionable referendum. ${ }^{110}$ Khomeini, however, took a rather different route than other clerics. Instead of focusing on women's suffrage and the land reform, he targeted the bigger picture. He framed the reforms as mandates of Americans and Israelis and he ordered Muslims to boycott the referendum. He declared that the reforms would pave the way for further influence of the West, specifically the US, into the affairs of Iranians. His narrative was centered on anti-colonialism. ${ }^{111}$ The heated rhetoric of Khomeini with the relentless support for the reforms by the Shah resulted in the establishment of the Khomeini-Shah dichotomy; which eventually materialized in the form a street clash on June 5 of 1963.

108 Land reform was the idea of Arsanjani, the agricultural minister of the Amini Administration. The Shah decided to implement the project hoping to gain support from peasants and farmers. The reform was mismanaged and poorly implemented, leaving peasants with not enough land to be able to remain independent and profitable. In turn, with the rise of oil revenue, this class decided to migrate to cities. Milani believes that the unhappy peasants not only did not become the supporters of the Shah, but they served as foot soldiers for the Islamic Revolution, Id. at 292-293.

$109 \quad I d$. at 295.

110 For instance, the ballot boxes were open under the surveillance of police and security forces. Id. at 294.

111 The Shah was convinced that Khomeini had accepted money and support from Nasser of Egypt. This was among the accusations when Khomeini was arrested, Id. at 301. 
Khomeini did not limit himself to lectures and heated speeches. He instituted a relationship with three underground groups in the March of 1963. The head of these three groups met with Khomeini in order to form a coalition. The meeting turned out to be successful as these leaders embarked on creating a national network in order to organize demonstrations, protests, distribution of materials etc. Later on, Khomeini's declarations were distributed via the help of this network among other venues. ${ }^{112}$ Furthermore, the group initiated a militia branch for the battles with the Shah as well as assassination attempts.

The clash of June 5, 1963 reified what could be aptly called the "Khomeini Movement." 113 It was followed by the arrest of Khomeini who delivered a critical speech against the Shah on the day of Ashura, a holy day in Iran that represents revolt against a cruel ruler. Khomeini was transported to Tehran and the rumor soon spread that he might be executed. This frightening news made other senior clergies submit a proclamation stating that Khomeini is in fact a marja taghlid, i.e. the highest stature in Shiism, which literally means the source of emulation. This initiative would have prevented the execution of Khomeini had the government intended to so because due to an unwritten constitutional rule an Islamic jurist of that high rank could not be executed. The initiative proved to be successful and Khomeini was released.

112 "It was a measure of the power of the new group in 1963 that they could distribute 250,000 copies of some of Khomeini's proclamations.” Id. at 296.

$113 I d$. at 303 (for forces loyal to Ayatollah Khomeini, June 5, 1963, was nothing short of the birth of the "Khomeini Movement.") 
Khomeini's exile from Iran marked a critical moment in the path of the Iranian movement. Following the release of Khomeini from imprisonment, he continued to voice his objection to the Shah's policies. In October 6, 1964 the Parliament of Iran passed a law at the proposal of the Prime Minister Hassan-Ali Mansur, which was commonly referred to as "Capitulations". The law was actually a Status of Forces Agreement (SOFA) with the United States because the Shah insisted on the US army training Iranian military. This law bestowed immunity on the US armed forces in the event of wrongdoings and delegated trial to the American military courts. This law infuriated Khomeini as the most vociferous opponent of the bill who quickly reacted by delivering an acerbic and critical speech. He emphasized the national humiliation resulting from the law, by which no one could protest if "an American cook runs over the Shah, or a marja, or a high-ranked official." Later, he issued a statement focusing on the Islamic rule that mandates that infidels have no control over Muslims. At this time, the Shah decided to exile Khomeini. ${ }^{114}$

By the time Khomeini was exiled, he had already established himself as the foremost opponent of the Shah and the leader of the opposition movement. Furthermore, he had achieved the highest stature in Islam, and was accepted as one of the Maraj taghlids in Iran. He was also astute enough to establish a network of underground supporters so that his messages could traverse across the various groups of people. Contrary to what the Shah had in mind, exile did not erase Khomeini from the memory of the people.

114 "The Prime Minister soon paid with his life for his role in the affair, and Khomeini was catapulted into the center of Iranian politics." Id. at 307. "The events of 1963 had clearly affected the Shah's physical and psychological condition. In February 1964, accompanied by the Queen, he took a trip to Europe." Id. at 307. 
Conversely, exile idolized Khomeini whose statements were widely distributed and read with passion. Exile did not throttle the movement of the revolution yet expedited it. Living in exile also provided time for Khomeini to formulate the structure and nuances of the future government.

From then on, the Shah's government started to stumble between two extremes: military authoritarianism and a reformist government. ${ }^{115}$ This oscillation proved the inability of the Shah and his aides to handle the crisis and revealed the weaknesses of the Shah to the opposition. Khomeini, on the other hand, gradually gathered a group of highly educated and democratic individuals who helped him create the liberal rhetoric needed to win the support of the middle class and even secularists in Iran. The strong endorsement of influential thinkers and skilled orators such as Shariati also tremendously helped Khomeini in garnering the trust of the middle class of Iran. ${ }^{116}$

Ironically, Khomeini united incongruent paradigms at play before the Revolution to target the Shah's regime's legitimacy. There were at least four paradigms of resistance prior to the Revolution:

"Secular nationalists wanted democracy, rule of law, and empowered civil society, and a market economy; religious advocates of modernization wanted a modicum of democracy, within a reformed Shiism that would provide the society's moral fiber along with a

115 Id. at 387. ("The Shah swung from one extreme to another, invariably to disastrous result. Khomeini, dangling a tactical but tantalizing democratic platform, used each of the Shah's moves to him own profit, ultimately convincing Sullivan that he would create a democratic polity in Iran.”)

$116 I d$. at 378. ("By the early seventies Khomeini had found supporters amongst secular intellectuals as well...more than any other ideology, the writings of the likes of Al-Ahmad and Shariati prepared the context for Khomeini's leadership of the democratic movements.") 
market economy...the third paradigm was promoted by radical Marxists, who wanted modernization forced on society by the absolute power of a state controlled by their "vanguard party," a planned economy, and a Russian tilt in Iran's foreign policy...A separate paradigm, critical of modernization and modernity and rejecting the desirability of both, came notably in the ideas of Ayatollah Khomeini."'117

Khomeini became the leader of the Iranian movement, uniting proponents of each paradigm who became convinced that Khomeini would be the messiah advancing each of their causes. Khomeini's exile helped tremendously in creating an image of an idol and a messenger that would ultimately return with a miracle to transform and revolutionize political order, an order that had dominated Iran for 2500 years of monarchy. ${ }^{118}$

117 Id. at 435-436. Milani continues: "The paradox of the fall of the Shah lies in the strange reality that nearly all advocates of modernity formed an alliance against the Shah and chose as their leader the biggest foe of modernity", Id.

118 The Shah liked to emphasize that he was a successor of 2500 years of monarchy in Iran. Eventually in a flamboyant yet highly controversial ceremony in 1971 he celebrated the 2500 years of monarchy in Iran. The excessive amount of money squandered in the ceremony is widely believed to have had an everlasting impact on the society, which grew resentment towards the Shah and his court's unnecessary extravagance, Id. at 322-323. 


\section{Legalizing the Revolution: Drafting}

\section{A. Battle of Drafts \\ 1.Paris Draft}

The draft of the constitution has undergone a long intellectual journey from the Paris version to the version published for comments. One can see the gradual Islamicization process as the Islamic forces became more powerful. The first versions did not contain "subject to Islamic laws" in many clauses. Later on however, not only was this phrase added to many of the Articles of the Constitution but also the Principle of Guardianship of a Jurist became the most important Article of the Constitution.

The idea of writing a constitution for the Iranian Revolution arose when Khomeini was in Paris. He called up one of his aides, Dr. Hassan Habibi, to prepare a draft of the 
constitution. Dr. Hassan Habibi received his $\mathrm{PhD}$ in Law and Sociology from the University of Paris 1, Panthéon-Sorbonne. Later, in February 1957 Khomeini expressly and publicly talked about drafting a new constitution for the revolution. According to Seyed Sadegh Tabatabi, brother of a daughter-in-law of Khoemini, it took a few weeks of night and day work until the first draft was prepared. Khomenini also approved the draft, which was also sent to receive feedback from a few other religious authorities. According to Ayotallah Yazdi, the draft sent to other religious authorities contained remarks and comments of Khomeini on its margins. ${ }^{119}$

The first draft of the constitution stipulated a position for a prime minister and a president. It also designed a Council (which was called the Council of Guardians) similar to the Constitutional Council of France to ensure the constitutionality of the enacted legislations. The similarities with the French Constitution stirred controversies among conservatives and religious authorities that denounced the new constitution as highly inspired by Western ideas. Interestingly enough, the first draft did not contain the very controversial principle of Velayate Faghigh (Guardianship of a Jurist). This principlelater added to the Constitution — states that an elected Islamic jurist should govern and guide the main affairs of the republic. We will talk about this principle later in depth.

\section{Tehran Draft}

Parallel to the constitutional drafting endeavor that started in Paris, in Iran a group of lawyers and scholars started to prepare a draft. This group was more inclined to the Azadi

119 http://www.feirahi.ir/?article $=158$ 
party (liberal party) and in addition to the French Constitution, was influenced by the constitutions of Soviet Union, Algeria as well as by the Universal Human Rights Declaration. There were 6 people who started to seriously engage in drafting the constitution: Dr. Hassan Habibi (who previously came up with his own draft in Paris), Dr. Mohammad Langaroodi, Dr. Lahiji, Dr. Minachi, Banisadr and Dr. Katooziyan. This draft also was seen by Khomeini and was approved by him. This draft was published by a widely published newspaper at the time (Keyhan) and was later submitted to the Assembly, which was responsible for finalizing the text of the Constitution. This draft had seven sections: 1) General Principles and Objectives (11 Articles) 2) Ownership (11 Articles) 3) People's Rights (35 Articles) 4) Legislative Branch (31 Articles) 5) Executive Branch (46 Articles) 6) Judiciary Branch (15 Articles) 7) Guardians of the Constitution (10 Articles). ${ }^{120}$ It is worth mentioning that the current Constitution of Iran has a structure very similar to this draft.

The latter draft of the constitution is derived from three main paradigms: Western republicanism, reformist approaches to Islam, and anti-colonialist ideology. The two pillars notable in various principles were the governance of people and protecting the boundaries of Islam. In other words, people should govern themselves through democracy but within the ambit of what's permissible in Islam.

\section{Transition Government Draft}

120 http://www.feirahi.ir/?article $=158$ 
Following the Revolution, the idea of constitutional writing was one of the priorities of Khomeini. In his appointment letter of the head of the transition government, he set out the details of a special assembly for constitutional drafting. Following the Revolution, a council was established in order to plan and regulate the transition from the old system to the new government. One of its mandates was to establish an assembly for constitutional drafting. The Assembly was eventually constituted and reviewed the Paris and Tehran Drafts along with other countries' constitutions, which it received from various consulates in Tehran. The Assembly mainly took into account the Paris draft yet with a major revision. Ezatolah Sahabi, a member of the Assembly explains this revision thusly:

"In the Transition Government, a Council was established which bore the title 'Council of Revolutionary Proposals' over which my dad presided. Under his supervision we held a few sessions regarding this Constitution....Mr. Habibi's draft [Paris Draft] was proposed. They made a few changes to it. The major change that I remember was that they reduced the authorities of the President and expanded the authorities of the Prime Minister. They believed that Mr. Habibi's draft was influenced by the French Constitution of the fifth republic, which De Gaulle had it ratified in 1985. The power of the President was very expansive whereas the Prime Minister's authority has been decreased. The president was not in charge of the parliament. The president was elected directly by the people whereas the prime minister, who was elected by the parliament, was in charge of the people. Otherwise, they did not modify the draft until the draft was introduced to the Council of the Revolution." 
The Transition Government Draft differed from the Paris and Tehran Drafts in that it was mainly influenced by the presidential system and the drafters were inspired by the 1905 Constitution of Iran among other sources.

\section{Revolutionary Council Draft}

Later the Transition Government Draft was submitted to the Revolutionary Council for consideration. A major shift happened in the approach to constitutional writing in the Revolutionary Council. A leftist approach was infused into the prepared draft of the Transition Government, which was thought to be too liberal. For example in the Transition Government Draft, ownership was linked to labor (Lockean notion), which faced resistance in the Revolutionary Council.

Another important revision was adding "pursuant to Islamic guidelines" almost at the end of each article of constitution. At this stage, the Constitution underwent an Islamicization process. This draft was later sent to Khomeini for his approval.

Khomeini commented on 6 articles of the draft, however, he eventually accepted the draft version in three points but not in the rest. The three points he raised was on 1) the requirement of being Shiite and male for nomination to presidency (in the draft it only mentioned "Muslim Iranian" as a requirement) 2) the design and format of the national flag 3) minority rights in regions of Iran where they hold majority. Interestingly enough, Khomeini did not raise any issue regarding the Guardianship of a Jurist Principle (Velayat Faghigh) in his comments. 
Subsequently, the draft was published in a newspaper. Khomeini called for opinions and comments on the draft. In a subsequent speech this is how he framed his call for comments on the draft:

"Right now every sector and all religious authorities and Islamic intellectuals should review this law and should comment.....on the Islamic Constitution only those who know Islam should comment and not foreign intellectuals.....we all have the right to comment on this constitution and you religious jurists have more right to comment...Those who know Islam and like Islam should endeavor more and should be at the forefront."

Subsequent to this call for comments, many organizations, parties, individuals and even lay persons started to comment on the draft. Some groups even came up with their own draft of the constitution. Each group approached it from its perspective. For example, Islamic jurists were worried that the constitution did not sufficiently account for Sharia (Islamic laws). Leftist groups found it to be too liberal.

Khomeini remained silent about the specifics of the draft. However, he commented on several occasions emphasizing the interplay between Islam and republicanism. He stated:

"But the republic (aspect) has the same meaning given in other parts of the world to this term. But this republic is based on an Islamic Constitution, which is Islamic law. What we mean by Islamic Republic is that the conditions pertaining to election and its execution should be based on Islam. But, people should elect and the form of the republic is the same as it is elsewhere."

Khomeini never mentioned anything about the Guardianship of a Jurist Principle in this time. However, many of the Islamic jurists came out as opponents of the draft 
constitution because it was not sufficiently Islamic for them. Among them was Ayatollah Montazeri who suggested that the principle of Guardianship of a Jurist to be added to the constitution. He sums up his position as follows "the constitution should be drafted in a way that the Islamic Jurists become pivotal for the Government and play a major role in (enacting) the laws. However, in the current draft they do not have such a role". He later on became the president of the Assembly of Constitution Experts, the body responsible for finalizing the text of the Constitution. Not surprisingly, his ideas became very influential in this Assembly. Interestingly enough, several years later he was marginalized and subject to house arrest because of his opposition to the Government. ${ }^{121}$

\section{B. The Assembly of Constitutional Experts}

The Assembly of Constitutional Experts was a body responsible for discussing and finalizing the text of the constitution. The people elected its members with the total number of 75 representatives. This was the first election after the Iranian Revolution. (However, one should bear in mind that the first popular voting happened a few months after the revolution. Khomeni ordered that a general voting be held so people could

121 A brief overview of his life could be found here (in English): http://www.pbs.org/wgbh/pages/frontline/tehranbureau/2009/12/grand-ayatollah-hossein-ali$\underline{\text { montazeri-1922-2009.html }}$ 
convey their opinion about the type of government they want via ballots. In this general voting, 98\% voted yes to the "Islamic Republic of Iran". )

The Islamic groups and specifically those who had the support of Khomeini won the majority of the seats. In fact, some other groups did not even obtain one seat in the Assembly. Fifty eight elected representatives in the Assembly were Islamic jurists with different levels of Islamic education. Other groups, which experienced a drastic defeat including leftists, liberals, nationalists and seculars, objected to the result of the election. A few groups wrote letters to Khoemini laying out the various violations that happened during voting. None of the objections led to any result. The Assembly started its work and finished reviewing the draft after three months (with several nudges from Khoemini who wanted the Constitution to be delivered to people as soon as possible.)

The most controversial Article of the Iranian Constitution was the one stipulating the Guardianship of an Islamic Jurist. Practically, this principle sets out the underpinning legitimization narrative of the Iranian Constitution. The text in 1978 draft was as follows (it was later amended in 1989):

"In the time that the Shia' $12^{\text {th }}$ imam is absent, in the Islamic Republic of Iran the guardianship and leadership of the people rest on an Islamic jurist who is just, pious, aware of current affairs, courageous, a skillful manager whom the majority of people recognize and accept as their leader. In case no Islamic jurist holds such a majority, the Supreme Leader or the Council of Leaders consisting of several high standing Islamic jurists will be selected pursuant to the Article 107 of the Constitution."

The current version of the principle is as follows, subsequent to the 1989 amendment: 
"In the time that the Shia' $12^{\text {th }}$ imam is absent, in the Islamic Republic of Iran the guardianship and leadership of the people rest on an Islamic jurist who is just, pious, aware of current affairs, courageous, a skillful manager whom will be selected pursuant to the Article 107 of the Constitution." 122

As mentioned earlier, Ayatollah Montazeri was the head of the Assembly. He had an undeniable role in the inclusion of the Guardianship of a Jurist Principle in the Constitution. In an extensive research Mohsen Kadivar analyzed the intellectual journey of Ayatollah Montazeri from the Assembly until his final apology for inclusion of the Guardianship of a Jurist Principle in the Constitution. ${ }^{123}$ He believes the Constitution of the Islamic Republic provides less restriction for the Supreme Leader compared with the 1905 Constitution's limitations of kingdom. ${ }^{124}$

122 The current version of the Article 107 is as follows:

“(1) After the demise of Imam Khumayni, the task of appointing the Leader shall be vested with the experts elected by the people. The experts will review and consult among themselves concerning all the religious men possessing the qualifications specified in Articles 5 and 109. In the event they find one of them better versed in Islamic regulations or in political and social issues, or possessing general popularity or special prominence for any of the qualifications mentioned in Article 109, they shall elect him as the Leader. Otherwise, in the absence of such a superiority, they shall elect and declare one of them as the Leader. The Leader thus elected by the Assembly of Experts shall assume all the powers of the religious leader and all the responsibilities arising therefrom.

(2) The Leader is equal with the rest of the people of the country in the eyes of law."

The translation of this article is adopted from this website: http://www.servat.unibe.ch/icl/ir00000_html

Note that the version before the amendment referred to council of leaders, which was eliminated in the amendments of 1989.

123 http://kadivar.com/?p=3971

124 This student comment might be helpful to grasp the general picture of Iran constitionalism: https://www.law.upenn.edu/journals/conlaw/articles/volume1/issue2/Shevlin1U.Pa.J.Const.L.358( 1998).pdf

See

also:

http://fletcher.tufts.edu/AlNakhlah/Archives/ /media/Fletcher/Microsites/al\%20Nakhlah/archives/pdfs/hasib.ashx 
The idea of Guardianship of a Jurist comes from Khomeini and Ayatollah Broujerdi. The idea interjected in the Constitution by Ayatollah Montazeri was to frame the legitimization paradigm of the Constitution based on Islam. His ideas could be classified intro five categories according to Kadivar:

1. Guardianship of a Jurist: The purpose of inclusion of this Article in the Constitution was to provide legitimacy to the Constitution and the newly built regime via an Islamic jurist as the head of the state.

2. Ideologist: the head of the state is the leader of the Islamic ideology as well.

3. Appointment: the head of the state (Islamic jurist) is appointed by God because of its qualification. In other words, its legitimacy is derived from God and Islam and not the people.

4. Consolidation of powers: Even though there will be three distinct powers, but they all perform under the supervision of the head of the state (an Islamic jurist).

5. Mandate of Execution Guardianship of the Jurist: The head of the state should have the power to supervise implementation of Islamic rules in the society.

Another important factor in the drafting of the Iranian Constitution was the influence of communist ideas. The main inspiration was from analogy between the Supreme Leader and the main ideologue within a communist party. This is how Ayatollah Montazeri and 
Ayatollah Beheshti reasoned in the Assembly in favor of the Guardianship of a Jurist principle (Ayatollah Montzeri narrates):

"In the Assembly of (Constitutional) Experts, Ayatollah Beheshti and I argued that for example in the Soviet Union if they want to govern, because they want to implement the communist ideology, they select a person who is an ideologue and an expert on communism. We have the same argument when it comes to Islamic issues, a selected person should not only be an expert on Islamic issues but should be superior in knowledge compared to the rest of the people. He has three obligations: he should govern the Muslims' affairs based on Islamic Law; he should guide Muslims as an Islamic jurist with followers; and finally he has the adjudicative authority. Therefore, he should be the most knowledgeable person in the field and should be the most pious Islamic jurist."

During the Assembly sessions, two strands of thoughts concerning the Principle of Guardianship of a Jurist were discernible. One group including the president of the Assembly (Ayatollah Montazeri) believed that God (Shâre) has appointed the Valiye Faghih. The other group believed that people elect the Valiye Faghigh. In other words, the source of legitimacy was controversial. However, this controversy was transient, because both sides agreed that Khomeini was the person who held both popular support and the Islamic legitimacy necessary for the position.

Discussions in the Assembly of Constitutional Experts also showed an inherent tension between two principles embodied in the Constitution. One was the idea of a Guardianship of a Jurist. Another principle, however, was based on the notion that people should 
govern themselves. For instance in session 33 of the discussions, Mr. Khademi stated, "governance is only for God" 125 This was in sharp contrast with, for instance, Mr. Morad Zehi (representative of the province of Sistan and Baloochestan) who suggested that every aspect of the governance should be based on people's votes and that the Constitution should have a council-based approach with a "bottom-up" structure meaning that every council member should be appointed based on popular vote. ${ }^{126}$

The tension reached its peak in the discussions about Articles 5 and 6 of the Constitution:

Article 5: Article 5 (1979 Edition): In the Islamic Republic of Iran, during the absence (ghayba) of his holiness, the Lord of the Age, May God all mighty hasten his appearance, the sovereignty of the command [of God] and religious leadership of the community [of believers] is the responsibility of the jurisprudent who is just, pious, courageous, knowledgeable about his era, and a capable administrator, and is recognized and accepted by the majority of people as the leader. In case no jurisprudent receives such a majority, the leader or the Leadership Council, consisting of qualified jurisprudents, as mentioned above and in accordance with Article 107, assumes these responsibilities.

125 Detailed Discussion of Assembly of Constitutional Experts (Soorate Mashroo Mozakerat Majles Baressi Nahai Ghanoon Asasi Jomhori Islami), Sessions 32 to 50, pp. 944-945, available at http://www.majlesekhobregan.ir/fa/pdf/tadvin qaanoon_asaasi/qaanoon-e asaasi-2.pdf

126 Detailed Discussion of Assembly of Constitutional Experts (Soorate Mashroo Mozakerat Majles Baressi Nahai Ghanoon Asasi Jomhori Islami), Sessions 32 to 50, pp. 981-983, available at http://www.majlesekhobregan.ir/fa/pdf/tadvin_qaanoon_asaasi/qaanoon-e_asaasi-2.pdf 
Article 6: In the Islamic Republic of Iran, the country's affairs must be administered by reliance on the public vote, and through elections. These will include the election of the president, the deputies of the Islamic Consultative Assembly (Majles), the members of the councils, and other such institutions, or through a referendum in such instances as are determined in other articles of this document. ${ }^{127}$

In discussions of these proposed articles, several representatives opined in order to delineate where the line should be drawn between the Islamic aspect of the Constitution and its democratic function. Below are the main points as raised by each representative:

Mr. Moghadam Maraghei:

“'Islamic Republic' consists of two words, Islam and Republic. 'Islam' is the substance and the frame is republic. . .we are not passing law for today only. . . Imam Khomeini was exceptional. . how can we assure we have a similar leader such as him in the future?. .. Islam is eternal. . .Islam's power is in its core and laws do not give it power. . .another point is that if we change the foundation of our government which is based on popular vote to faghih's [Islamic jurist's] governance, then this will impact other articles in this Constitution and we should change them all...then we will become an institutional assembly not a constitutional assembly. .." 128

Mr. Beheshti:

127 Translations of Articles $5 \& 6$ have been adopted from World Intellectual Property Organization, available at http://www.wipo.int/edocs/lexdocs/laws/en/ir/ir001en.pdf

128 Detailed Discussion of Assembly of Constitutional Experts (Soorate Mashroo Mozakerat Majles Baressi Nahai Ghanoon Asasi Jomhori Islami), Sessions 1 to 31, pp. 373-376 available at http://www.majlesekhobregan.ir/fa/pdf/tadvin_qaanoon_asaasi/qaanoon-e asaasi-1.pdf 
"it is correct that Islam does not need any Constitution. . . but the Constitution of this society and this Revolution needs to rely on Islam. . .if our Assembly does not change or reform anything in the substance of the Constitution then we are not a constitutional assembly. . .Is Article 5 intended to negate popular vote? Is Article 5 intended to negate freedoms? Is Article 5 intended to give the governance to a certain group and a certain class? For instance, are you saying [because of Article 5] the prime minister, president, and ministers should not be clerics? Never. Show me where in this Article [Article 5] you find this meaning?. . . we emphasized in the text that 'recognized and accepted by the majority of people as leader' means that no one can impose himself as leader. . on the people. . then why is there such a principle suggested to be included in the Constitution?. . you (the people) shouted they wanted independence, freedom, and Islamic governance. . . if our future government should be Islamic republic, then the system and its leader, and its core should be put on the shoulders of those who can serve as models in all aspects, personal, political, familial, and social, in terms of their understanding of Islam and their commitment to Islam. . the idea that we give all authorities with no limits to the populace. . . is not consistent with the Constitution and our idea-based (maktabi) system because people during the Revolution and in their first referendum said Islamic Republic. .."129

Mr. Sahabi:

129 Detailed Discussion of Assembly of Constitutional Experts (Soorate Mashroo Mozakerat Majles Baressi Nahai Ghanoon Asasi Jomhori Islami), Sessions 1 to 31, pp. 376-381 available at http://www.majlesekhobregan.ir/fa/pdf/tadvin_qaanoon_asaasi/qaanoon-e_asaasi-1.pdf 
"this is a very important principle and will create a revolution in the society, do not let it pass without proper discussion. . . [after Article 5 was passed and in discussion of Article 6] Article 5 is a principle on governance and supervision of Islam or in other words Guardianship of a Jurist principle and all here accepted it. The principle of popular vote is another issue and these two principles cannot negate each other." 130

\section{Mr. Mir Morad Zehi:}

"[Unlike Mr. Beheshti] I do not think that we have a principle in Islam that every framework has been dictated by Islam. . . I believe governance has been vested by God in the people. . .I think given the fact that we passed Article 5, other principles including those reflected in Article 6 are not automatically abrogated. . the right to govern is not something that we can simply ignore and the value of popular vote is not only in electing the president. .."131

Dr. Ayat:

"the notion of national sovereignty, the notion of popular vote do not mean that popular vote can lead to whatever result. If people vote that a certain person should be a slave this vote cannot be accepted because this is tyranny based on the majority because many personal rights are inalienable meaning that a person him or herself cannot waive them let alone the majority of people. In many instances we see that popular vote is put in direct

130 Detailed Discussion of Assembly of Constitutional Experts (Soorate Mashroo Mozakerat Majles Baressi Nahai Ghanoon Asasi Jomhori Islami), Sessions 1 to 31, pp. 383, 388 available at http://www.majlesekhobregan.ir/fa/pdf/tadvin_qaanoon_asaasi/qaanoon-e asaasi-1.pdf

131 Detailed Discussion of Assembly of Constitutional Experts (Soorate Mashroo Mozakerat Majles Baressi Nahai Ghanoon Asasi Jomhori Islami), Sessions 1 to 31, pp. 403-404 available at http://www.majlesekhobregan.ir/fa/pdf/tadvin_qaanoon_asaasi/qaanoon-e_asaasi-1.pdf 
contrast with the Guardianship of a Jurist principle. Faghih is not a specific person. These are descriptions similar to where we say for example that the president should be Iranian and then you say that we violated national sovereignty [because we ascribed a feature to the presidency . . . in the principle I call velayat faghih [Guardianship of a Jurist] we said that the criteria is a vote by the majority of the people. . . therefore Article 5 that he [Mr. Mir Morad Zehi] thinks is against popular vote is in fact an emphasis on popular vote."132 Mr. Khameini:

"in this principle [as it is written - which was changed based on Mr. Khameini's suggestion] the center of the rule is 'administration of the country' which should be done based on popular vote but this administration of the country which is a general concept will be interpreted with what follows which is 'in the form of referendum - election and...' In other words, the scope of this Article will be limited i.e. opinion and supervision of the people will be only limited to these few examples and this Article [the way it is written] does not add anything new and does not establish any principle because these things existed before - but then [this Article] will limit our hands in the future and we cannot designate new ways of popular intervention and participation in the future, and therefore it is better if we add this sentence to the Article 'and other examples which will be described in other articles of the Constitution." 133

132 Detailed Discussion of Assembly of Constitutional Experts (Soorate Mashroo Mozakerat Majles Baressi Nahai Ghanoon Asasi Jomhori Islami), Sessions 1 to 31, p. 405 available at http://www.majlesekhobregan.ir/fa/pdf/tadvin_qaanoon_asaasi/qaanoon-e_asaasi-1.pdf

133 Detailed Discussion of Assembly of Constitutional Experts (Soorate Mashroo Mozakerat Majles Baressi Nahai Ghanoon Asasi Jomhori Islami), Sessions 1 to 31, p. 407 available at http://www.majlesekhobregan.ir/fa/pdf/tadvin_qaanoon_asaasi/qaanoon-e asaasi-1.pdf 
As it is shown in the discussion above, none of the proponents and opponents took the view that popular vote should categorically be rejected. Although there were considerable disagreements among the representatives, it is important to note that even proponents of Guardianship of a Jurist discussion did not view it or envision it as a replacement for popular governance. For some of them this principle was the framework to protect the 'excesses' of popular voting. For others, the fact that the leader itself would be appointed (indirectly) by popular vote signified that it was not in contradiction with the principle of popular vote.

IV. Reassurance of Revolutionaries: Establishing

Unsurprisingly, many groups contributed to the downfall of the Shah's Regime. Similar to other revolutions in history, each group had a different view of the future of the country and its constitution. Yet, it was Khomeini's narrative that eventually prevailed 
amongst competing prescriptions for the post-revolution Iran. As we discussed, Khomeini's early and tenacious resistance to the Shah as well as his exile played a critical role in creating his charisma for the revolutionaries. Yet, the question remains how Khomeini managed to create the new order and to constitutionalize his charisma, to borrow Ackerman's terminology. ${ }^{134}$ The bedrock of Iran's constitutionalism today rests on the early developments following the Revolution. Three factors contributed to the establishment of the revolution and fostered Iran's constitutionalism: 1. Building a network of supporters, 2. Establishing a supreme leader position as the ultimate arbiter of the political system and 3. Creating tension between the presidential position and the supreme leader position. These three factors developed against the backdrop of several very important historical events in Iran including the hostage crisis and the Iran-Iraq War.

\section{A. Network}

Before he left Iran, the Shah desperately decided to appoint a long dissident of his, Shapour Bakhtiar, as the prime minister in the hope that Bakhtiar's reforms would alleviate the revolutionary fervor of the populace. ${ }^{135}$ Coming from the nationalist party, Bakhtiar immediately lost the party's support when he agreed to serve as the prime minister in that tumultuous time of popular revolt. ${ }^{136}$ Upon approval of the new administration from the parliament, Khomeini quickly reacted. He ordered the

134 Bruce Ackerman, World Constitutionalism.

135 "He [Bakhtiar] ordered the release of all political prisoners and the dismantlement of SAVAK [Iran's notorious intelligence agency], began a review of all important contracts, refused oil sales to Israel and South Africa, and declared he would make major cuts in military and nuclear-plant expenditures." KEDDIE, supra note 9, at 238.

136 KEDDIE, supra note 9, at 235. 
government strikers to disrupt the governmental affairs and even prevent the new secretaries from entering their offices. Khomeini effectively paralyzed the ordinary administration of the government. However, the army was still cracking down on people in the streets. ${ }^{137}$ Bakhtiar requested to meet with Khomeini in Paris in order to find a solution to the impasse the country was facing. With victory in sight, Khomeini did not want to reconcile with Bakhtiar. He sent a message indicating that he would meet Bakhtiar only if he resigned from the Prime Minister position. Khomeini knew any meeting with Bakhtiar might convey his recognition of Bakhtiar's Government and indirectly of the Shah's reformist move. ${ }^{138}$ This meeting never happened. Nevertheless, Bakhtiar eventually allowed Khomeini to return to Iran from exile only to witness a massive marching of people welcoming him back. ${ }^{139}$

Upon his return to Iran, Khomeini made a heated speech and after a short period of stay in Tehran, he moved to Qom, implying that he did not have any desire to rule. ${ }^{140}$ In that speech, Khomeini famously stated that he would "designate a government with the support of this nation" and that he would "throw a blow at this government". ${ }^{141}$ This

137 The Shah's armed forces were not ready and equipped for internal upheaval. Iran's army was designed to project an image of regional power. This unreadiness resulted in several bloody crackdowns, which in turn infuriated demonstrators, KEDDIE, supra note 82, at 237.

138 Some people narrate that Bakhtiar intended to travel to Paris to submit his resignation to Khomeini in exchange that Khomeini appoint him as his prime minister. All the narratives however, seem to converge on the fact that it was Khomeini's entourage that influenced his decision not to meet with Bakhtiar.

139 KeDDIE, supra note 82, at 238.

140 This behavior might be related to a belief in the Shiism that Imam Ali disdained ruling and governing and shunned it until he was approached and asked by the people.

141 The word dollat in Farsi can refer to state or government. Therefore, Khomeini could have referred to that fact he would designate a new state. However, in this context, quite likely he was referring to the Bakhtiar Government, the last administration of Shah's regime. 
gesture has remained a normative power in the hands of those who believe Khomeini's goal was not to govern but leave it to the people to decide. Only a few days before his arrival, Khomeini appointed Mehdi Bazargan to the prime minister position of a transitional government. Bazargan and his government enjoyed the full support of Khomeini. ${ }^{142}$ Mehdi Bazargan received his education in France, belonged to the nationalist party, and was a practicing Muslim. He was appointed to the Provisional Government only twenty days after the departure of Shah from Iran. ${ }^{143}$ Some believe his appointment served as a conciliatory effort to reconcile between diverse groups that took part in the revolution ${ }^{144}$ while it helped to stave off potential US intervention. ${ }^{145}$ Also, Bazargan could fill the void in the managerial skills of clerks who never ruled. ${ }^{146}$

Soon, Iran had two governments: Bazargan appointed by Khomeini with the consultation of the Revolutionary Council and Bakhtiar appointed by the Shah and approved by the Parliament. Each government had a different constitutional legitimacy narrative. Bakhtiar, did not want to link his government to the falling Shah's legitimacy. He, therefore, believed that his legitimacy was coming directly from the 1905 Constitution.

142 "Opposition against his [Mehdi Bazaragan's] Government is blasphemy and punishable." Ruhollah, Khomeini, Kalam-e Imam: Nahadha-ye-Enqelabi (The Imam's Word: The Revolutionary Institutions) (Tehran, 1982), at 21.

143 Bazargan also was did not see the revolution coming. Only four months before the revolution, he was trying to convince Khomeini that the Shah's reformist move would be a good bargain and, that through a gradual plan revolutionaries could capture the executive. He also warned Khomeini about the US power and their opposition to the revolution. Khomeini disagreed. He believed Americans would not oppose the revolution and upon his return he would set up a parliament and a government himself. Bazargan was shocked at Khomeini's certitude and simple view of events, KRUZMAN, supra note, at 3.

144 BaQer Moin, Khomeini: Life of the Ayatollah 209 (1999).

145 Mohsen Rezai: "Bazargan was the biggest fraud of Imam [Khomeini] against the United States, Imam employed a person that the US would not feel threated by."

146 MiLANI, supra note 49, at 143. 
Bazargan, however, declared that it was Khomeini's decree that granted him the constitutional legitimacy. Bakhtiar's vision was to re-vitalize the 1905 Constitution, which he believed rested on the symbolic role of the King in the political system and on parliamentarism, rule of law and secularism. ${ }^{147}$ Bakhtiar's political vision was not appeasing to Khomeini who wanted to create a new political order. Khomeini struck the last blow against Bakhtiar by wresting his last winning card out of his hands, the army. Khomeini requested the army to side with the people and stop killing their brothers while calling the suppressions in the street contrary to the Sharia. On the 22nd of the month of Bahman (February 11 $\left.11^{\text {th }}, 1979\right)$, the army decided to remain 'neutral' between governments and retreated to its barracks. Three generals of the army submitted their resignation to Khomeini. ${ }^{148}$ In the afternoon of that date, people heard this from the radio "this is Tehran, you hear the true voice of the Iranian people, the voice of revolution..."149

While the Provisional Government was taking care of the day-to-day management of the country, Khomeini expanded and fortified his network. He created a network of Friday prayer preachers in mosques throughout the country and appointed the head of the television and radio organization. ${ }^{150}$ Khomeini fostered a cultural network that guaranteed that his ideas were channeled to the people in addition to the traditional

147 He saw Khomeini as a religious leader with the ambition of creating a theocracy. He believed the "Khomeini Islamic Republic" was an absolute unknown and ambiguous phenomenon.

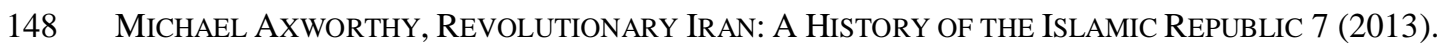

149 Who said "this is the voice of the Revolution of the Iranian people, IMAM-KHOMEINI.IR at http://www.imam-

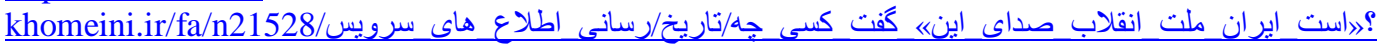

150 MiLANI, supra note 49 at 146. 
sermon channel delivered at mosques. This way, he could supervise and control the administration of affairs by the Provisional Government. Khomeini was wary of the economy too. He instituted several organizations in order to assist low-income families, to reconstruct the damaged parts of the cities, to run properties left by the Shah regime and to develop infrastructure in rural areas of the country. ${ }^{151}$ Khomeini also created a militia to act as his armed forces. In May 1979, he issued a decree establishing a special force, known as the Revolutionary Guard, to protect the revolution and to report to the Revolutionary Council. ${ }^{152}$ Due to its appeal to the revolutionary, the Guard quickly grew from 6,000 men at the beginning 1979 to 30,000 men by the end of that year. ${ }^{153} 154$

An important step in safeguarding the revolution happened a few weeks previous to this time in Paris. Khomeini-in the name of the people's support for him and pursuant to the religious right - ordered that that a council, called the Council of the Islamic Revolution, be established. The Council consisted of a disproportionate number of Islamists with no representative from the leftist camp. The original mandate for the Council pivoted around conducting preparatory work for establishing a transitional government. However, later

151 Two famous organizations were established: "the new Foundation for the Dispossessed (Bonyad-e Mosta'zafin) received the fortunes of the Pahlavi Foundation and other confiscated properties, including hundreds of companies, factories, housing units, agricultural lands, and substantial holdings in the West. The Khomeinists used this massive economic unit to recruit popular class workers and loyal managers. The Jehad-e Sazandegii (Reconstruction Jihad) mobilized youth by sending them to rural areas to aid the poor with cheap or free housing and sanctioned some seizures of urban homes and rural lands by the poor." KEDDIE, supra note 82 at 246.

152 Steven O’Hem, Iran's Revolutionary Guard: The Threat That Grows While America SLEEPS 20-21 (2012).

$153 I d$. at 24. By the end of Iran-Iraq war the Guard had 35,000 men, proportionate to the number of soldiers in the army, $I d$.

154 Mohsen Milani believes that two factors contributed significantly to establish Khomeini as the most powerful person in the post-revolution phase: "(1) the undivided commitment of a large group of zealots prepared to a defend Khomeini with their blood and (2) his prowess to lead a powerful Shi'i populist movement that swept across the country.", MILANI, supra note 49, at 146. 
the Council increasingly gained power. As the events were unfolding, the Council assumed more tasks, and, therefore, acquired more discretion in the post-revolution affairs: It became the legislative branch of the revolution before the first parliament was established. It developed "committees" under its control to combat anti-revolutionary forces. It conducted the referendum on the new format of the new government, commonly refereed to as the Islamic Republic Referendum. It reviewed and revised the constitutional draft. And finally, upon resignation of Bazargan, assumed administrative responsibilities until the election for the first president. The Council had a vital role as the backbone and 'think thank' organization during the transition period. A group of likeminded members of the Council with views similar to Khomeini's steered events towards a form of government that converged with Khomeini's ideals.

Only two weeks following the victory of the revolution, a group of Islamists with close ties to Khomeini, formed a party, called the Islamic Republic Party. ${ }^{155}$ Khomeini remained aloof from forming any party or affiliating with any party including the Islamic Republic Party. ${ }^{156}$ Formed by staunch supporters of Khomeini, the Party gained attraction amongst the people. In the first day alone, more than eighty thousand people rushed to register as members of the Party. ${ }^{157}$ In the early days of the revolution, the Islamic Republic Party played an important role in settling the narrative of the Islamists while gradually and surely attacking other narratives including those of nationalists and leftists.

155 AXWORTHY, supra note 148, at 145.

156 Maziar Behrooz, Factionalism in Iran under Khomeini, 27 MidDLE EASTERn STUD. 597, 597 (1991).

157 Establishment of Islamic Republic Party, Center for Islamic Revolution Documents, available at http://www.irdc.ir/fa/calendar/180/default.aspx 
The Party also started a newspaper, Islamic Republic, which is still published today. By 1981, and after acerbic defeats for the other groups, the Party held power in all three branches of government. ${ }^{158}$ Soon the Party became factionalized, diverging on critical economic and military issues. In May 1987, Khomeini intervened to issue a decree to abolish the Islamic Republic Party. Since then, Iran has never had strong parties again. ${ }^{159}$

Various groups and forces took part in revolting against the Shah's regime. Yet, despite the variety of these groups and the nuances in their thinking, three categories could be distinguished: leftists, Islamists, nationalists. All three of these groups were at play in the early days of the revolution. Leftists were constantly criticizing the pro-western approach of the Provisional Government and the constitution. They boycotted the constitutional election paving the way for the landslide victory of the Islamists. ${ }^{160}$ However, they marked their critical impact on the revolution with a series of demonstrations that helped the hostage crisis take place in Iran. The left camp struggled for its existence for a few years. Some leftists engaged in guerilla warfare and killings in order to curtail the expansion of the Islamists. Some of them engaged in peaceful opposition spreading their words through press and publications. However, eventually all leftist parties were either eliminated by the Revolutionary Guard, or declared illegal (such as the longest lasting

158 Behrooz, supra note 156, at 598.

$159 I d$. at 600.

160 SEPEHR ZABIR, THE LEFT IN CONTEMPORARy IRAN 97 (1986); KeDdie, supra note 82, at 249. 
leftist party the Tudeh Party) by $1983 .{ }^{161}$ By then, only the Islamic Party and Freedom Party were allowed to legally operate in Iran. ${ }^{162}$

As discussed earlier, Islamists formed an Islamic Republic party, which was believed to enjoy the support of Khomeini. Soon, they became the mainstream voice criticizing the Provisional Government and acted independently of the Government through the Islamic Council and its Committees. During the Bani Sadr presidency, as we will discuss, this party also took the lead in pressing the government. Through the Party, Islamists centralized their efforts and expanded their network. As novices, they also learned collectively how to be involved in politics and use it to advance their goals.

Nationalists or liberals had a short political life span that significantly dwindled with the resignation of Mehdi Bazargan's government in the wake of hostage crisis. Bazargan along with two other political thinkers established the Freedom Party of $\operatorname{Iran}^{163}$ before the revolution in $1961 .{ }^{164}$ The Freedom Party believed in constitutionalism and also believed in the role of religious values in governing. It seemed that at the onset, they shared some leftist and anti-imperialist tendencies that they forwent after the early years of revolution passed. ${ }^{165}$ The leaders and members of the Party suffered from torture, imprisonment and suppression during the Shah's period. After the revolution, they had momentum when

161 KeDDIE, supra note 82, at 254.

$162 I d$.

163 Nehzate-Azadi Iran

164 The other founders were Ayatollah Mahmud Taleqani and Yadollah Sahabi, The Free Movement of Iran, IRAN DATA PORTAL at Princeton University available at http://www.princeton.edu/irandataportal/parties/nehzateazadi/

$165 I d$. 
Bazargan assumed the prime minister position for the transitional government. However, their soft, tolerant, and liberalistic approach did not seem to capture the fervor of the revolutionaries. Also, unlike the Islamic Republic Party, they did not engage in mass recruitment. Instead, they aimed to act as a moderator of the revolutionaries' desire to act radically.

Tensions between the Freedom Party and the Islamic Republic Party culminated in the clash that happened during the Hostage Crisis. While the Provisional Government started to open new avenues with the US, the students stormed the American embassy, making all the rapprochement efforts of Bazargan and his team futile. ${ }^{166}$ Subsequently Bazargan resigned because he stated that the country had a "thousand chiefs." The Freedom Party introduced candidates for the first parliament election. Several of the Party members including Bazargan were elected. The clash between the Freedom Party and the Islamic Party continued in the first parliament. The Islamic Party gradually gained the upper hand, especially after the Freedom Party criticized the war with Iraq and requested that it end following the re-capturing of the occupied territories of Iran. ${ }^{167}$ As a result, the Freedom Party members were banned from candidacy for the second parliamentary election. In 1987, based on an it has remained a marginalized and underground party with seemingly little social base.

166 On November 1, 1979 in Algeria, Bazargan and his foreign and defense minister met with the US national security advisor Zbigniew Brzezinski, ALI GHEISSARI \& VALI REZA NASR, DEMOCRACY IN IRAN: HISTORY AND THE QUEST FOR LIBERTY 94 (2006).

$167 I d$. 
The last bastion that helped Khomeini expand his ideas and network happened through the Cultural Revolution. Again, similar to major events of the early years of the revolution such as the establishment of the Islamic Republic Party hostage crisis, Khomeini did not involve himself in the process. ${ }^{168}$ Evidently, for Khomeini, the revolution of Iran was a "revolution of values". ${ }^{169}$ However, it was not until an initiative by the Council of the Islamic Revolution that the cultural "purge" started in Iran mainly at universities. ${ }^{170}$ It started because some leftists took refuge in university campuses after they were expelled from their headquarters in the summer of $1979 .{ }^{171}{ }^{172}$ Instead of opposing the move, in a surprising turn, Bani Sadr endorsed a cultural revolution in Iran. ${ }^{173}$ Bani Sadr seemingly hoped that he could lead the cultural revolution in a direction to him.. ${ }^{174}$ Soon, however, it became apparent to him that given the organization and the network of the Islamic Republic Party, his effort was destined to fail. ${ }^{175}$ In 1980 ,

168 In several speeches, Khomeini mentioned that the revolution should be exported to the universities.

169 Pardis Mahdavi, Iran's Green Movement in ConteXt IN CUltural Revolution IN IRAN: CONTEMPORARY POPULAR CULTURE IN THE ISLAMIC 13, 19 (2013).

170 KEDDIE, supra note 82, at 250.

$171 \quad I d$.

172 Following the resignation of Bazargan, leftists remained the only viable competitors for Islamists, GHEISSARI \& NASR, supra note 166, at 95.

173 AXWORTHY, supra note 148, at 183-184. It seems that the Islamic Party hoped that Bani Sadr would oppose the ousting of leftists some of whom were his supporters, DILIP HIRO, IRAN UNDER THE AYATOLLAHS 160 (2nd ed., 1987).

174 At the onset the events turned bloody: "on 22 April, instead of trying to stop attacks on 'unIslamic' groups on the campuses, Bani Sadr led a column of Islamic students into the Tehran University campus, and described the day as the start of the cultural revolution. However, since the leftist groups (except the Mujahedin) refused to quit the campuses, pitched battles broke out between them on one side, and revolutionary guards and Hezbollahis on the other. These clashes went on for a few days in Tehran, Tabriz, Isfahan, Shiraz, Mashhad. The official toll was thirtyeight dead and 200 injured." Id. [footnote omitted].

175 Id 
Khomeini appointed seven-members mainly from the Islamic Republic Party to the Council of the Cultural Revolution. The universities were shut down for three years and many leftists and liberal professors and students were dismissed while the curriculum was going through the process of "Islamization". ${ }^{176}$ Again, this event marked another victory for Islamists, which allowed expanding their network and views through universities. ${ }^{177}$

\section{B. Ultimate Arbiter}

Khomeini's idea on the Guardianship of a Jurist is usually recognized as the flagship theory behind the Islamic Republic of Iran and its theocracy. The broad interpretation of the theory bestows ruling, managing, and even legislating functions on the supreme jurist of the Islamic Republic. This interpretation clearly falls under the theocracy category in which a religious leader dictates all aspects of its citizens or to use a better word, governed subjects. The world has witnessed such regimes in Europe during Medieval times and Caliphates during the Islamic empire heyday. The text of the Constitution also gives a strong impression that its mandate is to establish a theocracy. In the introduction, the Constitution says that a fundamental characteristic of the revolution is its ideological

176 KEDDIE, supra note 82, at 250.

177 The purging process was simultaneously happening in the rank-and-file of the government as well: "with the success of the Islamic Republican Party, the process culminated, in late August 1980, in the installation of a group of servile, religiously minded laymen into the prime ministry and other high offices of state. Meanwhile, the IRP's infiltration of lower ranks of the state had been assured by repeated purges of the Westernized elements during the summer 1980. By the beginning of July, after less than ten days of purges, over 1000 functionaries had been discharged. There were some 150 purge committees operating. The purges continued throughout the month of July all around the country. During the last two days alone of major purges at the end of July, some 450 functionaries were discharged. The purges were particularly extensive in [the] Ministry of Education and the army, which were considered strategically crucial from the ideological and military viewpoints. Some 20,000 teachers and nearly 8,000 officers were discharged.", SAID AMIR ARJOMAND, THE TURBAN FOR THE CROWN: THE ISLAMIC REVOLUTION IN IRAN 144 (1988). 
and Islamic feature. ${ }^{178}$ Article 5 of the Constitution establishes that the supreme leader is the successor of the sacred absent Imam of Shiism. Article 57 of the Constitution declares that all three branches of the government perform under the supervision of the supreme leader. ${ }^{179}$ Furthermore, Article 110 of the Constitution contains a long list laying out responsibilities and authorities of the supreme leader. ${ }^{180}$

178 Islamic Republic of Iran Constitution, ISLAMIC PARLIAMENT RESEARCH CENTER, available at: http://rc.majlis.ir/fa/content/iran constitution

179 Art. 57, Id.

180 Art, 110, Constitution of the Islamic Republic of Iran 1979 (as amended on July 28, 1989) WoRLD INTELLECTUAL PROPERTY ORGANIZATION, available at http://www.wipo.int/wipolex/en/text.jsp?file_id=332330 ("The authorities and responsibilities of the leader:

1. determining the overall politics of the Islamic Republic system of Iran after consultation with the Expediency Council;

2. supervising the proper implementation of the general policies of the system;

3. issuing referendums;

4. commanding the armed forces;

5. declaring war, peace, and mobilizing forces;

6. issuing appointments, dismissals, and accepting the resignation of:
a. the jurisprudents of the Guardian Council,
b. the highest position of the judiciary power,
c. the president of the mass media of the Islamic Republic of Iran,
d. the chief of the general staff,
e. the commander-in-chief of the Islamic Pasdaran Revolutionary Corps,
f. the supreme commanders-in-chief of the security and armed forces;

7. coordinating the relationship among the three branches of the government and resolving any conflict among them;

8. resolving issues in the system that cannot be settled by ordinary means through the Expediency Council;

9. signing the appointment of the President of the Republic, after his election by the public. The qualifications of the candidates for presidency, with respect to the conditions set forth by the constitution, must be confirmed by the Guardian Council prior to the general elections and approved by the leader for the first term; 
Yet, this picture seems to be simplistic when we plow through other provisions of the Constitution as well as the unfolded events especially during the early years of the revolution. For one thing, Khomeini's idea of the Guardianship of a Jurist and of statehood has fluctuated through time. In Shia's tradition, ruling was a new phenomenon with little scholarship or experience. ${ }^{181}$ Khomeini started off his political dissidence by simply attacking anti-Islamic elements of the Shah's regime. ${ }^{182}$ He wanted the sovereign to respect Islamic law and abide by it. ${ }^{183}$ However, it was not until exile that he developed a seemingly endogenous political theory. ${ }^{184}$

Khomeini had to bridge from the overly legalistic culture of Shiism to a political one. ${ }^{185}$ He gradually built the theoretical basis for this transition. ${ }^{186}$ First, he proposed that

10. dismissing the President of the Republic, with regard to the best interests of the country, after either the Supreme Court has issued a ruling convicting him of deviating from his legal duties, or the Islamic Consultative Assembly, based on Article 89, has cast a vote against his competence;

11. pardoning or reducing the sentences of convicts, within the framework of Islamic criteria, after the head of the judiciary power has recommended such a motion.

The leader can transfer some of his duties and authorities to another person.")

181 ERVAND Abrahamian, KhomeInism: Essays ON tHe Islamic RePUblic 18-19(1993) ("Throughout the Middle Ages the Shii clergy, unlike their Sunni counterparts, failed to develop a consistent theory of the state."). Due to lack of political theory, for centuries Shii clergies never opined that monarchies were per se illegitimate, Id. at 19.

$182 I d$. at 21. ("for closing down seminaries, expropriating religious endowments, propagating anticlerical sentiments, replacing religious courts with state ones, permitting the consumption of alchoholic beverages and the playing of "sensuous music", forcing men to wear Western-style hats, establishing coeducational schools, and banning the long veil (chador)..."

183 Id.

$184 I d$. at 23. There is a dearth of information on the sources, which inspired Khomeini for his new political theory. Abrahamian believed that possibly the influential sources were Najaf's theological development as well as the leftist literature, Id. at 23-25.

185 In 1970, for the first time, Khomeini delivered his famous speech on Velayat-e-Faqih declaring monarchies as illegitimate and that Muslims should revolt against despotic regimes, Id. at 25.

186 Islam is a religion that is intertwined with rules and guidelines. Understanding Islam inevitably requires understanding the constitutive rules of Islamic Law. Islam has a few primary sources, mainly Quran and Sunna (practice of Prophet Mohammad). Shiism is a school of though 
governing was among the primary tasks of the Prophet. Traditionally, adjudication was considered to be the only or the most important authority of the Prophet. Khomeini enumerated three distinct authorities for the Prophet: 1) Messenger 2) Adjudicator 3) Administer. For the first one, the Prophet solely conveys the message from God. Second, the authority bestows the competency for the Prophet to adjudicate disputes between people in a binding fashion. This authority continued via the Imams of Shia until the $12^{\text {th }}$ Imam, according to Shiism. In fact, one of the important legal sources for Shiism has been the adjudication and judicial opinions of the 12 Imams. ${ }^{187}$ The last authority, however, was new to Shiism. By ascribing this authority, Khomeini endeavored to create a fine line between those orders of the Prophet that were necessary for governing and those judgments that came as a result of adjudication. This approach had two important ramifications for the Shi legal tradition: first, it would allow explaining certain practices and decrees of the Prophet Mohammad that seemed incongruent with main principles. ${ }^{188}$ By following this approach, these outlier opinions would fall under the governing

(Madhab) in Islam which believes that Ali (Prophet Mohammad's son-in-law) was the legitimate successor of Prophet Mohammad. They believe that Ali was the first Imam. Shiism has also different branches one of which is Shiia Isna Ashari, with the largest population in Iran and Iraq. This group believes that there were 12 Imams in total, the last of which disappeared from the face of the earth (Imam Mahdi). They believe Imam Mahdi will return. This school of thought believes that, in addition to Quran and Sunna, the sayings (Hadith) and behaviors of these Imams are also binding on Muslims. Therefore, the body of law created in Shiism is to some extent different from Sunnism. One should bear in mind in Islamic law there is body of law pertaining to inferring primary rules (Osul Figh). This requires a separate discussion but what is important for our purpose is that the absence of last Imam, yet its presence in all times until he returns, plays a crucial role in shaping Shiism political thought. The legitimacy of the supreme leader in Khomeini's view (valiy faghigh) comes from its alleged temporary succession for the 12th Imam.

187 Hossein Modaressi, Crisis and Consolidation IN the Formative Period of Shi'Ite Islam (1993)

188 For instance, in a famous yet conflicting opinion, the Prophet ordered a tree to be eradicated belonging to a person who was constantly bothering his neighbor in order to irrigate his tree. Jurists came up with various explanations for this decision that was clearly in conflict with respect for private property in Islam. 
authority of the Prophet not his adjudication competency. Second, Khomeini believed that the governing authority of the Prophet was later designated to Imams and subsequently to a qualified jurist of each era. This was the bone of contention with other Shi jurists who, unlike Khomeini, did not believe that the governing authority was assignable to any person after the $12^{\text {th }}$ Imam. This was the backbone of the Guardianship of a Jurist theory. 189

At first, Khomeini's efforts were centered on arguing that the Prophet enjoyed another bestowed authority, meaning governing. Later, during the establishment phase of the revolution, Khomeini placed the administrative or governing authority on top of the adjudication role by creating the concept of Maslehat or "expediency". By that concept, he was referring to state interests and it seemed that his theory was the first of its kind to accommodate a main feature of modern statehood, the state of exception. In short, he believed that expediency of governing could even suspend the primary rules of religion. For instance, destroying a mosque is not permitted. Yet, if due to state interest, a mosque needed to be torn down, through the notion of expediency emanating from the administrative authority, the mosque could be destroyed. ${ }^{190}$ This idea embodied the Expediency Discernment Council, which came to existence by Khomeini's decree in

189 Khomeini had to confront traditionalists who at most believed in constitutional monarchy. The most famous dissident of Khomeini's political theory was Ayatollah Shariatmadari. For more on his opinions see KEDDIE, supra note 82, at 194-195.

190 David Menashri, Iran in Middle East Contemporary Survey 341, 346 (Bruce MaddyWeitzman ed., vol. 21, 1997). 
1988. In the order, Khomeini stipulated, “...the state's interest is a critical issue, ignoring of which would sometimes result in a defeat of dear Islam.”191

There is a wide spectrum of ideas and speculations about what Khomeini had in mind on ideal governing. In fact, these speculations have remained until today and have caused several factions to emerge within Iranian politics. We hear many labels for Khomeini's political theories, from sultanism, ${ }^{192}$ the king philosopher regime, ${ }^{193}$ to religious democracy. ${ }^{194}$ Yet, scholars tend to focus more on the events, Khomeini's speeches, violent incidents during the post-revolutionary period, and the suppression of dissidents including the left. Nevertheless, focusing on the Constitution, as keenly observed by Abrahamian, “...the whole constitutional structure of the Islamic Republic was modeled less on early caliphate than on de Gaulle's Fifth Republic." ${ }^{195}$ The role of the supreme leader was more of an arbiter than an authoritarian dictating all governmental affairs and policies. Khomeini also carried out his position as more of a political arbiter and a conciliator for political disputes than a rigid fundamentalist waiting for opportunities to implement another rule of Islam. This partly explained why "Khomeini, despite his denials, was highly flexible, remarkably innovative, and cavalier toward hallowed traditions." 196197 For him, the leader was a political position rather than a religious one.

191 Establishment of Expediency Discernment Council, IsLAMic Revolution Document CENTER, available at http://www.irdc.ir/fa/calendar/81/default.aspx.

192 E.g. Akbar Ganji

193 E.g. Milani

194 e.g. Khatami (former president of Iran).

195 ABRAHAMIAN, supra note 181, at 15.

$196 I d$. at 17. 
Any analogy of the post-revolution regime of Iran to the Papacy in the Middle Ages, the caliphate era, or the Sultan dynasties does little to help in comprehending the complicated and ambiguous political ideas of Khomeini. This constitutional role did not come solely as a result of Khomeini's thoughts and theory about the Guardianship of a Jurist. In fact, he never proposed the theory to be included in the Constitution. It was others who pursued it. ${ }^{198}$ Furthermore, in the tumultuous times of the early years of the revolution and given his charisma, Khomeini was referred to for thorny decisions related to incidents such as the hostage crisis, the Bani Sadr presidency, war. This tradition has continued to this today with noticeable nuances that the supreme leader position was designed to break political gridlocks by acting as an ultimate arbiter.

\section{Emergence of Dualism}

Vali Nasr in his book, Forces of Fortune, argues, "Iran's constitution is an unhappy mix of Islamic government and popular sovereignty..." 199 and continues to assert that "Iran does not have one government, it has layers of government." 200 These are true statements, yet it seems that it is precisely the "unhappy mix" and "layers of government" features

197 Mohsen Milani gives a similar account of Khomeini: "Khomeini alone called the important shots and determined the direction and tempo of change. When opposed, he expeditiously consolidated his rule; when strongly opposed, he retreated, regrouped, and struck back. Most important, he had a clear vision of what he hoped to accomplish and suffered from no inferiority complex toward either his opponents or his Western enemies." MILANI, supra note 49, at 145-146.

198 E.g. Ayatollah Montazeri

199 NASR, supra note 79 at 58.

$200 \quad I d$. at 59. 
that have kept constitutionalism alive in Iran. These features have remained more or less consistent in the past 35 years since the Iranian Revolution.

The early days of the revolution established what soon became a critical feature of the Islamic Republic of Iran's constitutionalism. Unlike Nehru and Mandela, Khomeini recused himself from day-to-day operations of the revolution and delegated it to the Provisional Government (executive arm) and the Revolutionary Council (legislative arm). His efforts established himself and his role as the grand strategist and the conciliator for the revolution. This was discussed in the previous section. Another important feature of constitutionalism in Iran was developed due to the dualist nature arising from the tensions between the Supreme Leader role and the elected government officials. The first tension arose between the Bazargan government and the Islamic Republic Party. The Bazargan provisional government was not elected by the people but by the Revolutionary Council. Yet, Bazargan's government was a harbinger of dualism in Iran. ${ }^{201}$ After a long and attritional battle with the Islamic Republic Party on various aspects of governing, he finally voiced his frustration: "unless this [duality of power] is rectified and resolved, the mere election of a president and election of [parliamentary] representatives will not be enough."202

By duality, Bazargan was referring to the mini state, which the members of the Revolutionary Council had created. ${ }^{203}$ Bazargan was clearly unhappy with the clerics

201 The assassination of Ayatollah Motahari struck a major blow, as he was a mediator and a conciliator between Islamists and liberals. KEDDIE, supra note 2, at 245.

202 Quote from Mehdi Moslem, Factional Politics in Post-Khomeini Iran 25 (2002).

203 Id. at 24. 
gradually taking over political matters. Islamists and Khomeinists had the control of the Revolutionary Council and started to implement executive affairs through their committees. ${ }^{204}$ They also gradually dominated the judiciary system and executed many of the political and army officials of the Shah's regime. ${ }^{205}$ Bazargan finally resigned. The resignation was quite likely due to the duality of the government. Yet, it came at a critical turn in the post-revolution phase: the hostage crisis. While Bazargan was seeking rapprochement with the US, "Students following the Line of the Iman" stormed the US embassy and took the staff of the embassy hostage. As far as we know, Khomeini did not know of this plan and did not approve it at the beginning. ${ }^{206}$ Yet, seeing the wave of support for it, Khomeini turned it in his favor and quickly capitalized on this event. ${ }^{207}$ This incident had at least two important impacts in the history of Iranian constitutionalism: It established the supreme leader as the "to-go-person" for critical decisions of foreign policy. Second, it weakened the liberal groups and those who had wanted to improve the relationship with the West for a long time. In fact, it created a narrative for those who supposedly stood for "independence" versus those who were soft and preferred to rely on Westerners. The legacy of hostage crisis has yet to be explored but it further entrenched the built-in dualism of the Iranian new political order, but this time in the foreign policy arena.

204 KEDDI, supra note 82, at 245.

$205 I d$., at 245-246.

206 US officials at the time had a completely different view. They believed either Khomeini had approved the take-over or at least had foreknowledge of the hostage seizure, BABAK GANJI, POLITICS OF CONFRONTATION: THE FOREIGN POLICY OF THE USA AND REVOlUTIONARY IRAN 150 (2006).

207 Id., at 248-249. 
To the surprise of many Khomeini accepted Bazargan's resignation after a meeting with Revolution Council members. ${ }^{208}$ Almost ten years later, Khomeini mentioned in a letter that he was against the appointment of Bazargan but he was a good person. ${ }^{209}$ It was possibly a political maneuver especially since at the time the Freedom Party was marginalized and under constant attack by the Islamists. ${ }^{210}$ Bazargan's government was a “good government for a wrong time". ${ }^{211}$ During a tumultuous time of post-revolution, the government was soft while unaware of the ways to establish and grow its social base. ${ }^{212}$ It could not compete with the networking capability of the Islamists.

Bani Sadr's story was different from Bazargan. He won the election with a landslide (76\% of the votes) while running as an 'independent' candidate. The Islamic party suffered a major defeat in the election. During the early years of the revolution, Khomeini forbade members of the clergy to run for executive posts. When it came to the first presidential election, Khomeini explicitly banned clerics from running for presidency. ${ }^{213}$ This helped Bani Sadr in his landslide victory as Khomeini banned Ayatollah Beheshti, a leading figure of Islamic Party, from running for the presidency. ${ }^{214}$

208 BAQER Moin, KHOMEINI: LIFE OF THE AyATOLLAH 221 (2000).

209 http://jahannews.com/vdccoeq1p2bq048.ala2.html

210 Khomeini allegedly tore a letter from Bazargan that he sent regarding unnecessary prolongation of Iran-Iraq War. Reportedly he did like the fact that the letter did not start with "in the name of God" and also referred to the revolution as "Iranian Revolution" and not "Islamic Revolution.

211 MiLANI, supra note 49, at 141.

$212 I d$. at 144.

213 KEDDIE, supra note 82, at 249. "The IRP [Islamic Republic Party] ended up supporting an obscure candidate who got only 700,000 votes.", Id.

214 The Islamic Party quickly moved to support a non-cleric candidate, Jalalodin Farsi. Yet, the opposition declared that he was not of Iranian origin, only a week from the election. The Islamic Party reluctantly supported the candidate of the Freedom Party. 
Bani Sadr was an obscure figure. His name definitely was not among the top revolutionaries. ${ }^{215}$ However, people gradually learned about him when he appeared as a member of Khomeini's entourage after his return to Iran. He met with Khomeini for the first time when he was in Iraq. ${ }^{216}$ He quickly turned himself into a political and religious thinker by publishing two books and supporting Shariati, a leading and widely popular theorist before the revolution. ${ }^{217} \mathrm{He}$ belonged to a group of non-clerics who studied outside of Iran. Before the presidency, Khomeini appointed him to the Revolutionary Council. ${ }^{218} \mathrm{He}$ was an economic secretary in the Bazargan administration ${ }^{219}$ and also an opponent of the theory of the Guardianship of the Jurist in the Constitutional Assembly. Yet, it was widely believed and uncontroversial that Khomeini supported Bani Sadr in the first presidential election. Khomeini's alleged support acted as a critical factor in his victory in the election.

The support for Bani Sadr continued. Khomeini appointed him the head of the Revolutionary Council and the army. ${ }^{220}$ Yet, disgruntled Islamic Party members quickly

215 "He pursued his university education in Tehran, specializing in economics, sociology and the Sharia. He had been in the capital for about a decade when the June 1963 uprising occurred. He was jailed for four months for this participation in a demonstration. After his release, a scholarship took him to the Sorbonne University in Paris. He gained a doctorate there, and stayed in Paris until the revolution in Iran." DiLIP HIRO, IRAN UNDER THE AYATOLLAHS 148 (1985).

216 He went to Najaf in Iraq for his father's funeral, $I d$.

217 http://www.rahesabz.net/story/71832/

218 Khomeini seemed to like Bani Sadr because his uncompromising stance towards the Shah and Shahpour Bakhtiar, HIRO, supra note 215.

219 Bani Sadr was a critical figure in setting the economic policies of the post-revolution Iran, Id. at 148.

220 The conservatives in Iran do not see these appointments as support for Bani Sadr. They view it as Khomeini's support for democracy and his respect for people's votes, see http://www.imam-

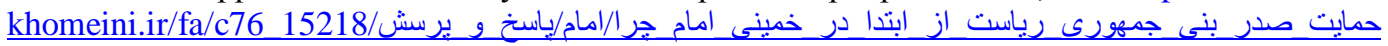
كر دند؟ 
recovered and aimed for a sweeping victory in the parliament. They succeeded and won the majority seats in the first parliamentary election in the Islamic Republic of Iran. Bani Sadr realized that the Islamic Party would try to contain his powers and limit his authority. He first claimed the election was rigged. Later, he tried to avoid Parliament and bypass it in any way possible. For instance, he would avoid signing bills into law albeit the fact that in the constitution no veto power was stipulated for the president. ${ }^{221}$

Bani Sadr clearly wanted to consolidate powers in his hands. His aim was to create a presidential system, while other political bodies, including parliament, was of secondary importance. His education in France and his encounter with the fifth republic might have influenced his approach. Some believe it was his personality that steered him to vie for more power. ${ }^{222}$ However, his tragic fate was predictable: unlike the Islamic party he did not have a network or strong social base. ${ }^{223}$ He had Khomeini's support for a long time but it proved not to be enough especially after the Islamic Party convinced many that Bani Sadr was "incompetent." Later, Khomeini swore that he did not vote for Bani Sadr. His political demise also was due to his mistakes, his indecisiveness, along with two major events: the hostage crisis and the Iran-Iraq War. Eventually, Bani Sadr was impeached and Khomeini confirmed impeachment by the Parliament. Bani Sadr's fate enfeebled the status of the presidency in Iran's Constitutional culture. The army was also

221 http://www.rahesabz.net/story/71832/

222 http://www.rahesabz.net/story/71832/

223 Towards the end of his presidency he had to resort to Mojahedin's party and network. In fact, he hid in their hideout in Tehran when opposition to him reached its peak. 
taken away from the president, following a controversy over Bani Sadr's inactions in the Iran-Iraq war.

Upon his assumption of the presidency, Bani Sadr showed determination to solve the Hostage Crisis himself in order to establish his stature in the political scene of the time..$^{224}$ Previously as a member of the Revolutionary Council, he opposed the take-over of the embassy. ${ }^{225}$ Now, as the head of the Council he wanted to take matters into his own hands. However, in every move, Khomeini took sides with the students not with him. Bani Sadr pursued a UN commission to visit Iran in order to meet with the hostages in the hope that Iran could receive compensation for its grievances in exchange for the hostages. ${ }^{226}$ Khomeini did not agree and a few student supporters of Bani Sadr left the embassy. ${ }^{227}$ Bani Sadr had to give up on his plan. ${ }^{228}$

With the start of the Iran-Iraq war, Bani Sadr devoted his attention to the war zones. For him, victory on the battlefields would mean victory in the complicated politics in Tehran. He wanted to garner all the credit for victories and did not like to share it with anyone else. This is the reason behind his skepticism towards utilizing the Revolutionary Guards as an organization with close ties to the Islamic Party. To this day, even among existing

224 "He asked for twelve-month mandate from Khomeini to accomplish the following tasks: solving the American hostage crisis; stabilizing the economy; resolving the minorities' problems, particularly the Kurdish rebellion; and reconstructing the armed forces. But, Khomeini did or said nothing specific in return." HIRO, supra note 215 at 149 (1985).

225 Some claim that it was the disagreement between Bani Sadr and Ghotbzadeh in the Revolutionary Council that prolonged the hostage crisis to 444 days, see http://www.rahesabz.net/story/71832/

226 HIRO, supra note 215, at 149; KEDDIE, supra note 82, at 251.

227 HIRO, supra note 215.

228 Later and subsequent to the Algiers Accord, Bani Sadr criticized handling of the situation by Islamists. Despite Iran claim that it was victory for it, the agreement was more favorable to the US than Iran, KEDDIE, supra note 82, at 252. 
commanders of the Islamic Republic of Iran, there is disagreement on Bani Sadr's wartime strategy, its benefits, its disservice and the intention behind it. ${ }^{229}$ Yet, a major defeat paved the way for the Islamic Party to further pound on their narrative: Bani Sadr was incompetent. ${ }^{230}$

A final event struck the fatal blow to Bani Sadr's political career. Bani Sadr publicly denounced the handling of the hostage crisis. During his speech, violence broke out and he ordered the police to arrest the Islamists. Khomeini intervened and ordered that a reconciliation committee be established. He demanded both sides, meaning Bani Sadr and the Islamic Party, stop fighting until the committee reached its decision. Khomeini also banned them from delivering any public speeches and also interviewing until the decision was announced. Bani Sadr did not wait for the decision and continued criticizing his prime minister, Rajai, who had the support of the Islamic Party. Subsequently, his newspaper was closed, the Parliament impeached him and Khomeini dismissed him from the commander-in-chief position. ${ }^{231}$ Bani Sadr hid for a while until he left Iran in disguise and went to Paris. With the political demise of Bani Sadr, the window for a powerful presidency was closed for a while. The next presidents did not create major tensions. The war had an important impact in marginalizing political life in Tehran. The devastation and economic hardship imposed by wartime conditions did not leave much room for the

229 http://www.bultannews.com/fa/news/61284/تحميلى-جنغ_در -صدر-بني_هاى-خيانت

230 For details on this defeat see, Williamson Murray \& KEVIn WoOds, ThE Iran-IRAQ WAR: A Military AND StRATEGIC History 143-145 (2014).

231 KEDDIE, supra note 82, at 252. 
political arena. It was not until the amendment of the constitution that we witnessed a powerful presidency again. Dualism re-emerged again after Khomeini.

\section{End of Charisma: Institutionalizing}

The last years of Khomeini's leadership were critical in shaping the Islamic Republic of Iran as we know it today. Still, many ambiguities exist regarding the political incidents of that period. This is partly because the events leading to the appointment of the successor of Khomeini have remained confidential and controversial. It also has not been 
thoroughly studied, especially from a constitutional perspective. This period led to what

some scholars call Iran's "second republic", ${ }^{232}$ borrowing the language from the phases in

French constitutional development. Whether Iran became more democratic and "republic" after the succession phase remains highly controversial. This uncertainty renders the analysis of the succession period necessary and vital for understanding the nature of one of the most important political orders in the Middle East.

\section{A. Rift in Iranian Politics}

The dismissal of Bani Sadr paved the way for the supporters of Khomeini and the Islamic Republic Party to have a monopoly in Iranian politics. Unlike the first parliament, the second parliament did not have members of parties which were on the opposite side of the policies of the Islamic Republic Party. The National Party was found to be a heretic party, the leftist parties were ousted from politics and the Freedom Party was

232 See generally Anoushiravan Ehteshami, After Khomeini: The Iranian SeCond Republic (2002). Some authors believe that the third republic started with the election of reformist president, Mohammad Khatami, Ghoncheh Tazmini, Khatami's Iran: The Islamic Republic and the Turbulent Path to Reform (2009) ("Khatami's election marked the beginning of the third Islamic republic. Enthusiasm for the election must be understood in the context of the fundamental social changes of the first and second republics. The first republic was formed in the immediate aftermath of the 1979 revolution, and had at its core Ayatollah Khomeini's use of social mobilisation to unite the masses and guarantee the continuation of the state during the heady days of the Iran-Iraq conflict. The second republic began at the end of the Iran-Iraq War in 1989 and was principally guided by new economic realities and wider strategic considerations. The second republic is associated with Ali Akbar Hashemi Rafsanjani's eight-year presidency following Khomeini's death in July 1989." 
marginalized following the impeachment of Bani Sadr. The election became a scene for the Islamisists to compete against each other. ${ }^{233}$ The second parliament election happened when the eight-year Iran-Iraq war started.

War with Iraq had an undeniable impact on Iranian politics. Managing the war required more homogenous elites. In other words, war paved the way for a more top-down authoritarian political order. The isolated Iran faced a long and brutal war without having significant support from the outside. ${ }^{234}$ On the other hand, Iraq increasingly gained logistical and military help from different countries including, towards the end of the war, the United States. ${ }^{235}$ This further cemented the anti-Western and anti-imperialist attitude in the mind of Khomeini and his supporters. As some scholars noted, the anti-American rhetoric of Khomeini became augmented, even more than that following the Hostage incident. $^{236}$

Managing the war on the one hand and ideological differences on the other finally created friction amongst the supporters of Khomeini and Islamic Republic Party members. Soon,

233 Morteza Kazemian, Reviewing Eight Parliamentary Elections in Islamic Republic of Iran, BBC Persian, Dec. 23, 2011, BBC Persian available at http://www.bbc.co.uk/persian/iran/2011/12/111221_139_majlis9th_8-terms\#second

234 In fact Iran's isolation was amongst the factors that was in Sadam's calculation to attack Iran, ROB JOHNSON, THE IRAN-IRAQ WAR 44-45 (2011)

235 Besides a brief moment change of policy because of Israel's preference for Iran's victory, the United States supported Iraq diplomatically and militarily for most of the Iran-Iraq war: "The United States helped Iraq by maintaining its arms embargo on Iran, protecting shipping in the Gulf, providing weapons and intelligence, and mounting a counterterrorist campaign against Iran. The tilt toward Baghdad was briefly countered by an Israeli-encouraged arms deal in which Reagan Administration thought it was providing some spare parts and TOW and HAWK missiles in exchange for help in the release of Americans held hostage by Hizballah, Iran's surrogate in Lebanon, and the promise of talks with so-called Iranian 'moderates."', Judith Yaphe, Changing American Perspectives on the Iran-Iraq War, in THE IRAN-IRAQ WAR: NEW INTERNATIONAL PERSPECTIVES 178, 178 (Nigel Ashton \& Bryan Gibson eds., 2013).

236 Mehran Kamrava, Khomeini and the West in A CRITICAL InTROduction to KHOMEINI 156-157 (2014). 
divergent views emerged in regard to important issues in the politics of Iran. One fault line was the level of states' intervention in the economy. A group believed in the minimal intervention of states considering the sanctity of private property in Islam. The other, including the prime minister, Mir Hussain Mousavi, advocated the expansive state control of the economy especially during the difficult time of war. ${ }^{237}$ Another critical issue pertained to the role of Islam in the society. It was clear for the supporters of Khomeini following his teachings that Islam should be at the center of the new regime.

Divergent views, however, resurfaced regarding the nature of Islam and its role in society and politics. One faction favored the traditional view of Islam, which included implementation of Sharia rules and continued support for the link between the bazaris (businessmen) and clerics. They, however, disapproved the exportation of the Iranian revolution to other countries. The other faction had a more radical view of Islam: they were not fans of bazaris, they supported the exportation of Islam and the Iranian Revolution to other countries, and they believed in the role of the poor and dispossessed class in the Islamic Revolution. Rightly so, the first group is identified as the right and the second group as the left in Iranian politics. ${ }^{238}$ Hosein Bashiriyeh, a political sociologist calls this "cleavage" a friction between "populist Khomeinists" versus "Conservative

237 Mehdi Moslem, Factional Politics in Post-KhOMEINI IRAN 47-48 (2002).

238 Id. Influential members of right at the time included Ayatollahs Mohammad Reza Mahdavi Kani, Ahmad Janati, Mohammad Imami Kashani, Ahmad Azari Qomi. In the left camp, the influential figures were Mir Hussain Mousavi, Behzad Nabavi, Mohammad Mussavi Khoeiniha, Mehdi Karoubi, Ali Akbar Mohtashami, Ayatollah Mousavi Ardabili, Ayatollah Mohammad Beheshti, and Hossein Ali Montazeri, id. 
Traditionalism". ${ }^{239}$ The difference between these two camps also existed in their theoretical approaches to the interpretation of Islam. The conservative group espoused traditional methods in construing Islamic texts. The other group advocated the dynamic interpretation, which meant Islamic rules should be updated in accordance with the needs of each period of time. ${ }^{240}$ This rupture in the Islamic bloc, eventually led to the dysfunction of the Islamic Republic Party. Eventually in 1987, Rafsanjani and Khameini asked Khomeini to dissolve the party to which he agreed.

As a result of this rift in Iranian politics, Khomeini became the arbiter for political fights between these two major factions. Interestingly enough and especially towards the end of his life, Khomeini was siding more with the left (populist Khomeini) camp against the traditional Islamists. ${ }^{241}$ One of the first instances of Khomeini's intervention dates back to 1981 where the Council of Guardians vetoed a land reform bill on the ground that it would violate the right to private property. Rafsanjani, the Parliament Speaker at the time, asked Khomeini to intervene in the matter because of the principle of expediency in Islam. Khomeini refused to address the matter directly but in a letter he praised the dynamic approach to Islam that allows for Sharia to be compatible with the needs of a

239 Hossein Bashiriyeh, Cleavages in Iranian Politics Since 1979, in Politics \& CUltuRE IN CONTEMPorary IRAN: Challenging the Status Quo, 33, 42-43 (Abbas Milani \& Larry Diamond, eds., 2015). ("The process of power consolidation by the revolutionary regime maybe understood as a process of "cleavage breaking" or cleavage inactivation.")

$240 \quad I d$. at 41.

241 Id. at 44. ("Khomeini, as the supreme leader, initially sought to act as an arbiter of the unfolding disputes, but during the last two years of his life, he clearly took sides along the same main cleavage, criticizing the conservative clergy as "reactionaries" and supporting the populist groupings, by issuing a number of decrees.") 
society. ${ }^{242}$ In another important example, the parliament sought Khomeini's advice because of a gridlock deriving from political rivalry between the president, Khamenei, and the prime minister, Mousavi. The president believed that the constitution granted him the power to appoint or dismiss a government. Therefore, he argued that it was him who should have the authority to nominate a prime minister. The parliament, with the left holding the majority, did not like Khamenei's choices for the prime minister position. As a result, Khamenei took no action for a while until the members of the parliament wrote a letter to Khomeini asking him to intervene in this matter. He did not address the matter directly but praised Mousavi, the Prime Minster, in his letter. As a result, Khamenei, despite his preference, nominated Mousavi. ${ }^{243}$ The last occasion that is worth noting relates to an unprecedented letter Khomeini wrote to the president, Khamenei, warning him that he did not understand the theory of Guardianship of a Jurist (velayate faghih). This letter came against a backdrop of another tension between disgruntled conservatives in the Council of Guardians and the left camp in the government. Khamenei in a Friday prayer speech stressed that the government should stay within the boundaries of Islamic law. However, subsequently, Khomeini wrote a harsh letter rebuking Khamenei. In the letter Khomeini emphasized that the state can override Sharia rules if they are contrary to the interests of the country or Islam. ${ }^{244}$

242 SAID Amir ArJomand, After KHOMEINI: IRAN Under His SUCCESSOR 31 (2009).

243 MOSLEM, supra note 237, at 66.

244 "The state that is a part of the absolute vice-regency of the Prophet of God is one of the primary injunctions [ahkam-e avvaliyeh] of Islam and has priority over all other secondary injunctions, even prayers, fasting, and haj'. The ruler is authorized to demolish a mosque or a house that is in the path of a road and to compensate the owner for his house. The ruler can close down a mosque if need be, or can even demolish a mosque that is a source of harm if its harm cannot be remedied 
In summary, the tension between conservatives and populists is critical in understanding the politics of Iran after Islamists took control of the leadership. This dynamic between these two groups played a definitive role in the succession period following Khomeini's death. Furthermore, many political factions that later surfaced in Iranian politics also came as a continuation of this first rift in Iranian politics. ${ }^{245}$ Bashiriyeh believe that two pivotal issues fostered the political-ideological space in Iranian politics: one pertains to the dispute over economic regulation and the other is related to modernization and liberalization. ${ }^{246}$ However, as noted by him, neither of these political factions has created a stable party system in Iran so far. ${ }^{247}$ In the next section, we will focus on the succession crisis and the constitution amendment.

without demolition. The state is empowered to unilaterally revoke any Shari'a agreement that it has conducted with people when those agreements are contrary to the interests of the country of Islam.", Id. at 74.

245 "Traditionalist-conservatives considered the tradition of Islam as superior to the Revolution and its leadership; for them, everything came from that tradition. By contrast, Khomeinists argued that the Revolution was a novel and unique event; for them everything came from the mass revolution, so that the tradition of Islam had to somewhat adjust itself to its requirements - whence the importance of absolutist theocracy. On the other hand, modernist neoconservatives emphasized the need to go beyond both a restricted-traditional Islam as well as the requirements of a mass revolution and to reconstruct the country as a stable, modern Islamic nation. Democratic reformism has more specifically advocated the establishment of a stable, modern Islamic democracy based on a stronger notion of popular sovereignty. Finally, new fundamentalism, as a sort of radicalized conservatism reacting to modernization and democratization, has advocated a combination of some elements of traditionalism and Khomeinism.", Bashiriyeh, supra note 239, at 66.

$246 I d$. at 65.

$247 I d$. at 66. ("For several reasons, cleavages have been emerging within the polity, and the central ruling groups have sought to obliterate or diminish their political impact by preventing rival parties from participation in power. As a result, political cleavages have been too unstable and fluid for the rise of a stable party system." 


\section{B. Succession Crisis}

The succession phase in the Islamic Republic of Iran started with Iran's acceptance of the United Nations Security Council Resolution 598. This Resolution called for the end of the Iran-Iraq war. Khomeini was not in favor of ending the war and he famously mentioned that he finally agreed to drink the "poison chalice" in his long declaration about the end of the war. ${ }^{248}$ His decision came after reportedly a series of sessions and letters by army generals warning him about Iran's diminishing military capacity and Iraq's acquisitions of new weapons and more sophisticated tactics. ${ }^{249}$

The end of the war created some apprehension regarding the Khomeini's succession. It coincided with Khomeini's worsening health condition. He was eventually hospitalized in $1988 .{ }^{250}$ Important incidents following the end of the war all have direct and indirect reverberations on the succession matter. One critical development was the clash between Khomeini and Montazeri. Ayatollah Montazeri was an important figure in Iranian politics and a former student of Khomeini. He was a staunch supporter of the theory of

Guardianship of a Jurist and an influential force behind its incorporation in the Constitution of 1979. In 1985, he became the official deputy of the supreme leader and

248 "I reiterate that the acceptance of this issue is more bitter than poison, but I drink this chalice of poison for the Almighty and for His satisfaction.", BAQER MOIN, KHOMEINI: LIFE OF THE AYATOLLAH 269 (1999).

249 See e.g. the letter of Revolutionary Guard commander, Mohsin Rezai: "If we deploy 350 infantry brigades and purchase 2,500 tanks, 3,000 artillery pieces, 300 warplanes and 300 helicopters, and master the manufacture of a substantial arsenal of laser and nuclear weapons which by then will be among the necessities of modern warfare, then God willing, we can think of going on offensive.", JAMES BuChan, DAYs OF God: The REVOLUTION IN IRAN AND ITS CONSEQUENCES 318-319 (2012).

250 MoIN, supra note 248, at 270. ("In the last months of his life his failing eyesight made him more dependent on his children, Ahamd and Zahra, and on Ahamd's wife Fatemeh, to read newspapers, official reports and books for him.") 
Khomeini's successor. More importantly, he was a leading Islamic jurist, a qualification that all Khomeini's inner circle lacked. However, Montazari was never amongst the main aides of Khomeini and never attempted to become a member of Khomeini's operation wing. ${ }^{251}$ Increasingly his role became that of a moral authority without any systemic influence on any decision-making. ${ }^{252}$

It was perhaps because of Montazeri's aloofness from the operational circle of elites that he became increasingly vocal in criticizing many aspects of government. ${ }^{253} \mathrm{He}$ publicly voiced his dissatisfaction on issues ranging from managing the war to day-to-day operation of the government. ${ }^{254}$ During 1988 , he delivered lectures in Qom criticizing that the country had become a dictatorship and the political parties were not influential in the politics. ${ }^{255}$ However, his two letters to Khomeini shockingly revealed the differences between the two and put an end to his participation in the governance of Iran. In those letters, Montazeri harshly criticized the practice of the mass execution of dissidents of the Islamic Republic of Iran as well as the practice of exporting the revolution to other

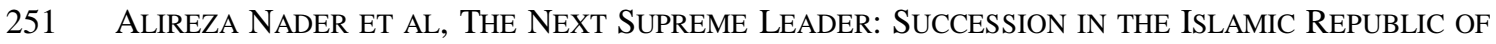
IRAN 37 (2011).

252 "He held no office except the title of deputy leader and had, therefore, only moral influence as the most senior revolutionary clergyman after Khomeini. Moreover, the most important responsibility Khomeini had delegated to him - the task of supervising, in the difficult circumstances of postrevolutionary violence and chaos, recommendations for the pardon of prisoners-often brought him into conflict with the intelligence apparatus, the Revolutionary Courts, the judiciary, and a whole web of vested interests.", MoIN, supra note 248, at 277.

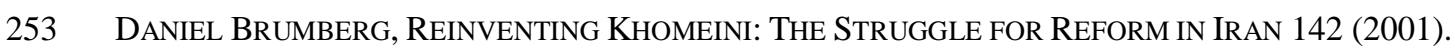

254 Unspoken Words of Hashemi about the Dismissal of Ayatollah Montazeri, available at:

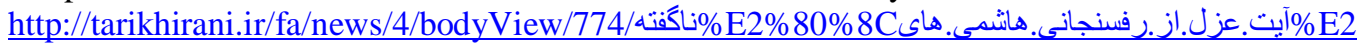

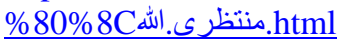

255 MoIN, supra note 248, at 277. 
countries. ${ }^{256}$ Following the unsuccessful attack by the opposition group, People's Militants, from the Iraqi borders, around 3000 political prisoners were executed in the span of only two months.

Montazeri's open and unprecedented criticism on the one hand, and the arrest of his family members in conjunction with espionage allegations, ${ }^{257}$ made it easy for contenders to eliminate this last barrier to the successor position to Khomeini. Following these incidents, the Council of Experts signaled to Montazeri that he should resign from his deputy and successor position to the supreme leader. He resigned and returned to Qom to focus on his teaching. Nevertheless, he became the voice of opposition in the years to come leading to his house arrest. Many of the influential figures in the Reformist camp that surfaced following the election of Khatami, were students or supporters of Montazeri's ideas. It is still controversial whether it the plan was concocted by the inner circle of Khomeini with the help Khomeini's son or whether it was his personal choice since the letters were unprecedentedly harsh and personal. In those letters Khomeini called Montazari a "gullible" and easily influenced person who had been played by liberals and foreigners. He disowned him by declaring that from the beginning he was opposed to his appointment as the deputy to the supreme position but did not want to

256 NikKi Keddie, Modern Iran: RoOts And Results of Revolution 260 (2003).

257 This incident is sometimes referred to as "Irangate": "The "Irangate" episode had caused deep animosity between Montazeri and his entourage and the government team (including Rafsanjani, Khamenei, Velayati and Karrubi, amongst others) which had led to the secrete contacts with the United States and Israel. That Montazeri had been regarded by the Rafsanjani-Khamenei axis as an obstacle in their way cannot, therefore, be overemphasized in the context of succession struggle.", EHTESHAMI, supra note 232, at 32. 
interfere with the affairs of other institutions. ${ }^{258} \mathrm{He}$ even went further to say that he was against the appointment of Bazargan as well as the election of Banisadr. ${ }^{259}$

Khomeini made two moves both of which had important international reverberations during his last year partly in order to signal to Montazeri and the traditionalists that the Islamic Republic of Iran should be active in exporting Islam and its revolution. First he sent a letter, in January 1989, to Mikhail Gorbachev inviting him to join Islam because, he declared, communism soon would belong to the museum of history. Gorbachev wittingly responded that he felt honored to be the only leader to whom Khomeini wrote a letter. ${ }^{260}$ In the second move, in February of 1989 , he issued a fatwa (religious verdict) calling Salam Rushdi, the author of Satanic Verses, an apostate and invited Muslims to fulfill the execution wherever they found him. ${ }^{261}$ In all these moves, Khomeini was flexing muscles against opponents to further establish his position, which can be called the interest-oriented approach to governance. His idea became embodied in the extra constitutional Expediency Council, which eventually entered the Constitution in the amendment of 1989. We will discuss this matter in the next section.

258 "I swear to God that from the start I was against choosing you as my successor, but at the time I did not realize you were so gullible". MoIN, supra note 248, at 288.

259 "I swear to God that I was against appointing Mehdi Bazargan as the first prime minister, too but I considered him to a decent person. I also swear to God that I did not vote for Bani Sadr to become president either. On all these occasions I submitted to the advice of my friends.", MoIN, supra note 248 , at 289.

260 MoIN, supra note 248, at 274-275.

261 Daniel Harmon \& Anne Todd, Ayatollah Ruhollaj Khomeini 78-79 (2005). ("Perhaps he really believed it. Some have conjectured, though, that the death sentence again Rushdie was a public relations ploy. They suggested that Khomeini took this opportunity to portray himself as the foremost defender of his faith. He still hoped the revolution he had ignited might spread to other Islamic countries."); Bernard Lewis believed that the fatwa was a significant depart from Islamic tradition on the issue of blasphemy which should be adjudicated in front of a court, BERNARD LEWIS, THE CRISIS OF ISLAM: HOLY WAR AND UNHOLY TERROR 141-142 (2004) 
With the removal of Montazeri from the political scene, the floor became open for others to vie for the position. On the other hand, it created a void in the politics of Iran. The characteristics required under the Constitution for the supreme leader position fitted Khomeini. Per the Constitution, the supreme leader of the Islamic Republic of Iran should be a source of emulation (Marja Taghlid) as recognized by the people. However, after the assassination of Ayatollah Beheshti, and Ayatollah Motahari by opposition forces, defrocking Ayatollah Shariatmadari by Khomeini and the dismissal of Ayatollah Montazeri, no leading Islamic jurist remained in power to be a viable successor to Khomeini. The Constitution predicted establishment of the council of leaders in case the people found no major Islamic Jurist that matched the criteria stipulated in the Constitution. However, this alternative was not appealing to the ruling elites of Iran, as they feared chaos and disarray in the leadership and in people's obedience of its decrees. Therefore, Khamenei (president), Rafsanjani (house speaker), Mousavi (prime minister), and Ardebili (head of the judiciary) wrote a letter to Khomeini asking him to issue a decree regarding the amendment of the Constitution. ${ }^{262}$ The 1979 Constitution of Iran did not stipulate any process by which the Constitution could be amended. In response to the request, in 25 April 1989, Khomeini wrote a letter establishing the Constitution Review Council comprising of 25 members, 5 appointed by Parliament and the rest appointment by himself. ${ }^{263}$

262 BRUMBERG, supra note 253, at 143.

263 MoIN, supra note 248, at 293. 
In the next section, we will take a closer look at the major amendments of the Constitution in 1989 including the clear shift toward political leadership rather than religious leadership.

\section{Constitution Amendment}

It is ironic, and might run the risk of being an overstatement, yet the constitutional amendments of 1989 were a major step in de-Islamicization of the Islamic Republic of Iran. ${ }^{264}$ The most important amendment of the constitution pertained to the qualifications of the supreme leader position. In line with Khomeini's late ideas and in a far cry from his earlier theory of the Guardianship of a Jurist, ${ }^{265}{ }^{266}$ the supreme leader position became predominately a political post not a religious one. This development came as a result of Khomeini's shift on the "Islamicity" of the regime to "interests of Islam and country". ${ }^{267}$ This shift by Khomeini was also a move to flex his muscles towards the conservativetraditionalists who believed in Islam being the ultimate arbiter not the Valyeh Faghih

264 However, the name of the parliament was changed from National Assembly to Islamic Consultative Assembly in the amendments.

265 "The participants in the May 1989 debate on constitutional amendments had at their disposal a decade of statements, speeches, and fatwas (religious edicts), by Imam himself. Having articulated contending visions of authority, each side could draw on this rhetorical reservoir to make a case for or against a particular amendment. The institutionalists skillfully mined Khomeini's utilitarian legacy to justify the controversial proposal to separate the position of marja' from that of faquih." BRUMBERG, supra note 253, at 144.

266 The change had the strong support of Khomeini: "I...from the very beginning...insisted that the conditition of the marja'yyat was not necessary...a just mujtahed who is confirmed by the honorable experts... will be sufficient.", BRUMBERG, supra note 253, at 148.

267 "On the contrary, Khomeini played a direct role in the overall process of revisiting the Constitution. He not only issued instructions for amending critical articles such as Article 109 ..., but justified these and other changes by invoking the concept of Maslahat, or expedient interests." BRUMBERG, supra note 253, at 145. 
(supreme leader). However, in the amendment process conservatives favored the removal of the pre-requisite of Marjayiat (source of emulation) for the supreme leader position. It was because they finally saw the possibility that a person from their camp, Khamenei, had a chance of becoming the next supreme leader. Also, the Revision Council removed the basis of the supreme leader position on the popular-charismatic ground by amending Articles 5, 107, 109. ${ }^{268}$ The election of the leader became a task by an assembly of experts elected by the people. However, the authority given to the supreme leader position became even more expansive, for instance the appointment of the head of judiciary, head of the radio and TV organization, responsibility for coordinating the relations among three branches of government and setting the general policies of the regime. ${ }^{269}$ It should be noted that the scope of authority of the Assembly of Experts was also expanded. The amendment bestowed a wider supervisory discretion for the Assembly of experts allowing them to also check the political capacity of the leader. Based on the Constitution, the Assembly has the authority to dismiss the leader if he lacks any of the qualifications mentioned in the Constitution. In practice, however, this Assembly never became powerful and has remained under the control of the supreme leader. In short, the amendments were not a shift towards republicanism either. In fact it further empowered the supreme leader position in Iran vis-à-vis other institutions. Yet,

268 BRUMBERG, supra note 253, at 147. ("The original version of Article 5, it will be recalled, stipulated that the "leadership" was to "devolve upon the just and pious faqih," who was "recognized and accepted as leader by majority of the people." The latter provision celebrated Khomeini's charismatic link to the people. However, the new version of Article 5 dropped all references to any popular acclamation of the Leader."

269 ARJOMAND, supra note 242, at 39. 
the efforts cemented a dualism or schism in Iranian politics between the supreme leader position and the president creating a rather unique system.

Another critical feature of the amendments to the Constitution was its centralization of powers. The prime minister post was eliminated to further strengthen the presidency. ${ }^{270}$ The Revision Council rejected the idea of having a council of leaders instead of a single leader. It was also decided that a single person would run the judiciary for 5 years with the possibility of extension with the appointment of the supreme leader. Under the old Constitution, a five-member council was in charge of the judiciary. This same shift applied to other, less important, positions. For the director of the Radio and TV Organization, it was decided that a person be in charge instead of a council and that the supreme leader appoint the head of that organization. The centralization came as a reaction to the dysfunction as well as friction between posts stipulated in the 1979 Constitution that had paralyzed the country at times. ${ }^{271}$

Another amendment pertained to the Expediency Discernment Council (Expediency Council hereafter), which was already operating. This body came into existence as a result of friction between the parliament and the Guardian Council. As we noted, the Guardian Council was comprised of the majority of conservative-traditionalists while the left camp had the majority of parliament (especially the third parliament.). This created gridlocks and tension between these two legislative bodies. By the Constitution, the

270 Article 113 declares that the presidency is the next highest official position after the supreme leader position.

271 "The weakness of the 1979 Constitution of the Islamic Republic of Iran in terms of vaguely defining the roles and responsibilities of the various centres of power in the republic had been evident at least since the political struggle in 1980-1 between President Bani-Sadr and Prime Minister Rajai and his IRP-based clerical support.”, EHTESHAMI, supra note 232, at 34-35. 
Guardian Council holds the review authority of laws passed by parliament in terms of their compatibility with Islam and the Constitution. Over the course of the years, the Guardian Council blocked more than 40 precedents of legislation voted by the Parliament. ${ }^{272}$ The House Speaker, Rafsanjani, asked for Khomeini's intervention on several occasions which mostly ended with implicit support for the parliament initiatives. This friction eventuated in creating an extra-constitutional body by the decree of Khomeini, which was supposed to act as an arbiter between the parliament and the Guardian Council. This body, the Expediency Council, operated for more than two years and in the amendments of 1989 it finally entered the Constitution. ${ }^{273}$ Article 112 lays out the arbitral function of the Expediency Council in the new Constitution. Additionally, Clauses 1 and 8 of the Article stipulate further (yet vague) responsibilities for the Council. Clause 1 declares that the supreme leader designate the general policies after consultation with the Expediency Council. Clause 8 delegates the task of resolving conflicts to the supreme leader through the Expediency Council in case tensions cannot be resolved in other ways.

Adding an eternal clause was another noteworthy development in the constitution amendments. In the last Article (177), certain aspects of the political order of the Islamic Republic of Iran were declared unalterable through any amendment procedure of the

272 EHTESHAMI, supra note 232, at 35.

273 At times, the Council entered into lawmaking as well, a matter that instigated a letter to Khomeini by members of parliament objecting to this practice. He responded emphasizing that the Council could enter matters only if there is a difference between the parliament and the Guardian Council. Ayatollah Montazer, another major theorist of Guardianship of a Jurist, opposed the very existence of such a council: "[it] is an institute contrary to the Constitution which was set up owing to the existing necessities and the war...in the future all affairs will be managed in accordance with the constitution.", Id. 
Constitution: content of principles related to the Islamic nature of the system, the Islamic basis of all laws and regulations and faith-based principles and objectives of the political order, the republican nature of the system, guardianship of a jurist, ${ }^{274}$ the administration of countries' affairs based on popular vote and the official religion (twelfth Imam Shiiam).

The politics involved in the amendment process are critical in understanding the amended Constitution as well as the rise of Rafsanjani-Khamenei in the new political order of Iran. In the deliberations, one heated discussion was related to the post of prime minister. The right, not having the majority in the parliament, argued for the removal of the prime minister position. Furthermore, the leftist policies of Mousavi's Government during the war further instigated their opposition to the necessity of the prime minister position. ${ }^{275}$ In short, this debate was centered on presidential versus parliamentary government. Members of the Review Council surveyed several other constitutions in the world, including, ironically, the United States. ${ }^{276}$ There were also disagreements on the scope of the supreme leader's authority. The left was worried that bestowing too much power in the hands of one person would create a tyranny. The right, however, reiterated the need for the country to have a person who has the final word. They also pushed for the word "motlagh" (absolute) as the determination of the scope of the authority of the leader.

274 Interestingly enough, the exact term "velayate faghih" as used by Khomeini is not included in this Article. Instead a similar but rather vague notion is used.

275 "....in terms of the distribution of executive power in the republic the failures of the successive Mousavi government to solve Iran's economic difficulties (thanks partly to the Guardian Council's opposition to the radical legislation proposed by Mousavi and supported by the Majlis) provided further ammunition for those who advocated the abolition of the premiership.", EHTESHAMI, supra note 232, at 37.

276 BRUMBERG, supra note 253, at 145. 
They wanted to make sure the leader has the absolute power in the system without any restrictions. ${ }^{277}$ They succeeded. However, those who believed in the presidential system probably acquiesced because they calculated that the supreme leader position and the president would balance each other's authorities.

Rafsanjani, the House Speaker at the time and a close aid to the Supreme Leader, seemed to have a different agenda. His political positions and ideas did not squarely match either of the prevailing camps at the time. He can aptly be categorized as the pragmatic figure of the revolution as he always has tried to remain allies with both sides of the political spectrum. At the time of the succession, he was active and anxious to make the transition smooth and to his favor. ${ }^{278} \mathrm{He}$ vociferously endorsed a very strong presidential system ${ }^{279}$ while he pushed for a council of leaders instead of a single leader. ${ }^{280} \mathrm{He}$ was successful in advancing his agenda on having a strong president but did not have any success in his latter initiative, which was the elimination of a single supreme leader position. He, then, put all his efforts into persuading others regarding the leadership of Khamenei. In his calculation, Khamenei would never become the second Khomeini both in terms of his political power and its religious stature. He was also sure that he could win the

277 MOSLEM, supra note 237, at 84.

278 For the detail account of the days of Khomeini's passing see MoIN, supra note 248 at 299-313.

279 "according to Rafsanjani, "We cannot choose a qualified executive but strip him of the necessary powers. The current condition of the country calls for a strong executive branch." He rebuffed the dictatorship thesis of the left by pointing out, "Our country is not like the US; we have a leader who would prevent such a dictatorship. Do not be afraid of a strong president. The likes of BaniSadr no longer exist in the country.", MosLEM, supra note 237, at 86.

280 "Indeed Rafsanjani's determination to create an independent executive was such that he had initially proposed permanently replacing the position of faqih with a "Leadership Council.", BRUMBERG, supra note 253, at 146. 
presidential race and become the first powerful president of Iran without power-sharing limitations coming from the prime minister position.

Rafsanjani's plan for the succession period worked. In a surprisingly smooth transition, Khamenei was elected as the next leader of the Islamic Republic of Iran. When the Assembly of Experts was discussing the candidacy of Khamenei, Rafsanjani famously told a story from Imam: “...we said to the Imam, if the need arose for a successor to you we would have difficulties, because with the present constitution we could have a leadership vacuum. He said that this would be the case since we had the right people. When we asked who, he pointed to Mr. Khamenei." 281 This story, which some find to be concocted, was influential in the appointment of Khamenei.

The Assembly appointed Khamenei as the next leader of the Islamic Republic of Iran. The revisions of the Constitution, that had not yet been put to vote, were the guidelines for the Assembly of Experts appointing the next leader. In other words, the appointment was based on the qualifications discussed in the Revision Council. The new Constitution was put on the ballot along with the presidential election. People approved the new Constitution and Rafsanjani became the president. For the 8 years of his presidency, Rafsanjani remained powerful. However, through time the supreme leader gained power until he became undoubtedly the most powerful person in Iranian politics. 


\section{Asymmetrical Constitution}

The Iranian Constitution, unlike what is generally believed, is not a homogenous instrument. One could trace the various political thoughts paradigm in its texts. The French draft (along with the Tehran draft) created the framework of the constitution. In other words the structure of the constitution was designed during the stage of Paris and Tehran draft constitutions. The liberal ideas of the Constitution at this stage are noticeable in section three of the Constitution, which discusses the people's rights. In the Transition Government, a few leftist ideas were added to the text, which is traceable in the property ownership part of today's Constitution. Finally, Islamic ideas came in the last stage, which culminated in Ayatollah Montazeri's successful inclusion of the Velayat Faghigh Principle (Guardianship of an Islamic Jurist) in the text of the Constitution. A close analysis of the politics of Iran in juxtaposition with the development of its constitutional shows us that Iran has vestiges of constitutionalism. This is critical in understanding domestic politics as well as foreign policies of Iran.

As discussed above, the constitution of Iran ultimately morphed into a major dichotomy: a supreme leader position which oversees and, to a certain extent, controls several critical institutions such as the military, judiciary, and national television and radio; and the presidency position which is directly elected by the people and runs the governmental agencies and, to a certain extent, foreign policy. The constitutionalism in Iran, in fact was reduced to these two institutions due to the fact that in the process of institutionalizing of the constitution, the judiciary did not establish itself as an arbiter for constitutional issues. In the United States legal system, for example, the well-known case Marbury v. 
Madison established what has become the robust judicial review of constitutional matters. ${ }^{282}$ This process did not occur in Iran, partly due to the fact that the drafters of the constitution modeled the Council of Guardians after the Conseil Constitutionnel [Constitutional Council], a body to review proposed statutes by the parliament a priori, prior to their signing into law by the president. ${ }^{283} \mathrm{~A}$ few prominent legal scholars tried to create a doctrine of constitutional review but it never became a systemic constitutional review by the courts. ${ }^{284}$ As a result, in the aftermath of the "charisma era", the friction between these two institutions, (the supreme leader and president) constituted what can be called constitutionalism in Iran. The supreme leader selects the 6 Islamic jurists to be members of the Council of Guardian (responsible for constitutional review of the legislation) according to Article 91 of the constitution. ${ }^{285}$ The president, on the other

282 PAUL W. KaHn, The REIGN OF LAW: MARBURY V. MADISON AND the CONSTITUTION OF AMERICA 4-5 (1997) ("Marbury [case] shows us law's role as a contingent political possibility. Law's rule is law's victory over competing understanding of politics. These competing understandings have not disappeared; they are never completely vanished. The rule of law is a way of managing conflict of political perceptions.")

283 The Counsel was established by the Constitution of the Fifth Republic (4 October 1958) which aimed to expand the presidential power and to end the supremacy of the legislative branch that have dominated the constitutional practice of France since 1870, EDWARD MCWHINNEY, SUPREME COURTS AND Judicial LAW-Making: Constitutional TRibunals and Constitutional REview 20 (1986). According to Article 58, the Council also supervises the election of the President of the Republic to control the integrity and regularity of the election. The Council's review are either compulsory or options. It is optional where a proposed statute (or an international agreement) is referred by a political authority or a certain number of members of legislative bodies. It is mandatory, however, for institutional acts and the rules of procedure of the parliamentary assemblies, $I d$. at 19-20.

284 These scholars argued that constitution takes precedence over 'ordinary' laws of parliament and therefore a judge can apply the constitution over other laws if the rules are in conflict. Nasser Katoozian.

285 "Article 91 (Council of Guardians): With a view to safeguard the Islamic ordinances and the Constitution, in order to examine the compatibility of the legislation passed by the Islamic Consultative Assembly with Islam, a council to be known as the Guardian Council is to be constituted with the following composition: 1 . six religious men, conscious of the present needs and the issues of the day, to be selected by the Leader, and 2. six jurists, specializing in different 
hand, is responsible for "implementing the constitution and acting as the head of the executive, except in matters directly concerned with the leader" pursuant to Article 113 of the constitution. ${ }^{286}$ Therefore, the checks and balances, required under constitutionalism, have been loosely achieved through this friction. In other words, the constitution of Iran remain an incomplete (or unfinished) document-similar to many other if not all constitutions - waiting to be completed. And, these two institutions are the only ones capable of shaping the constitutionalism in Iran.

\section{International Agreements as a Balancing Factor}

Iran has a long history of engagement with international law: from the Anglo-Iranian Oil case in 1952 which paved the way for nationalization of oil to the Joint Comprehensive Plan of Action (JCPOA) in 2015 whereby Iran reached an agreement with 6 countries concerning its controversial nuclear program. Iran also complied with international law on several occasions, most notably the recent dismantling of its nuclear centrifuges as stipulated under the JCPOA. ${ }^{287}$

areas of law, to be elected by the Islamic Consultative Assembly from among the Muslim jurists nominated by the Head of the Judicial Power."

286 "Article 113 (President): After the office of Leadership, the President is the highest official in the country. His is the responsibility for implementing the Constitution and acting as the head of the executive, except in matters directly concerned with the office of the Leadership."

287 See e.g. Kelsey Davenport, Iran Dismantling Centrifuges IAEA Says, ARMS CONTROL ASSOCIATION, December 2015, available at https://www.armscontrol.org/ACT/2015 12/News/Iran-Dismantling-Centrifuges-IAEA-Says 
One of the most important defining factors in Iranian politics was foreign policy and engagement with other countries. This became ever more important in the postestablishment period given that Iran experienced a long war and was determined to break from the isolation it experienced due to war and its foreign policy.

In addition to foreign policy objectives, much less discussed, is the effect of engagement with international law in elevating the presidency vis-à-vis the supreme leader's position. In other words, the presidency under the constitution suffered from what we can call 'deficiency' in the authorities vested to its position especially vis-à-vis the supreme leader position. Under the constitution, the supreme leader enjoys the hard power, inter alia, by being the commander-in-chief of the military forces. On the other hand, the presidency does have direct control over the military forces and as a result should resort to soft power in order to balance the powers under the constitution. One of the most important avenues of soft power in possession of the presidents has evolved to be their engagement with international law.

\section{Algerian Accords}

In the aftermath of the Revolution, a group of Iranians belonging to what was called Muslim Student Followers of the Imam's Line, took over the U.S. embassy in Tehran and held hostage fifty-two Americans for 444 days from November 4, 1979 to January 20, 1981. ${ }^{288}$ This created a tremendous political backlash in the United States where it was 
felt that the United States could not protect its own people. ${ }^{289}$ After a political battle between the United States and Iran, the hostages were released and both countries entered into a set of international agreements known as Algiers Accords on January 19, 1981. In the aftermath of the hostage-taking, President Carter issued Executive Order 12170 on November 14, 1979 in which he declared that he found "the situation in Iran constitutes an unusual and extraordinary threat to the national security, foreign policy and economy of the United States and hereby declare a national emergency to deal with that threat." 290 This state of emergency — which also resulted in the blockage of the Iranian government assets—-was never reversed. ${ }^{291}$

The Algiers Accords are the first pivotal international agreement Iran entered into to resolve a crisis. The Accords, which was designed to settle the crisis, contained a set of agreements consisting of the General Declaration and the associated Undertakings of the United States and Iran, and the Claims Settlement Declaration. ${ }^{292}$ The Accords

289 David Farber, TAKEn Hostage the IRAn Hostage and America's First EnCOUNTER With RADICAL ISLAM 1-2 (2005). The hostage crisis ended right when Carter yielded the presidency to Reagan. It was a very emotional moment for Americans when the hostages were freed in Algiers. Warren M. Christopher who helped negotiate the settlement with the Iranian government stated that it was a moving occasion for everyone when the hostages were released: "There were very few people with dry eyes, and I was not among them,"Bart Barnes, Former Secretary of State Warren Christopher, Who Negotiated Settlement to Iran Hostage Crisis, Dies at 85, THE WASHINGTON POST, March 19, 2011, available at: https://www.washingtonpost.com/local/obituaries/former-secretary-of-state-warren-christopherdies-at-85/2010/09/21/ABCPk6t_story.html?utm_term=.8c1de9b1579c

290 3 C.F.R. § 1979.457 Comp. (1979)

291 Even after the agreement reached between the United States and Iran in July of 2015, Barack Obama extended the 'emergency' status because the US-Iran relationship "have not yet returned to normal, and the process of implementing the agreements with Iran, dated January 19, 2011, is still underway." Obama Renews National Emergency on Iran, TeHran Times, January 14, 2017, available at http://www.tehrantimes.com/news/410050/Obama-renews-national-emergency-on$\underline{\text { Iran. }}$

292 John G. Collier and Vaughan Lowe, The Settlement of Disputes in International LaW: INSTITUTIONS AND PROCEDURES 75 (2000). 
established, among others, that the United States would not politically and militarily intervene in internal affairs of Iran and the United States, and that certain frozen assets of Iranian government would be transferred back to Iran. ${ }^{293}$ The Accords also established an unprecedented dispute resolution mechanism; a mechanism that, by some accounts, is a grandfather of many of the later transnational dispute resolution mechanisms: "An International Arbitral Tribunal (the Iran-United States Claims Tribunal) is hereby established for the purpose of deciding claims of nationals of the United States against Iran and claims of nationals of Iran against the United States."294

The Algiers Accords resolved Iran's first major foreign policy crisis. It also legalized the new normal between Iran and the United States: an emergency status where dispute resolution mechanism is designed to settle legal and commercial disputes without the need for political espousal. Further, Algiers Accords was reached when a domestic compromise was needed since Bani Sadr, the president, was against the hostage crisis and wanted the matter to be handled by the president office. Khomeini rejected this request and asked the parliament to make a decision on this matter. Ultimately, the parliament

293 Algiers Accords, 20 ILM 223 (1981); In spite of the commitment of the U.S. to unfreeze certain properties, on March 26, 1981, a few months after the execution of the Algiers Accord, the United States did not approve licenses of the export of Iranian military equipment located in the United States invoking the restrictions imposed by Arms Export Control Act and its implementing regulations. Iran filed a $\$ 2.5$ billion claim for the items to be returned, or in the alternative, the value of such items. The Iran-U.S. Claims Tribunal on July 17, 2009, in a case known as Case B/61 rejected this claim, U.S. DePartment of State, Digest of United States Practice in INTERNATIONAL LAW, Chapter 8, available at https://www.state.gov/documents/organization/153979.pdf

294 Article II of Declaration of the Government of the Democratic and Popular Republic of Algeria Concerning the Settlement of Claims by the Government of the United States of America and the Government of the Islamic Republic of Iran, 20 ILM 223 (1981). 
appointed, Behzad Navai, to lead the negotiations for the settlement of the Hostage Crisis. ${ }^{295}$

The Tribunal was established pursuant to the Algiers Accords. The agreement was predicated on the release of the hostages who were held in Iran for 444 days. The United States, in return, agreed to return Iranian assets and withdraw from the prosecution of Iran in international courts on this matter. Following the agreement, the hostages were released and $\$ 8.1$ billion was transferred to an escrow account. Out of $\$ 2$ billion of unfrozen Iranian assets, $\$ 1$ billion were also kept in a security account from which sums awarded to US nationals by the Tribunal could be collected. ${ }^{296}$ The main document establishing the Tribunal is the Claim Settlement Declaration. Article II sets the scope of the Tribunal:

"1. An international arbitral tribunal (the Iran-United States Claims Tribunal) is hereby established for the purpose of deciding claims of nationals of the United States against Iran and claims of nationals of Iran against the United States, and any counterclaim which arises out of the same contract, transaction or occurrence that constitutes the subject matter of that national's claim, if such claims and counterclaims are outstanding on the date of this Agreement, whether or not filed with any court, and arise out of debts,

295 Bayram Sinkaya, The ReVolutinary Gaurds in IRANian Politics: Elites AND ShifTing 88 (2016). This was also a compromise for divergent foreign policy views: "Contrary to radicals, Banisadr, and his foreign minister, Safegh Qotbzadeh, defended maintenance of the nonalignment and equidistance policy of the Provisional Government. Moderates led by Banisadr adopted 'Iran first' policy and were uncomfortable with the radicals' relations with the liberation movements abroad.", Id.

296 Charles N. Brower \& Jason D. Brueschke, The IRAn-United States Claims Tribunal 7-10 (1998). 
contracts (including transactions which are the subject of letters of credit or bank guarantees), expropriations or other measures affecting property rights...

2. The Tribunal shall also have jurisdiction over official claims of the United States and Iran against each other arising out of contractual arrangements between them for the purchase and sale of goods and services...

3.The Tribunal shall have jurisdiction, as specified in Paragraphs 16-17 of the Declaration of the Government of Algeria of January 19, 1981, over any dispute as to the interpretation or performance of any provision of that Declaration." 297

The scope of the jurisdiction of the Tribunal is rather broad. It includes sales of goods and services, agency relationships, export and import, expropriation and state responsibility, corporation-related matters and many more.

Through the establishment of Iran-US Claim Tribunal by the Algiers Accords, Iran entered into a regular judicial contact with the United States. The body has been responsible to handle commercial claims of the U.S nationals against Iran and of Iranian nationals against the United States, which arise out of contracts, debts, expropriation, and other measures affecting the property right of individuals. Approximately 3800 claims were filed before the deadline stipulated, which was a year from the date of execution of the Algiers Accords. ${ }^{298}$

297. Iran-United States Claims Settlement Declaration, IRAN-UnITED STATES ClaIMS TRIBUNAL, http://www.iusct.net/General\%20Documents/2-Claims\%20Settlement\%20Declaration.pdf.

298 Official Website of the Iran-US Claims Tribunal, https://www.iusct.net/Pages/Public/AAbout.aspx 


\section{Oil Platform Case}

Towards the end of the Iran-Iraq war a series of incidents occurred that created another source of tension between Iran and the United States. The main attacks involved destruction of two Iranian oil platforms in what the Reagan administration announced was retaliation for the mining that damaged a U.S. navy vessel a week prior to that. In the incident, at the order of Reagan, six American ships destroyed two Iranian oil platforms which led to severe casualties. Iran announced that the two platforms produced 150,000 barrels per day. ${ }^{299}$

The attacks on the oil platform were the culmination of a series of clashes between Iran and the United States in the Persian Gulf. These tensions were partly due to the change of Reagan's policy to take a more active role in the Persian Gulf and Iran-Iraq war. ${ }^{300}$ Iran at the time decided not to escalate the situation. As a result of these confrontations, Khomeini appointed Rafansani, who was a speaker of the parliament at the time, as the acting commander in chief for the forces. Rafsanajni was a known to be a pragmatic figure in Iranian politics and this move would de-escalate the situation. ${ }^{301}$ Further, Iran decided to pursue this claim before an international court. The case was ultimately filed before the International Court of Justice in $1992 .{ }^{302}$ In this case, Iran invoked the Treaty

299 John Cushman, U.S. Strikes 2 Iranian Oil Rigs and Hits 6 Warships in Battles over Mining Sea Lanes in Gulf, N.Y. TIMES, April 19, 1988.

300 History of Maritime Clashes between Iran and United States, BBC PERSIAN, August 26, 2016. (in Farsi), $\quad$ available http://www.bbc.com/persian/iran/2016/01/151231 145 iran us military confrontation

301 SinKAYA, supra note 295 at 122-123.

302 Case Concerning Oil Platforms (Iran v. US), 1996 I.C.J. 803 (12 December) II1. 
of Amity, Economic Relations and Consular Rights between Iran and the United States signed before the revolution to establish jurisdiction of the court. The treaty that was never officially revoked by the parties, established jurisdiction for International Court of Justice in Article XXI: "Any dispute between the High Contracting Parties as to the interpretation or application of the present Treaty, not satisfactorily adjusted by diplomacy, shall be submitted to the International Court of Justice, unless the High Contracting Parties agree to settlement by some other pacific means." 303

The United States first invoked the treaty in the case it brought before the International Court of Justice in connection with the hostage crisis. The court in the case found that:

"The very purpose of a treaty of amity, and indeed of a treaty of establishment, is to promote friendly relations between the two counties concerned, and between their two peoples, more especially by mutual undertakings to ensure the protection and security of their nationals in each other's territory. It is precisely when difficulties arise that the treaty assumes its greatest importance, and the whole object of Article XXI, paragraph 2, of the 1955 Treaty was to establish the means for arriving at a friendly settlement of such difficulties by the Court or by other peaceful means." 304

Iran and the United States reversed their positions on the validity and applicability of this treaty in the oil platform case. In this case, Iran argued that the court had jurisdiction pursuant to the 1955 Treaty. The United States, however, argued that the treaty and its

303 Treaty of Amity, Economic Relations and Consular Rights, U.S.-Iran, Aug. 15, 1955, 284 U.N.T.S. 110.

304 Case Concerning United States Diplomatic and Consular Staff in Tehran (Iran v. US), 1980 I.C.J 3. (May 24) at 9154. 
reference to commerce would not include situations such as the attacks on the oil platforms. The court upheld jurisdiction and ultimately ruled that the treaty would encompass the situation before it as the word 'commerce' in the treaty cannot be only restricted to 'maritime commerce' as argued by United States. ${ }^{305}$ The court had to decide, inter alia, whether destruction of the platforms could violate 'freedom of commerce' and whether commerce' was to be considered as 'maritime commerce.' 306

\section{Investment Laws}

The Iranian Constitution has serious limits on direct foreign investment. Article 81 of the Constitution, which concerns foreign business stipulates: "Granting of concessions to foreigners for the incorporation of companies or institutions dealing with commerce, industry, agriculture, service, or mineral extraction, is absolutely forbidden." ${ }^{307}$ The broad language of the Article is quite discouraging for foreign companies hoping to invest in Iran. Foreign companies have to establish subsidiaries in Iran because they cannot be the majority shareholders. The Council of Guardians, which is the interpretive authority of the Iranian Constitution, ${ }^{308}$ specifies that in private sectors foreign companies can own up to $49 \%$ of companies' shares. Furthermore, companies that are

305 Case Concerning Oil Platforms (Iran v. US), 1996 I.C.J. 803 (12 December) I[41.

306 Rosalyn Higgins, Natural Resources in the Case Law of the International Court, in International Law and Sustainable Development 87, 101 (eds., Alan Boyle \& David Freestone, 1999).

307 Qanuni Assassi Jumhuri Islamai Iran [The Constitution of the Islamic Republic of Iran] 1358 [1980], art. 81.

$308 \quad I d$ art. 98. 
involved in commerce with the Iranian Government can be incorporated in Iran for the purpose of their legal and operational activities. ${ }^{309}$ Another major obstacle in the Constitution concerning foreign investment is Article 44. This article defines the scope of the state sector, which should be publicly owned. In practice, the expansive and wide scope of this Article places many important sectors of the economy in the hands of the Government. Article 44 paragraph II states:

"The state sector is to include all large-scale and mother industries, foreign trade, major minerals, banking, insurance, power generation, dams, and large-scale irrigation networks, radio and television, post, telegraph and telephone services, aviation, shipping, roads, railroads and the like; all these will be publicly owned and administered by the State. $" 310$

Article 44 of the Iranian Constitution poses yet another critical challenge for the Iranian Government in the area of foreign investment. The Government has desired to transfer its less lucrative businesses to the private sector so that better management would revive the businesses. For this reason, starting in 2005 under the supervision of the Expediency Council, the Iranian Government started to gradually transfer its businesses, including banking and communications, to the private sector. ${ }^{311}$

309 The interpretation of the Council of Guardians regarding Article 81 of the Constitution can be found at their official website: http://www.shora-gc.ir/Portal/Home/ ShowPage.aspx? Object=News\&ID=75c294c8-9fe5-4d8f-89a1-f77f7b1333c7\&LayoutID=

310 Qanuni Assassi Jumhuri Islamai Iran [The Constitution of the Islamic Republic of Iran] 1358 [1980], art. 44.

311 The Supreme Leader of Iran announced a new interpretation of Article 44 of the Constitution in order to initiate a strong momentum for privatization, EVALEILA PESARAN, IRAN'S STRUGGLE FOR ECONOMIC INDEPENDENCE: REFORM AND COUNTER-REFORM IN THE POST-REVOLUTIONARY ERA 136 (2011). 
Lastly, it is Article 139 of the Constitution, which is related to arbitration, also affects foreign investment. Foreign investors, in general, are skeptical and reluctant to refer their disputes to Iranian domestic courts and tend to prefer arbitration. Article 139 of the Iranian Constitution, however, is a major obstacle in this regard:

"The settlement of claims relating to public and state property or the referral thereof to arbitration is in every case contingent on the approval of the Board of Ministers, and the Parliament must be informed of these matters. In cases where one party to the dispute is a foreigner, as well as in important domestic cases, the approval of the Parliament must also be obtained. Law will specify the cases which are considered to be important." 312

There are other domestic provisions that are not friendly to foreign investment. For instance, labor law in Iran, generally speaking, makes it difficult for employers to lay-off employees. ${ }^{313}$ Furthermore, originally the tax imposed on corporations was $54 \%$, and it has been reduced to $25 \% .{ }^{314}$ Still, this might be high taxation for corporations, which can choose to operate in countries with much lower income tax rates.

There are other obstacles in Iranian domestic law which makes foreign investment difficult. Ownership of real property by foreign nationals requires a special process. ${ }^{315}$ First, the local Registry Office should be adequately informed about the purchase. The

312 Qanuni Assassi Jumhuri Islamai Iran [The Constitution of the Islamic Republic of Iran] 1358 [1980], art. 139

313 See, e.g., Art 21-33 of Iran Labor Law available at Princeton Iran Data Portal: http://www.princeton.edu/irandataportal/laws/labor-law/laborcontracts/.

314. Iran: Company Laws and Regulations Handbook, Volume 1: Strategic Information and Basic Law 157-160 (International Business Publications ed. 2012).

315 Iran Export, Investment Climates: Status of Foreign Nationals, (last visited Mar. 3, 2014), http://www.iran-export.ir/sections/investmentclimates/statusof.aspx. 
transfer of ownership is then subject to approval by the office of Ministry of Foreign affairs on the condition of the principle of reciprocity. ${ }^{316}$

Following an eight-year war with Iraq, Iran decided to attract foreign investment in order to rebuild and reconstruct its economy and infrastructure. This dire need coincided with a surge of political strength from reformists that culminated in the election of a reformist president in 1997. In a period of expansion in foreign investment from 1995 to 2007, Iran drafted approximately 50 bilateral investment treaties (BIT) with both developed and developing countries. Through this, Iran signaled its determination to attract foreign investment to developed countries. In addition, Iran hoped to prevent and undermine the effects of international sanctions with the help of its bilateral treaties with various countries.

Bilateral Investment Treaties (BITs) are gaining increasing importance in international law. BITs are, as some scholars believe, the product of fear of developed countries of nationalization and expropriation. ${ }^{317}$ Iran performed one of the earliest and significant nationalization processes in $1951 .^{318}$ The United Nations General Assembly also recognized this nationalization of rights of developing states. ${ }^{319}$ This further complicated

316. Id.

317. Kenneth J. Vandevelde, A Brief History of International Investment Agreement, 12 U.C. DAVIS J. INTL' L. \& POLICY 157, 167-169 (2005-2006).

318. In a battle with Anglo-Iran Oil Company (AIOC), Mossadegh, Iran's prime minister, announced that Iran would sell oil directly to customers. See Mostafa ElM, Oil, POWER, AND PRINCIPLE: IRAN's OIL NATIONALIZATION AND ITS AFTERMATH 144 (1991). It was followed by the passage of Iran's nationalization act in Parliament and the evacuation of Brits and employees of AIOC from oil-rich area of Abadan, Iran. See id. at 156-60.

319. Declaration on the Establishment of a New International Economic Order, G.A. Res. 3201 (SVI),,II 4(e), U.N. Doc. A/RES/S-6/3201 (May 1, 1974) "Full permanent sovereignty of every State over its natural resources and all economic activities. In order to safeguard these resources, 
the scene for developed countries. This caused developed countries to search for and find alternative ways to protect their investment and obtain proper compensation such as in cases of expropriation. The first BIT dates back to 1959 between West Germany and Pakistan and since then approximately 2600 BITs have been concluded between different countries..$^{320}$

Iran has been the subject of foreign investment for almost one hundred years. The past investment agreements have created cynicism towards foreign investment among Iranians. The Constitution of the Islamic Republic of Iran clearly shows the overall skepticism regarding foreign investment. One of the main concerns dealt with providing concessions to foreign companies for an extended period of time as happened in the case of the Anglo-Persian Oil Company.

\section{Iran Nuclear Deal and Its Legalistic Nature}

Iran's approach in its negotiations for the Iran nuclear deal was quite legalistic in nature. Iran relied heavily on international law. It was Iran that suggested the Iran deal be incorporated as a U.N. Resolution to give the deal legal force. From 2014 onwards, Iran team benefitted from legal opinions of Mr. Jamshid Momtaz, a towering figure in international law. Mr. Momtaz authored more than thirty books and academic articles and

each State is entitled to exercise effective control over them and their exploitation with means suitable to its own situation, including the right to nationalization or transfer of ownership to its nationals, this right being an expression of the full permanent sovereignty of the State. No State may be subjected to economic, political or any other type of coercion to prevent the free and full exercise of this inalienable right". Id.

320. Kenneth J. Vandevelde, Bilateral Investment Treaties, 1 (Oxford University Press 2010). 
was known in the international law circle. In 2014 he opined that "[ $\mathrm{t}]$ he expectation that the P5+1 countries could decide about this matter instead of the Security Council is not logical. The Security Council is an independent institution which can adopt resolutions." ${ }^{321}$ He planted the idea that this agreement should have a legalistic nature endorsed by the U.N. Security Council. Iran's approach in the negotiation was very legalistic trying to frame the agreement under international law. Javad Zarif who was the lead negotiator on behalf of Iran also has a background in international law. From 2002 to 2007, he worked at the U.N as Iran's permanent representative to the United Nations. In one interview he said that "I should not accept negotiations which, as their foundation, have a violation [of] international law." He repeatedly stated that "Iran is committed to principles of international law." ${ }^{322}$ Moreover, even though Iran strongly rejected the U.S. invention of the "snap back" mechanism under the Iran nuclear deal, it ultimately accepted it. ${ }^{323}$ Below is an analysis of the legal nature of the Iran Nuclear Deal.

What is known as the Iran Nuclear Deal is the Joint Comprehensive Plan of Action (JCPOA), reached between the six countries (viz China, France, Germany, the Russian Federation, the United Kingdom, and the United States as well as the High Representative of the European Union for Foreign Affairs and Security Policy) and Iran regarding Iran's controversial nuclear program on July 14, 2015. The JCPOA was a result of at least 20 months of negotiations which resulted in the initial Joint Plan of Action in

321 Statements of Dr. Jamshid Momtaz, Iranian Diplomacy, 27 August 2014, available at http://www.irdiplomacy.ir/en/page/1937512/Comprehensive+Agreement+Depends+on+Lifting+of + Sanctions.html

322 Q\&A With Mohammad Javad Zarif, Iran's Foreign Minister, 15 December 2013, available at https://www.belfercenter.org/publication/qa-mohammad-javad-zarif-irans-foreign-minister

323 Trita PARSi, Losing an ENEMy: Obama, IRAN, AND the TRIUMPH OF DiPlomacy 303 (2017). 
November 2013, ${ }^{324}$ a framework deal in April 2015, ${ }^{325}$ and ultimately the JCPOA. ${ }^{326}$ The JCPOA was endorsed by the United Nation Security Counsel Resolution (UNSCR) 2231, which, inter alia, provided for termination of previous UNSCR's resolutions imposing sanctions on Iran and designated Iranian entities ${ }^{327}$ subject to "snap back" of sanctions. ${ }^{328}$ The "snap back" refers to an innovative method designed by the JCPOA which will be triggered upon disagreement on compliance with obligations set forth under the JCPOA by which "the UN Security Council, in accordance with its procedures, shall vote on a resolution to continue the sanctions lifting." ${ }^{329}$ Under this scenario, it takes only a state with a veto power (United States, most likely in this case) to prevent continuation of sanctions relief for the Iranian government, which inevitably result in restoration of the UN sanctions regime.

The nature of the JCPOA has become ever more important as President Trump is contemplating to impose tougher sanctions on Iran, ${ }^{330}$ the U.S. has signaling that he

324 Joint Plant of Action, November 24, 2013, available at http://eeas.europa.eu/archives/docs/statements/docs/2013/131124_03_en.pdf

325 Laura Rozen, Iran, P5+1 Reach 'Historic' Framework Deal, Al MONITOR, April 2, 2015, available at http://www.al-monitor.com/pulse/originals/2015/04/zarif-iran-deal-reactions-lausanne-nuclear$\underline{\text { talks.html }}$

326 Joint Comprehensive Plan of Action, July 14, 2015, available at http://www.un.org/en/ga/search/view doc.asp?symbol=S/2015/544

327 S.C. Res. 2231, II7, U.N. Doc. S/2015/544 (July 16, 2015).

328 Article 37. Joint Comprehensive Plan of Action, July 14, 2015, available at http://www.un.org/en/ga/search/view_doc.asp?symbol=S/2015/544

329 Id.

330 Dan De Luce, Trump Mulls Squeezing Iran with Tougher Sanctions, ForeIGN PoliCy BLOG, April 17, 2017 available at http://foreignpolicy.com/2017/04/17/trump-mulls-squeezing-iran-withtougher-sanctions/ 
would tear down the deal, ${ }^{331}$ and the U.S. Senate passed a 10-year extension of some existing sanctions and vowed to collaborate with the Trump administration on the increase of sanctions on Iran. ${ }^{332}$ These measures would be in direct conflict with the core of the Iran deal—which was sanctions relief in exchange for Iran's set back of its nuclear program - and are endorsed by the idea that the deal is an unsigned, non-binding agreement from which the United States can simply walk away. ${ }^{333}$

The legal status of the JCPOA - the most important nuclear agreement in the post-Cold War era and an exemplar of Obama's foreign policy doctrine-is unclear. Both domestically and internationally, scholars, politicians and pundits have reached different conclusions on the binding nature of the agreement. The fate of the JCPOA from the legal standpoint will shed light on the legal developments pertaining to international deal making in the post-Cold War era and would serve as a framework for future international agreements. Both the dynamics of international relations and the paradigms of international law have changed significantly since the Cold War era, and the JCPOA would have undeniable and irreversible international legal consequences. Even if the

331 Yeganeh Torbani, Trump Election Puts Iran Nuclear Deal on Shaky Ground, Reuters, Nov. 1, 2016, available at http://www.reuters.com/article/us-usa-election-trump-iran-idUSKBN13427E

332 Extension of Iran Sanctions Act Passes US Congress, ReuTER, December 1, 2016 available at http://www.jpost.com/Middle-East/Extension-of-Iran-Sanctions-Act-passes-US-Congress-474245; Jordain Carney, Senators to Trump: We Support Additional Iran Sanctions, THE HILL, February 2, 2017, available at http://thehill.com/blogs/floor-action/senate/317682-senators-to-trump-wesupport-additional-iran-sanctions

333 Iulia E. Padeanu, Is the Trump Administration Bound by the Iran Deal? YALE J OF INT'L L ONLINE, Dec. 1, 2016 available at http://campuspress.yale.edu/yjil/is-the-trump-administrationbound-by-the-iran-deal/ ; Simon Kriesberg et al, US Sanctions Against Iran: Outlook Under President Trump, LAW 360, Jan. 3, 2017, available at https://www.law360.com/articles/877002/us-sanctions-against-iran-outlook-under-presidenttrump; Can Trump Kill Iran Nuclear Deal Just by Walking Away? Yes, U.S. Officials, WoRLD TRIBUTE, Nov. 13, 2016, available at http://www.worldtribune.com/can-trump-kill-iran-nucleardeal-by-walking-away-yes-say-u-s-officials/ 
parties may individually claim that the resulting agreement is non-binding, international law may deal them a hand they do not expect, and force them to confront a reality that they had not contemplated. The U.S. State Department in a letter opined that the JCPOA is not a treaty and "the success of the JCPOA will depend not on whether it is legally binding." 334 Time will tell; but in fact, not only success of the JCPOA but also Obama's approach to foreign policy by deal making might be dependent on the legal nature of the JCPOA.

The Evasive Nature of the Iran Nuclear Deal

There is no consensus, however, as to whether the JCPOA is legally binding upon the parties and is devoid of legal consequences. ${ }^{335}$ At the time the agreement was taking

334 United States Department of State, Letter to Mike Pompeo, Nov. 19, 2015. Also available at http://www.nationalreview.com/article/427619/state-department-iran-deal-not-legally-bindingsigned (emphasis added)

335 See e.g. John B Bellinger, How Binding Is the Iran Deal? CounCIL ON ForeIGN RELATIONS, July 23, 2015, available at http://www.cfr.org/iran/binding-iran-deal/p36828; Colum Lynch \& John Hudson, Obama Turns to U.N. to Outmaneuver Congress, ForeIGn PoLICY, July 15, 2015, available at http://foreignpolicy.com/2015/07/15/obama-turns-to-u-n-to-outmaneuver-congressiran-nuclear-deal/; Jack Godsmith, Why Congress is Effectively Powerless to Stop the Iran Deal (and Why the Answer is Not the Iran Review Act), LaWfare, July 20, 2015, available at https://www.lawfareblog.com/why-congress-effectively-powerless-stop-iran-deal-and-whyanswer-not-iran-review-act; Bruce Ackerman \& David Golove, Can the Next President Repudiate Obama's Iran Agreement? THE ATLANTIC, September 10, 2015 available at https://www.theatlantic.com/politics/archive/2015/09/can-the-next-president-repudiate-obamasiran-agreement/404587/; Julian Ku, President Rubio/Walker/Trump/Whomever can Indeed Terminate the Iran Deal on "Day One", OPINIO JURIS, September 10, 2015 available at http://opiniojuris.org/2015/09/10/president-rubiowalkertrumpwhomever-can-indeed-terminate-theiran-deal-on-day-one/; ("Iran Deal does not bind his predecessor either as a matter of constitutional or international law.") Bruce Ackerman \& David Golove, Guest Post: The Lawless Presidency of Marco Rubio-a Reply to Professor Ku, OPINIO JURIS, Sept. 16, 2015, available at http://opiniojuris.org/2015/09/16/guest-post-the-lawless-presidency-of-marco-rubio-a-reply-toprofessor-ku/; Farshad Ghodoosi, Defining the Relationship: Terminology and the Iran Deal, 
shape, several U.S. senators, ${ }^{336}$ House lawmakers, ${ }^{337}$ and some academics ${ }^{338}$ have opined that the agreement is non-binding and fragile. These constituencies portray the deal as devoid of any binding obligations for the parties and untethered to international law anchors. ${ }^{339}$ International sanctions and commitments made pursuant to the agreement can be "snapped back" in a matter of hours, showing the fragility and non-binding nature of the agreement.

The negotiators themselves had divergent views on the nature of the JCPOA. Secretary of State Kerry believed that it would be no more than a political commitment. ${ }^{340}$ His Iranian

FOREIGN AFFAIRS, April 5, 2015, available at https://www.foreignaffairs.com/articles/unitedstates/2015-04-05/defining-relationship

336 Letter From Republican Members of the United States Senate to the Leaders of the Islamic $\begin{array}{lllll}\text { Republic of Iran 2015), } & \text { (Mar. }\end{array}$ https://s3.amazonaws.com/s3.documentcloud.org/documents/1683798/the-letter-senaterepublicans-addressed-to-the.pdf.

337 Letter from Members of the United States House of Representatives to President Barack Obama (Mar. 20 , 2015), http://foreignaffairs.house.gov/sites/republicans.foreignaffairs.house.gov/files/03.20.15\%20\%20Iran\%20Letter\%20-\%20POTUS.pdf.

338 Jack Goldsmith, How a U.N. Security Council Resolution Transforms a Non-Binding Agreement with Iran Into a Binding Obligation Under International Law (Without Any New Senatorial or Congressional Vote), LAWFARE (Mar. 12, 2015, 8:37 AM), http://www.lawfareblog.com/2015/03/how-a-u-n-security-council-resolution-transforms-a-nonbinding-agreement-with-iran-into-a-binding-obligation-under-international-law-without-any-newsenatorial-or-congressional-vote; Julian Ku, Iran Responds to US Senators' Letter, Shows Why Congress Should Be Involved in the First Place, OPINIO JURIS (Mar. 9, 2015, 10:08 AM), http://opiniojuris.org/2015/03/09/iran-responds-to-us-senators-letter-shows-why-congress-shouldbe-involved-in-the-first-place.

339 See Duncan Hollis, The Iran Deal as a Political Commitment, OPINIO JuRIs (Apr. 2, 2015, 6:00 PM), http://opiniojuris.org/2015/04/02/the-iran-deal-as-a-political-commitment; see also Duncan Hollis, Dealing with Iran: A Primer on the President's Options for a Nuclear Agreement, OPINIO JURIS (Mar. 11, 2015, 2:52 PM), http://opiniojuris.org/2015/03/11/dealing-with-iran-a-primer-onthe-presidents-options-for-a-nuclear-agreement. For the conservative characterization of the deal, see Tim Mak, GOP Goes_Ballistic Over Plan to Take the Iran Nuke Deal to the U.N., THE DAILY BEAST (Mar. 12, 2015, 9:30 PM), http://www.thedailybeast.com/articles/2015/03/12/gop-goesballistic-over-plan-to-take-the-iran-nuke-deal-to-the-u-n.html.

340 Bradley Klapper, Kerry says Congress would not be able to change terms of Iran deal, PBS NewsHOUR (Mar. 11, 2015, 1:41 PM), http://www.pbs.org/newshour/rundown/kerry-says- 
counterpart, Foreign Minister Zarif, contended that the deal would be binding under international law and that any repudiation by the US would constitute a "blatant violation." 341 Russian officials suggested that a United Nations Security Council Resolution incorporate the deal to render it secure, a position that was reflected in the Joint Statement as well and was ultimately implemented. ${ }^{342}$

The JCPOA between Iran and the P5+1 countries is the most important nuclear disarmament deal since the end of the Cold War, an accomplishment that would be especially significant because the parties negotiated against the backdrop of a complex web of sanctions stemming from three sources: the U.N. Security Council, the United States, and the European Union. Despite its importance, there is a cloud of uncertainty as to the nature of the agreement: whether the agreement creates legal obligations under international law and whether parties can breach the agreement without violating international law. This piece will first examine the parties' divergent views of political commitments under international law, and then will enumerate the notable changes to international law since the end of the Cold War.

\section{A Souvenir from the Cold War: Political Agreements}

congress-able-change-terms-iran-deal ('We've been clear from the beginning: We're not negotiating a, quote, legally binding plan ....”).

341 Eline Gordts, Iran's Foreign Minister To U.S. Senators: 'The World Is Not the United States', HuFFINGTON POST (Mar. 9, 2015, 5:34 PM), http://www.huffingtonpost.com/2015/03/09/zarifsenators-letter_n_6834296.html. Zarif tweeted his opinion on this matter in response to the 47 senators' letter warning Iran that "the next president could revoke such an executive agreement with the stroke of a pen ...." Republican Senators, supra note 336.

342 Iran Nuclear Deal Can Be Secured by UN Security Council Resolution-Russian Diplomat, APA (Apr. 16, 2015, $\quad 1: 45 \quad$ AM), http://en.apa.az/xeber_iran_nuclear_deal_can_be secured by un_s_225842.html; Compare with Bellinger, supra note 335 ("the UN resolution does not bind the United States to lift sanctions.") 
The 1975 signing of the Final Act of the Helsinski Conference gave rise to the current debate over non-binding international agreements. ${ }^{343}$ Despite the great importance and substantial length of that agreement, the signatories made it abundantly clear that they did not intend it to be a binding treaty. ${ }^{344}$ Writing afterwards, Oscar Schachter argued that non-binding international agreements "can [still] be authoritative and controlling for the parties," 345 and that it is wrong to believe that these "undertakings are illusory because they are not legal." 346

The issue remains unsettled; some scholars contend that every commitment made by states is inevitably legal, ${ }^{347}$ and that states cannot shield their agreements from the international legal regime. The International Court of Justice's holding in Qatar $v$. Bahrain serves as a good example of that theory: the Court held that the shared minutes of a negotiation between Qatar, Bahrain, and Saudi Arabia constituted a legally binding agreement under international law. ${ }^{348}$ Following the decision, a noted commentator opined that the holding "struck the final death blow to [the idea that] ... states c[ould]

343 Final Act of the Conference on Security and Cooperation in Europe, 14 ILM 1292 (1975).

344 "The Government of the Republic of Finland is requested to transmit to the Secretary- General of the United Nations the text of this Final Act, which is not eligible for registration under Article 102 of the Charter of the United Nations, with a view to its circulation to all the members of the Organization as an official document of the United Nations." Id. at 1325.

345 Oscar Schachter, The Twilight Existence of Nonbinding International Agreements, 71 AM. J. INT'L L. 296, 304 (1977).

346 Id. at 303 (1977).

347 JAN KLABBERS, THE CONCEPT OF TREATY IN INTERNATIONAL LAW 163-64 (1996).

348 Maritime Delimitation and Territorial Questions Between Qatar and Bahrain (Qatar v. Bahrain), 1994 I.C.J. 112, III 31-39 (July 1) (Jurisdiction and Admissibility). 
conclude agreements outside of legal order." 349 This approach is re-enforced by the notion that under international law, even unilateral statements by states can produce binding obligations if it is clear with specific terms. ${ }^{350}$

Some scholars have distinguished between the binding nature of international agreements signed between states and the legal consequences arising from such agreements. Anthony Aust, then serving as legal counselor of UK's Foreign and Commonwealth Office, wrote in 1986 that "[ $\mathrm{t}]$ here can be little doubt that the vast majority of informal instruments do record agreements (using the term in its ordinary sense) between subjects of international law; they may therefore not be devoid of all legal consequences." 351

Other academics have criticized this approach, accepted the status of non-binding political commitments in international law, and emphasized the importance of such arrangements under international law. ${ }^{352}$ According to proponents of this viewpoint, political commitments have a rich historical basis and serve an important purpose in international law. ${ }^{353}$ These academics identify an earlier case, Greece v. Turkey, as the

349 KLABBERS, supra note 347, at 165.

350 In the Legal Status of Eastern Greenland, the Permanent Court of International Justice referred to a unilateral statement of the Norwegian foreign minister and concluded that "a reply of this nature given by the Minister of Foreign Affairs on behalf of his government in response to a request by the diplomatic representative of a foreign Power, in regard to a question falling within his province, is binding upon the country to which the Minister belongs." The Legal Status of Eastern Greenland (Nor. V. Den.) P.C.I.J, Rep. Series A/B, No. 53 (1933); see also, Nuclear Tests (Asutl. v. France), 1947 I.C.J. 253, 267. In Armed Activities on the Territory of Congo, the International Court of Justice declared that unilateral statements "can create legal obligations only if it is made in clear and specific terms." Case Concerning Armed Activities on the Territory of Congo (Dem. Rep. Congo v. Rwanda), Jurisdiction and Admissibility, 2006 I.C.J Reports 6, 28.

351 Anthony Aust, The Theory and Practice of Informal International Instruments, 3535 INT'L \& COMP. L.Q. 787, 807; see also KLABBER, supra note 347, at 110-112;

352 Duncan B. Hollis \& Joshua J. Newcomer, "Political" Commitments and the Constitution, 49 VA. J. INT'L L. 507, 517-518 (2009).

353 Id. at 510. 
natural counterpoint to Qatar v. Bahrain; ${ }^{354}$ In Greece v. Turkey, the International Court of Justice held that a formal communiqué between the Greek and Turkish Foreign ministers was neither binding on the parties nor sufficient to confer jurisdiction on the Court. $^{355}$

Scholars use several methods to determine whether an agreement is solely a political commitment or an authoritative and binding treaty under international law. In particular, they look at the language, context, and intent of states, as well as the substance of the agreements. ${ }^{356}$ Yet, even for the proponents of political commitments, the line between binding agreements and mere political commitments is unclear. ${ }^{357}$

These criteria indicate that the JCPOA, irrespective of the text, cannot be a mere political commitment. On the intent prerequisite, as discussed above, the parties do not agree that the document is legally binding. This fact reduces the chance that the intent of the states will be helpful in deciphering the text even if parties later state their intent retroactively. It is highly doubtful that the text itself and the concern over words such as "will" versus "shall" will offer much help: ${ }^{358}$ it has been the US position that language of this nature will not determine whether a deal is a political commitment or a treaty. ${ }^{359}$

354 See id. at 523, n.57.

355 Agean Sea Continental Shelf (Greece v. Turk.), 1978 I.C.J. 3, III 100-06 (Dec. 19).

356 See Hollis \& Newcomer, supra note 352, at 516-25; Schachter, supra note 346, at 296-300; see also similar criteria enumerated in the International Agreement Regulations Apr. 27, 1981 by the State Department implementing the Case Act 1 U.S.C. 112b(a).

357 Schachter, supra note 345, at 297-298.

358 Anthony Aust, supra note 351 at 800-802. ["taken on its own, however, the title of an instrument can be most misleading as to intention."]

359 Anthony Aust, Modern Treaty Law and Practice 40 (2007). ["But it is also clear that in the US practice use of non-treaty language does not necessarily preclude the instrument from being an 
More importantly, the context of the deal implies that it cannot be a mere political declaration, at least under international law. First, the JCPOA is designed to remain in effect over twenty-five years, with no sunset date for certain monitoring measures. ${ }^{360}$ Second, this deal is being negotiated against the backdrop of-and in order to resolvecomplex national, regional, and UN legal issues under the Treaty on the NonProliferation of Nuclear Weapons (NPT). Even if the US can "snap back" sanctions at will or under the JCPOA mechanism, it is not clear that sanctions will be as effective as they were before. Further, the snap-back mechanism can be interpreted to mean that "the American commitment is indeed binding unless and until 'a significant' breach has been established." 361

Finally, the parties have taken actions under their respective domestic laws that suggest that the deal might be more than a political commitment; For instance, the U.S. Congress passed the Iran Nuclear Agreement Review Act in May of 2015, a compromise solution between Obama and the Congress, in which agreement is defined generally "regardless of the form it takes, whether a political commitment or otherwise, and regardless of whether it is legally binding or not." 362 The Act clearly avoided taking any stance on the nature of

international agreement if 'the general content and context reveal an intention to enter into a legally binding relationship.']

360 Annex V (F), 26 ("The terminations described in this Annex V are without prejudice to other JCPOA commitments that would continue beyond such termination dates."); Dan Doyner, Much, Much More on the JCPOA, ARMS CONTROL LAW BLOG, July 15, 2015 ("I suspect that the U.S. delegation was keen to not have a general sunset clause in the JCPOA, so that it could truthfully tell Congress that the deal and at least some of its limitations on Iran's nuclear program were permanent.")

361 Ackerman \& Golove, Guest Post: The Lawless Presidency of Marco Rubio-a Reply to Professor Ku, supra note 335.

362 H.R. 1191, Pub. L. 114-17. 
the agreement and did not limit its authorization to the president to only non-binding commitments. ${ }^{363}$ Under Iranian law, international agreements must be ratified by the parliament and upon ratification it becomes part of the domestic law. ${ }^{364}$ The Iranian parliament also ratified the JCPOA in October of $2015 .^{365}$

\section{Sanctions and Iran Nuclear Deal}

In the Iran case, the Nuclear Deal has been cherished as a successful case of economic sanctions that brought a "rogue state" to the serious negotiation talks. ${ }^{366}$ It is hard to measure the effectiveness of economic sanctions. Some studies find them to be an effective way of changing the behavior of states, if properly implemented. ${ }^{367}$ Some do

363 Congressionally authorized executive agreements have provided the basis for 90 percent of the United States' international obligations, Ackerman \& Golove, Can the Next President Repudiate Obama's Iran Agreement?, supra note 335.

364 The Iranian Constitution states: "International treaties, protocols, contracts, and agreements must be approved by the Islamic Consultative Assembly." QANUNI ASSASSI JUMHURII ISLAMAI IRAN [THE CONSTITUTION OF THE ISLAMIC REPUBLIC OF IRAN] 1358 [1980], art. 77.

365 Iranian Parliament Ratifies Outlines of JCPOA, Tehran Times, October 12, 2015, available at http://www.tehrantimes.com/news/250028/Iranian-parliament-ratifies-outlines-of-JCPOA

366. Jim Sciutto, Senators Propose New Iran Sanctions Bill: White House Opposed, C.N.N., (Dec. 19th, 2013), http://www.cnn.com/2013/12/19/politics/iran-sanctions-senate/ (last visited Mar. 3, 2014). For instance Robert Mendez, a New Jersey Democrat Senator, declared "current sanctions brought Iran to the negotiating table." That was the reasoning behind his bi-partisan proposal to step up the level of pressure on Iran through enacting further economic sanctions. See id.

367 See generally Gary Clyde HufBauer et AL., ECONOMiC SANCTIONS RECONSIDERED (2009). 
not. ${ }^{368}$ Iran's case is no exception. It is very hard to gauge the effectiveness of economic sanctions in Iran's case.

Yet, recent rhetoric has centered on the fact that economic sanctions have been working and that the change in Iran's behavior came as a result of crippling economic sanctions. However, before one can conclude such a general statement, it is helpful to look at the following facts:

1. Sanctions showed their strongest impact from 2010 onwards. A web of economic sanctions imposed by the UN, the US and the EU aimed to strangle the Iranian economy, provoked social unrest and halted the Iranian Government's enrichment activity. ${ }^{369}$ The Iranian economy suffered tremendously as a result of sanctions. The Rial, the Iranian currency, lost almost half of its value. ${ }^{370}$ The sale of oil also dropped from 2.5 million barrels per day in 2011 to 1 million barrels per day in $2013 .{ }^{371}$ Yet, there is little evidence showing that the Iranian government suffered as result of these sanctions. ${ }^{372}$ As a Rentier

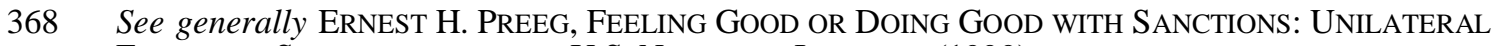
ECONOMIC SANCTIONS AND THE U.S. NATIONAL INTEREST (1999).

369 Nader Habibi, The Iranian Economy in the Shadow of Sanctions, in IRAN AND THE GLOBAL ECONOMY: PETRO PopUlism, ISLAM AND ECONOMIC SANCTIONS 172, 172-174 (Parvin Alizadeh \& Hassan Hakimian, eds., 2014).

370. Steven Plaut, The Collapse of Iran's Rial, GATEStONE InstituTe, (Feb 21, 2013, 5:00 AM), http: //.gatestoneinstitute.org/3597/iran-rial-collpase.

371. See Sanctions, Iran Matters: Best ANALysis and Facts on the Iranian Nuclear Challenge From HARVARD's Belfer Center, available at http://iranmatters.belfercenter.org/sanctions (last visited, Mar. 3, 2014). (providing a concise review of the impact of economic sanctions on Iran's economy).

372. See, e.g., Oren Dorell, Iran Nuclear Sanctions Hurt the Middle Class, not Guards, USA TODAY, Nov. 17, 2011, http://usatoday30.usatoday.com/news/world/story/2011-11-17/iran-nuclearsanctions-backfire/51275666/1; Beheshteh Farshneshani, In Iran, Sanctions Hurt the Wrong People N.Y. TIMES, Jan. 22, 2014, http://www.nytimes.com/roomfordebate/2013/11/19/sanctionssuccesses-and-failures/in-iran-sanctions-hurt-the-wrong-people; Jamal Abdi \& Trita Parsi, Opinion: Sanctions Against Iran Hurt the People, Not the Regime, NEWSDAY, Aug. 5, 2012, http:/l www.newsday.com/opinion/oped/sanctions-against-iran-hurt-the-people-not-the-regime-opinion1.3881126; Eskandar Sadeghi-Boroujerdi \& Muhammad Sahimi, The Sanctions Aren’t Working, FOREIGN POLICY, July 5, 2012, available at http://www.foreignpolicy.com/articles/2012/07/05/ the_sanctions_aren_t_working. 
State $^{373}$, those with special privileges continued to import and export from a black market, but this time even without any strong competitors from the Iranian domestic market.

2. Since the Iranian Revolution in 1979 , there have been several periods of social unrest, ${ }^{374}$ the last of which followed the June 2009 election. ${ }^{375}$ As far as analyses show, none of these periods of social unrest had a strong economic motive behind it: the Reformist Movement of 1997-2001 had political goals including promotion of democracy, rule of law as well as establishing a robust civil society. ${ }^{376}$ During student protests in 1999 , the main request was political in nature too, i.e. request for freedom. 377 In 2009, the crowd gathered in the streets because of their objection to the result of the

373. "Rentier States are defined here as those countries that receive on a regular basis substantial mounts [sic] of external rent. External rents are in turn defined as rentals paid by foreign individuals, concerns or governments to individuals, concerns or governments of a given country... a moment's reflection will reveal that oil revenues received by the governments of the oil exporting countries can also be external rents...the governments of the oil exporting countries in the Middle East benefit from differential and monopolistic rents that arise from higher productivity of the Middle Eastern oilfields and price fixing practices of the oil companies." Hossein Mahdavi, The Patterns and Problems of Economic Development in Rentier States: The Case of Iran, in STUDIES IN THE ECONOMIC History of THE MidDle EAST: From the Rise of ISLAM to the PRESENT Day 428, 428-29 (M.A. Cook ed. 1970) (footnote omitted).

374. See generally Simin Fadaee, Social Movements in Iran: Environmentalism and Civil Society (2012).

375. See e.g. Nazila Fathi \& Michael Slackman, Iran Stepping Up Effort to Quell Election Protest, NYTIMES, Jun. 24, 2009 available at http://www.nytimes.com/ 2009/06/25/world/middleeast/25iran.html? r=0; Timeline: Iran's Post Eleciton Protests, FinANCIAL TIMES, Jun. 11, 2010 available at http://www.ft.com/intl/cms/s/0/533d966e-755a-11dfa7e2-00144feabdc0.html\#axzz3GN4X6ujT.

376. MaJid Mohammadi, Judicial Reform and Reorganization in 20th CENTURy IRAN: STATEBUILDING, MODERNIZATION AND ISLAMICIZATION 184 (2008).

377 Student Protests Shake Iran's Government, N.Y. TIMES, July 11, 1999, http://www.nytimes.com/1999/07/11/world/student-protests-shake-iran-s-government.html. 
election. ${ }^{378}$ However, no major social unrest has been reported since the 2010 implementation of "crippling sanctions." 379

3. Economic sanctions also seem to be ineffective in halting nuclear enrichment activity of the Iranian Government. With 190 centrifuges before the sanctions, Iran extended its program to 19000 centrifuges following the 2010 sanctions. ${ }^{380}$ It seems that the sanctions came nowhere close to crippling the enrichment activity of the Iranian government.

4. Long before the recent stringent sanctions, Western countries had a better deal with Iran in 2003: total suspension of enrichment activity, not for 6 months but indefinitely (see Tehran Declaration). ${ }^{381}$ There was no discussion of the "right to enrichment" either. It was simply a better deal from the Western countries' perspective. ${ }^{382}$ After almost 10 years, with crippling sanctions in place, Iran is not suspending its entire enrichment, ${ }^{383}$

378. Robert F. Worth \& Nazila Fathi, Protests Flare in Tehran as Opposition Disputes Vote, N.Y. TiMES, June 13, 2009, http://www.nytimes.com/2009/06/14/ world/middleeast/14iran.html?pagewanted=all\&_r=0.

379. Akbar Ganji, US Crippling Sanctions Against Iran: A New Wave of Anti-Americanism (Part I), HUFFINGTON POST, Sep. 3, 2013, http://.huffingtonpost.com/akbar-ganji/us-crippling-sanctionsb 3860933.html.

380. See Iran's Nuclear Timetable, IRAN WATCH: TRACKING IRAN's UnCONVENTIONAL WEAPON CAPABILITIES, Feb. 21, 2014 available at http://www.iranwatch.org/our-publications/articlesreports/irans-nuclear-timetable (last visited, Mar. 3, 2014) (providing a quick overview of progress of Iran's nuclear program).

381. See Statement by the Iranian Government and Visiting EU Foreign Ministers, InTERNATIONAL ATOMIC ENERGY AGENCY, Oct. 21, http://www.iaea.org/newscenter/focus/iaeairan/statement iran21102003.shtml (last visited, Mar. 3, 2014). In 2003, a nuclear agreement reached between Iran and three European countries, i.e. England, France and Germany. In a trip to Tehran they signed a deal with Iran in which Iran pledged to suspend its nuclear enrichment, which it did. Id.

382. See Trita Parsi, No, Sanctions Didn't Force Iran to Make a Deal, ForeIGn Policy, May 14, 2014, available at http://.foreignpolicy.com/articles//05/14 /sanctions not force to make enrichment.

383. Id. 
and also in one reading, its "right to enrichment" is actually implicitly recognized. ${ }^{384}$ After all, the comprehensive deal-to-come should "involve[] a mutually defined (uranium) enrichment program."385

The nuclear deal, however, was successful partly because of the way constitutionalism in Iran is structured. The presidents need to gain the soft power by having a peaceful and cooperative relationship with other countries. Presidents do not enjoy having access to armed forces. Further, international deals such as the JCPOA create a normative structure around which presidents can project their power in domestic Iranian politics. Due to this important factor, engagement and international commitments play an important role in creating balance within Iranian politics and the Iranian constitution.

Further, the via media approach, calling the JCPOA a political commitment with legal consequences, ${ }^{386}$ invites a fundamental inquiry: What are the characteristics of a binding agreement if other than the fact that it would not be devoid of legal consequences? In other words, in international law where no legislative and executive body exist, one might conclude that instruments are 'binding' if they lead to legal consequences borne by

384. Mark Fitzpatrick, Assessing the Iranian Nuclear Deal, THE INTERNATIONAL INSTITUTE FOR STRATEGIC STUDIES, (Feb. 3, 2014), http://.iiss.org/en/events/events/archive/2014-f13/e91c/theiranian-nuclear-deal-076e.

385 Iran \& P5+1Joint Plan of Action, Preamble available at http://eeas.europa.eu/statements/docs/2013/131124_03_en.pdf.

386 See also Dan Joyner, The Trump Presidency and the Iran Nuclear: Initial Though, EUR. J. OF INT'L L. TALK, Nov. 17, 2016. ("some of the JCPOA's commitments - a number of which have already been implemented by the parties including by the U.N. Security Council itself - have legal implications. Iran's provisional application of the IAEA Additional Protocol, the U.N. Security Council's removal of its economic and other sanctions on Iran through Resolution 2231, and the removal of unilateral economic sanctions under domestic law by the U.S. and the European Union, have all already occurred as of Implementation Day, as stipulated in the JCPOA.") 
the parties. Further, if any commitments set forth in the JCPOA are deemed to be part of the respective state's international obligation, then "it is a principle of international law that the breach of an engagement involves an obligation to make reparation in an adequate form." 387

\section{A Different International Law}

Undoubtedly, world affairs and international law have changed significantly since the Cold War era, and three developments are particularly relevant here. First, international law has shifted course from consent-based dispute resolution toward a more compulsory framework. ${ }^{388}$ Generally speaking, states are bound by their agreements and are liable for the fulfillment of an obligation only if they objectively consent to undertake that obligation. As case law suggests, however, international courts and tribunals have increasingly found ways to extend their jurisdiction even without the explicit consent of states. The Oil Platform Case $^{389}$ before the International Court of Justice and the Loewen Case before a NAFTA ${ }^{390}$ tribunal serve as good examples in which the tribunals proceeded to adjudicate the matters even though they did not find jurisdiction proper. ${ }^{391}$

387 Case Concerning the Factory at Chorzow, P.C.I.J, Series A, No. 921, 23, July 26, 1927.

388 W. Michael Reisman, The Quest For WORLd ORDER AND HuMAN Dignity IN THE TwENTYFIRST CENTURY: CONSTITUTIVE PROCESS AND INDIVIDUAL COMMITMENT 208 (2012)

389 Case Concerning Oil Platforms (Islamic Republic of Iran v. United States of America), Preliminary Objection, Judgment of 12 December 1996. Paragraph 52. .

390 The Loewen Group, INC and Raymond L Loewen v. United States of America, Case No. ARB (AF)/98/3, award. June 23, 2006. The Tribunal assessed the criteria of exhaustion of local remedies (paragraph 172-217) even though it did not find jurisdiction to hear the case (paragraph 240).

391 See id. at 211-12. 
Another pivotal development is the increase of international fora and regimes, which has led to a highly fragmented system of law at the international level. ${ }^{392}$ This means that a "political commitment" in an arms deal might be construed differently in other contexts, such as investment law or international human rights.

Finally, a shift is noticeable in the principal method of interpretation partly as a result of expansion of international investment dispute resolutions. ${ }^{393}$ In international law, the dominant method of interpretation, as reflected in the Vienna Convention on the Law of Treaties, ${ }^{394}$ is textualist and formalistic. However, in recent years, the policy-based approach seems to have gained traction. ${ }^{395}$ When applying the policy-based approach, international tribunals consider the parties' stakes as well as the social and systemic consequences of their decisions, among other factors. ${ }^{396}$ More so than ever before, states that intend to enter political commitments rather than binding agreements may face tribunals that construe their pledge as legally binding.

392 See generally Study Group of the International Law Commission, Fragmentation of International Law: Difficulties Arising from the Diversification and Expansion of International Law, Int'l Law Comm'n, U.N. Doc. A/CN.4/L.682 (Apr. 13, 2006).

393 Todd Weiler, The InTERPRETATION OF InTERnATIONAL INVESTMENT LAW 29 (2013) ("These developments may well portend a pragmatic shift in international law.”)

394 Vienna Convention on the Law of Treaties art. 31, May 23, 1969, 1155 U.N.T.S. 331.

395 WeILER, supra note 393; REISMAN, supra note 388 at 193-194.

396 Reisman supra note 388at 183-184. See also Weiler, supra note 40, at 34-39. For a criticism of adopting an interpretation based on systemic implications, see Michael Reisman, 'Case Specific Mandates' versus 'Systemic Implications': How Should Investment Tribunals Decide? The Freshfields Arbitration Lecture, 23 ARB. INT'L 131, 131-132 (2013). 


\section{Conclusion}

Constitutions are designed to create metanorms to govern the polity. As Alex Stone Sweet stated:

"[A] constitution denotes a body of metanorms, rules that specify how legal norms are to be produced, applied, and interpreted. Metanorms are thus not only higher-order but prior, organic norms - they constitute a polity. Metanorms enhance the legitimacy of legal norms (and therefore social legitimacy) not unlike the way higher degrees of clarity enhance the legitimacy of norms generally: metanorms make more transparent the processes by which legal norms are produced, compliance is monitored, and infractions punished. Thus, metanorms fix the rules of the game, as a means of investing lower-order norms with authority (legitimacy). To the extent that these rules are expected to be longlived, or quasi-permanent, the establishment of metanorms is an institutionalization of the social interest." 397

Hence, Iranian presidents, especially in the post-establishment era resorted to creating the metanorms by acceding to international regimes. In other words, the presidents, in the post-establishment era, have defined their presidency partly or wholly by their approach to international commitments and international law. This was an endeavor to create metanorm domestically needed to balance powers.

397 Alex Stone Sweet, What is a Supranational Constitution?: An Essay in International Relations Theory, 56.3 THE REV. OF POLITICS 441, 444 (1994).(emaphsis original) 
As shown in the discussion above, none of the proponents and opponents during the constitutional deliberation took the view that popular vote should categorically be rejected. Although there are considerable disagreements among the representatives, it is important to note that even proponents of Guardianship of a Jurist discussion did not view it or envision it as a replacement for popular governance. For some of them this principle was the framework to protect the 'excesses' of popular voting. For others, the fact that the leader itself would be appointed (indirectly) by popular vote signified that it was not in contradiction with the principle of popular vote.

In the Khomeini era, despite Iran's contentious foreign policies, in cases where the tension could escalate into conflict, Iran opted for resolution of disputes through international law. This could be partly due to external pressure. Yet, it is important to note that Iran remained compliant with the regimes to which it voluntarily subscribed.

In post-Khomeini Iran, international relations and international law played an instrumental role in balancing power and creating norms that were needed for such balance in domestic politics. In this phase, the normative framework, resulting from the evolution of constitutionalism, along with international commitments created a normative structure by which presidents were viewed as pro-cooperation while the supreme leader was viewed as a proponent of autarky. This is partly or wholly due to the structure of the Iranian constitution and the deficiency created in constitution, which needed to be filled with engagement with international law.

In addition, the geo-culture of Iranian society, borrowed from three main sources i.e. preIslamic Iran, Shiite, and Western influence has proven to be quite legalistic in approach. 


\section{References}

Abbas Miani, Eminent Persians 369-370 (2008).

Abbas Milani, The Shah 273 (2011-2012).

Akbar Ganji, US Crippling Sanctions Against Iran: A New Wave of Anti-Americanism (Part I), Huffington Post, Sep. 3, 2013, http://.huffingtonpost.com/akbar-ganji/uscrippling-sanctions-_b_3860933.html.

Alec Stone Sweet, Constitutionalism, Legal Pluralism, and International Regimes, 16 Ind. J. Global Legal Stud. 621, 626 (2009).

Alec Stone Sweet, What is a Supranational Constitution? An Essay in International Relations Theory, 56 The Rev. of Politics, 441, 443 (1994).

Alex Stone Sweet, What is a Supranational Constitution?: An Essay in International Relations Theory, 56.3 The Rev. of Politics 441, 444 (1994).

Ali Gheissari \& Vali Reza Nasr, Democracy in Iran: History and the Quest for Liberty 94 (2006).

Alireza Nader et al, The Next Supreme Leader: Succession in the Islamic Republic of Iran 37 (2011).

Andrew Guzman, Why LDCs Sign Treaties that Hurt Them: Explaining the Popularity of Bilateral Investment Treaties, 38 Virginia J. Int'1 L. 639 (1998).

Andrew Moravcsik, Integrating International and Domestic Theories of International Bargaining in Double-edge Diplomacy: International Bargaining and Domestic Politics 3, 7-9 (Peter Evans et al eds.,1993).

Anne Peters, The Merits of Global Constitutionalism. 16 Ind. J. Global Legal Stud, 397, 397 (2009).

Anne-Marie Slaughter, International Law in a World of Liberal States, 6 Eur. J. Int'1 L. 503, 537 (1995).

Anoushiravan Ehteshami, After Khomeini: The Iranian Second Republic (2002).

Anthony Aust, Modern Treaty Law and Practice 40 (2007).

Anthony Aust, The Theory and Practice of Informal International Instruments, 3535 Int'1 \& Comp. L.Q. 787, 807 
Asli Bali \& Bernard Haykel, Can Turkey or Lebanon be Models for a New Arab Political Order? Debating Law \& Religion Series, Yale Law School, Feb. 4, 2014.

Asli Bâli, A Turkish Model for the Arab Spring? 3 Middle East L. and Govern. 1 (2011).

Babak Ganji, Politics of Confrontation: The Foreign Policy of the USA and

Revolutionary Iran 150 (2006).

Baqer Moin, Khomeini: Life of the Ayatollah 221 (2000).

Bart Barnes, Former Secretary of State Warren Christopher, Who Negotiated Settlement to Iran Hostage Crisis, Dies at 85, The Washington Post, March 19, 2011, available at: https://www.washingtonpost.com/local/obituaries/former-secretary-of-state-warrenchristopher-dies-at-85/2010/09/21/ABCPk6t story.html?utm term=.8c1de9b1579c

Bayram Sinkaya, The Revolutinary Gaurds in Iranian Politics: Elites and Shifting 88 (2016).

Beheshteh Farshneshani, In Iran, Sanctions Hurt the Wrong People N.Y. Times, Jan. 22, 2014, http://www.nytimes.com/roomfordebate/2013/11/19/sanctions-successes-andfailures/in-iran-sanctions-hurt-the-wrong-people;

Behrooz Moazami, State, Religion, and Revolution in Iran, 1796 to the Present 117-119 (2013).

Bernard Lewis, The Crisis of Islam: Holy War and Unholy Terror 141-142 (2004)

Beverley Milton-Edwards, Islamic Fundamentalism Since 1945 81-83 (2005)

Bradley Klapper, Kerry says Congress would not be able to change terms of Iran deal, PBS Newshour (Mar. 11, 2015, 1:41 PM), http://www.pbs.org/newshour/rundown/kerrysays-congress-able-change-terms-iran-deal

Bruce Ackerman \& David Golove, Can the Next President Repudiate Obama's Iran Agreement? The Atlantic, September 10, 2015 available at https://www.theatlantic.com/politics/archive/2015/09/can-the-next-president-repudiateobamas-iran-agreement/404587/

Bruce Ackerman \& David Golove, Guest Post: The Lawless Presidency of Marco Rubioa Reply to Professor Ku, Opinio Juris, Sept. 16, 2015, available at http://opiniojuris.org/2015/09/16/guest-post-the-lawless-presidency-of-marco-rubio-areply-to-professor-ku/;

Bruce Ackerman, Constitutional Politics/ Constitutional Law, 99 Yale L. J. 453 (1989);

Bruce Ackerman, Constitutional Politics/Constitutional Law, 99 Yale L. J., 453, 461 (1989)

Bruce Ackerman, The Storrs Lectures: Discovering the Constitution, 93 Yale L. J. 1013 (1984).

Bruce Ackerman, We the People: Foundations (1993).

Bruce Ackerman, World Constitutionalism, (Work-in-Progress). 
Can Trump Kill Iran Nuclear Deal Just by Walking Away? Yes, U.S. Officials, World Tribute, Nov. 13, 2016, available at http://www.worldtribune.com/can-trump-kill-irannuclear-deal-by-walking-away-yes-say-u-s-officials/

Charles Kurzman: The Unthinkable Revolution in Iran 1 (2004).

Charles N. Brower \& Jason D. Brueschke, The Iran-United States Claims Tribunal 7-10 (1998).

Colum Lynch \& John Hudson, Obama Turns to U.N. to Outmaneuver Congress, Foreign Policy, July 15, 2015, available at http://foreignpolicy.com/2015/07/15/obama-turns-to-un-to-outmaneuver-congress-iran-nuclear-deal/

Cynthia Weber, Simulating Sovereignty: Intervention, the State and Symbolic Change 4 (2001)

Dan De Luce, Trump Mulls Squeezing Iran with Tougher Sanctions, Foreign Policy Blog, April 17, 2017 available at http://foreignpolicy.com/2017/04/17/trump-mulls-squeezingiran-with-tougher-sanctions/

Daniel Brumberg, Reinventing Khomeini: The Struggle for Reform in Iran 142 (2001).

Daniel Young, How Do You Measure a Constitutional Moment? Using Algorithmic Topic Modeling To Evaluate Bruce Ackerman's Theory of Constitutional Change, 122 Yale L. J. 1990 (2013).

David Farber, Taken Hostage the Iran Hostage and America's First Encounter with Radical Islam 1-2 (2005).

David Grewal, Book Review: The Laws of Capitalism by Thomas Piketty, 128 Harv. L. Rev. 626, 652 (2014).

David Grewal, Network Power: the Social Dynamics of Globalization 247-258 (2008)

David Law \& Mila Versteeg, The Evolution and Ideology of Global Constitutionalism, 99 Cal. L. Rev. 1163, 1163 (2011).

David Menashri, Iran in Middle East Contemporary Survey 341, 346 (Bruce MaddyWeitzman ed., vol. 21, 1997).

David Phillips, On this Day 35 (2007).

Dawood Ahmed \& Tom Ginsburg, Constitutional Islamization and Human Rights: The Surprising Origin and Spread of Islamic Supremacy in Constitutions, Public Law and Legal Theory Working Paper No 477, University of Chicago at 7. available at http://chicagounbound.uchicago.edu/cgi/viewcontent.cgi?article=1919\&context=public_1 aw_and_legal_theory

Detailed Discussion of Assembly of Constitutional Experts (Soorate Mashroo Mozakerat Majles Baressi Nahai Ghanoon Asasi Jomhori Islami), Sessions 32 to 50, pp. 944-945, available at http://www.majlesekhobregan.ir/fa/pdf/tadvin_qaanoon_asaasi/qaanoone asaasi-2.pdf 
Detailed Discussion of Assembly of Constitutional Experts (Soorate Mashroo Mozakerat Majles Baressi Nahai Ghanoon Asasi Jomhori Islami), Sessions 1 to 31, pp. 373-376 available at http://www.majlesekhobregan.ir/fa/pdf/tadvin_qaanoon_asaasi/qaanoone_asaasi-1.pdf

Duncan B. Hollis \& Joshua J. Newcomer, "Political" Commitments and the Constitution, 49 Va. J. Int'1 L. 507, 517-518 (2009).

Duncan Hollis, The Iran Deal as a Political Commitment, Opinio Juris (Apr. 2, 2015, 6:00 PM), http://opiniojuris.org/2015/04/02/the-iran-deal-as-a-political-commitment; see also Duncan Hollis, Dealing with Iran: A Primer on the President's Options for a Nuclear Agreement, Opinio Juris (Mar. 11, 2015, 2:52 PM), http://opiniojuris.org/2015/03/11/dealing-with-iran-a-primer-on-the-presidents-optionsfor-a-nuclear-agreement. For the conservative characterization of the deal,

E.H. Carr, The Twenty Years' Crisis 1919-1939, 166 (Palgrave 2001) (1964);

Edward McWhinney, Supreme Courts and Judicial Law-Making: Constitutional Tribunals and Constitutional Review 20 (1986).

Eline Gordts, Iran's Foreign Minister To U.S. Senators: 'The World Is Not the United States', Huffington Post (Mar. 9, 2015, 5:34 PM), http://www.huffingtonpost.com/2015/03/09/zarif-senators-letter_n_6834296.html. Zarif

Elton L. Daniel, The History of Iran, 140 (2012).

Emmanuel Adler \& Peter M. Haas, Conclusion: Epistemic Communities, World Order, and the Creation of a Reflective Research Program, 46 Int'l Org. 367, 367 (1992).

Ernest H. Preeg, Feeling Good or Doing Good with Sanctions: Unilateral Economic Sanctions and the U.S. National Interest (1999).

Ervand Abrahamian, Khomeinism: Essays on the Islamic Republic 18-19(1993)

Ervand Abrahamian, The Causes of the Constitutional Revolution in Iran, 10 Int'1 J. of Middle East Studies 381, 412 (1979)

Eskandar Sadeghi-Boroujerdi \& Muhammad Sahimi, The Sanctions Aren't Working, Foreign Policy, July 5, 2012, available at http://www.foreignpolicy.com/articles /2012/07/05/the_sanctions_aren_t_working.

Establishment of Expediency Discernment Council, Islamic Revolution Document Center, available at http://www.irdc.ir/fa/calendar/81/default.aspx.

Evaleila Pesaran, Iran's Struggle for Economic Independence: Reform and CounterReform in the Post-Revolutionary Era 136 (2011).

Extension of Iran Sanctions Act Passes US Congress, Reuter, December 1, 2016 available at http://www.jpost.com/Middle-East/Extension-of-Iran-Sanctions-Act-passesUS-Congress-474245; Jordain Carney, Senators to Trump: We Support Additional Iran Sanctions, The Hill, February 2, 2017, available at http://thehill.com/blogs/flooraction/senate/317682-senators-to-trump-we-support-additional-iran-sanctions 
Farshad Ghodoosi, Defining the Relationship: Terminology and the Iran Deal, Foreign Affairs, April 5, 2015, available at https://www.foreignaffairs.com/articles/unitedstates/2015-04-05/defining-relationship

Fatima Ahmad Alsmadi, The 'Iranian Model' is no inspiration for Arabs, Aljazeera, Oct. 5, 2014, http://www.aljazeera.com/indepth/opinion/2014/10/iranian-model-noinspiration-a-2014105101919853679.html

Francois Nicoullaud, Iran's NPT Withdrawal Option, Lobe Log, 12 January 2015.

Gary Clyde Hufbauer et al., Economic Sanctions Reconsidered (2009).

Gary J. Jacobsohn, Constitutional Identity 4 (2010)

Hans Morgenthau and Kenneth Thompson, Politics Among Nations (McGraw-Hill, 6th ed.1985) (1948)

Harold Koh, Review Essay: Why do Nations Obey International Law? 106 Yale L. J. 2599 (1996).

History of Maritime Clashes between Iran and United States, BBC Persian, August 26, 2016. (in Farsi), available at http://www.bbc.com/persian/iran/2016/01/151231_145_iran_us_military_confrontation

Homa Katouzian, State and Society in Iran: The Eclipse of the Qajars and the Emergence of the Pahlavis 314 (2006).

Hossein Bashiriyeh, Cleavages in Iranian Politics Since 1979, in Politics \& Culture in Contemporary Iran: Challenging the Status Quo, 33, 42-43 (Abbas Milani \& Larry Diamond, eds., 2015).

Hossein Mahdavi, The Patterns and Problems of Economic Development in Rentier States: The Case of Iran, in Studies in the Economic History of the Middle East: From the Rise of Islam to the Present Day 428, 428-29 (M.A. Cook ed. 1970) (footnote omitted).

Hossein Modaressi, Crisis and Consolidation in the Formative Period of Shi'ite Islam (1993)

Iran Nuclear Deal Can Be Secured by UN Security Council Resolution-Russian Diplomat, APA (Apr. 16, 2015, 1:45 AM), http://en.apa.az/xeber_iran_nuclear_deal_can_be_secured_by_un_s_225842.html;

Iran: The White Revolution, Time Magazine, Feb 11, 1966.

Iran's Nuclear Timetable, Iran Watch: Tracking Iran's Unconventional Weapon Capabilities, Feb. 21, 2014 available at http://www.iranwatch.org/ourpublications/articles-reports/irans-nuclear-timetable (last visited, Mar. 3, 2014) (providing a quick overview of progress of Iran's nuclear program).

Iulia E. Padeanu, Is the Trump Administration Bound by the Iran Deal? Yale J of Int'1 L Online, Dec. 1, 2016 available at http://campuspress.yale.edu/yjil/is-the-trumpadministration-bound-by-the-iran-deal/ 
Jack Balkin, Living Originalism 3 (2011).

Jack Godsmith, Why Congress is Effectively Powerless to Stop the Iran Deal (and Why the Answer is Not the Iran Review Act), Lawfare, July 20, 2015, available at https://www.lawfareblog.com/why-congress-effectively-powerless-stop-iran-deal-andwhy-answer-not-iran-review-act;

Jack Goldsmith, How a U.N. Security Council Resolution Transforms a Non-Binding Agreement with Iran Into a Binding Obligation Under International Law (Without Any New Senatorial or Congressional Vote), Lawfare (Mar. 12, 2015, 8:37 AM), http://www.lawfareblog.com/2015/03/how-a-u-n-security-council-resolution-transformsa-non-binding-agreement-with-iran-into-a-binding-obligation-under-international-lawwithout-any-new-senatorial-or-congressional-vote;

Jahangir Amuzegar, Iran's Economy Under the Islamic Republic 4-7 (1997).

Jahangir Amuzegar, The Dynamics of the Iranian Revolution: The Pahlavis's Triumph and Tragedy 53-54 (1991).

Jamal Abdi \& Trita Parsi, Opinion: Sanctions Against Iran Hurt the People, Not the Regime, Newsday, Aug. 5, 2012, http://www.newsday.com/opinion/oped/sanctionsagainst-iran-hurt-the-people-not-the-regime-opinion-1.3881126;

James Curry et al, Constitutional Government: The American Experience 6 (2003).

James Strucke, Hilary Clinton: 'Iran is moving toward a military dictatorship', The Guardian, Feb. 15th, 2010.

Jan Klabbers, The Concept of Treaty in International Law 163-64 (1996).

Jim Sciutto, Senators Propose New Iran Sanctions Bill: White House Opposed, C.N.N., (Dec. 19th, 2013), http://www.cnn.com/2013/12/19/politics/iran-sanctions-senate/ (last visited Mar. 3, 2014).

John B Bellinger, How Binding Is the Iran Deal? Council on Foreign Relations, July 23, 2015, available at http://www.cfr.org/iran/binding-iran-deal/p36828

John Cushman, U.S. Strikes 2 Iranian Oil Rigs and Hits 6 Warships in Battles over Mining Sea Lanes in Gulf, N.Y. Times, April 19, 1988.

John G. Collier and Vaughan Lowe, The Settlement of Disputes in International Law: Institutions and Procedures 75 (2000).

Judith Goldstein et al, Introduction: Legalization and World Politics, 54 Int'1 Org. 385, 391 (2000).

Judith Yaphe, Changing American Perspectives on the Iran-Iraq War, in The Iran-Iraq War: New International Perspectives 178, 178 (Nigel Ashton \& Bryan Gibson eds., 2013).

Julian Ku, Iran Responds to US Senators' Letter, Shows Why Congress Should Be Involved in the First Place, Opinio Juris (Mar. 9, 2015, 10:08 AM), http://opiniojuris.org/2015/03/09/iran-responds-to-us-senators-letter-shows-whycongress-should-be-involved-in-the-first-place. 
Julian Ku, President Rubio/Walker/Trump/Whomever can Indeed Terminate the Iran Deal on "Day One", Opinio Juris, September 10, 2015 available at http://opiniojuris.org/2015/09/10/president-rubiowalkertrumpwhomever-can-indeedterminate-the-iran-deal-on-day-one/;

Kelsey Davenport, Iran Dismantling Centrifuges IAEA Says, Arms Control Association, December 2015, available at https://www.armscontrol.org/ACT/2015_12/News/IranDismantling-Centrifuges-IAEA-Says

Kenneth Abbott \& Duncan Snidal, Why States Act Through Formal International Organizations 42 J. Conflict Resol. 3, 9-23 (1998).

Kenneth J. Vandevelde, A Brief History of International Investment Agreement, 12 U.C. Davis J. Intl' L. \& Policy 157, 167-169 (2005-2006).

Kenneth J. Vandevelde, Bilateral Investment Treaties, 1 (Oxford University Press 2010).

Kenneth Waltz: Kenneth Waltz, Man, the State, and the War (Columbia University Press, 2001) (1959).

Laura Rozen, Iran, P5+1 Reach 'Historic' Framework Deal, Al Monitor, April 2, 2015, available at http://www.al-monitor.com/pulse/originals/2015/04/zarif-iran-deal-reactionslausanne-nuclear-talks.html

Lawrence Tribe, A Constitution We are Amending: In Defense of a Restrained Judicial Role, 97 Harv. L. Rev. 443, 440 (1983).

Leonard W. Levy, Original Intent and the Framers' Constitution (1988).

Leonard Weinberg \& Amir Pedahzur, Introduction in Religious Fundamentalism and Political Extremism 5-6 (Leonard Weinberg \& Amir Pedahzur eds, 2004).

Majid Mohammadi, Judicial Reform and Reorganization in 20th Century Iran: StateBuilding, Modernization and Islamicization 184 (2008).

Maziar Behrooz, Factionalism in Iran under Khomeini, 27 Middle Eastern Stud. 597, 597 (1991).

Mehdi Moslem, Factional Politics in Post-Khomeini Iran 25 (2002).

Mehran Kamrava, Khomeini and the West in A Critical Introduction to Khomeini 156157 (2014).

Meliha Benli Altunisik, The Turkish Model and Democratization in the Middle East, 27 Arab Stud. Q. 45 (2005)

Michael Axworthy, Revolutionary Iran: A History of the Islamic Republic 7 (2013).

Michael Klarman, Constitutional fact/Constitutional Fiction: A Critique of Bruce Ackerman's Theory of Constitutional Moments, 44 Stan. L. Rev. 759 (1992)

Michael Reisman, International Law-making: A Process of Communication, 75 Am. Soc'y Int'1 L. Proc. 101,113 (legal process consists of "policy content, authority signal and control intention.") 
Michael Richards, Revolution in World History 73 (2004)

Michael W. Doyle, Liberalism and World Politics, 80 Am. Pol. Sci. Rev. 1551, 1551 (1986).

Mohiaddin Mesbahi, Trust and U.S.-Iran Relations: Between the Prisoners' Dilemma and the Assurance Game, 4 Iranian Rev. of Foreign Affairs, 7, 31 (2013).

Mohsen Milani, The Making of Iran's Islamic Revolution 2 (Westview Press, 1994).

Mohsen Milani, The Making of Iran's Islamic Revolution: From Monarchy to Islamic Republic (1994).

Morteza Kazemian, Reviewing Eight Parliamentary Elections in Islamic Republic of Iran, BBC Persian, Dec. 23, 2011, BBC Persian available at http://www.bbc.co.uk/persian/iran/2011/12/111221_139_majlis9th_8-terms\#second

Mustafa Aykol, Turkey vs. Iran: The Regional Battle for Hearts and Minds, Foreign Affairs, Mar. 21, 2012, available at http://www.foreignaffairs.com/articles/137343/mustafa-akyol/turkey-vs-iran

Myres McDougal \& Harold Lasswell, The Identification and Appraisal of Diverse Systems of Public Order, 53 Am. J. Int'1 L. 1, 9 (1959)

Nader Habibi, The Iranian Economy in the Shadow of Sanctions, in Iran and the Global Economy: Petro Populism, Islam and Economic Sanctions 172, 172-174 (Parvin Alizadeh \& Hassan Hakimian, eds., 2014).

Nazila Fathi \& Michael Slackman, Iran Stepping Up Effort to Quell Election Protest, NYTimes, Jun. 24, 2009 available at http://www.nytimes.com/ 2009/06/25/world/middleeast/25iran.html? r=0

Nicholas S. Zeppos, Justice Scalia's Textualism: The "New” New Legal Process, 12 Cardozo L. Rev. 1597 (1990).

Nikki Keddie, Modern Iran: Roots and Results of Revolution 260 (2003).

Nikkie R. Keddie, Modern Iran: Roots and Results of Revolution 27-30 (2003).

Noah Feldman, Islamic Constitutionalism in Context: A Typology and a Warning, $7 \mathrm{U}$. St. Thomas L. J. 436, 443 (2010).

Obama Renews National Emergency on Iran, Tehran Times, January 14, 2017, available at http://www.tehrantimes.com/news/410050/Obama-renews-national-emergency-onIran.

Oren Dorell, Iran Nuclear Sanctions Hurt the Middle Class, not Guards, USA Today, Nov. 17, 2011, http://usatoday30.usatoday.com/news/world/story/2011-11-17/irannuclear-sanctions-backfire/51275666/1;

Oscar Schachter, The Twilight Existence of Nonbinding International Agreements, 71 Am. J. Int'1 L. 296, 304 (1977).

P.J. Tierney, Theocracy: Can Democracy Survive Fundamentalism? Resolving the Conflict between Fundamentalism and Pluralism 106 (2012) 
Pardis Mahdavi, Iran's Green Movement in Context in Cultural Revolution in Iran: Contemporary Popular Culture in the Islamic 13, 19 (2013).

Paul w. Kahn, The Reign of Law: Marbury v. Madison and the Constitution of America 4-5 (1997)

Peter Jones, Arab Spring: Opportunities and Implications, 67 Int'1 J 447 (2011); Seyla Benhabib, The Arab Spring: Religion, revolution and the public sphere, Eurozine (May 10, 2011), available at: http://www. eurozine. com/articles/2011-05-10-benhabib-en;

Qanuni Assassi Jumhuri Islamai Iran [The Constitution of the Islamic Republic of Iran] 1358 [1980], art. 81.

Raja Bahlul, Is Constitutionalism Compatible with Islam? in The Rule of Law History, Theory and Criticism, 515, 515 (2007).

Richard H. Steinberg, Wanted-Dead or Alive: Realism in International Law in Interdisciplinary Perspective on International Law and International Relations 146, 146148 (2013).

Rob Johnson, The Iran-Iraq War 44-45 (2011)

Robert D. Putnam, Diplomacy and Domestic Politics, The Logic of Two-Level Games, 42 Int'1 Org. 427, 460 (1988).

Robert F. Worth \& Nazila Fathi, Protests Flare in Tehran as Opposition Disputes Vote, N.Y. Times, June 13, 2009, http://www.nytimes.com/2009/06/14/ world/middleeast/14iran.html?pagewanted=all\&_r=0.

Robert Keohane, After Hegemony: Cooperation and Discord in the World Political Economy 107 (1984).

Robert M. Axelrod, The Evolution of Cooperation 60-63 (1984).

Robert O. Keohane \& Joseph S. Nyle, Power and Interdependence Revisited, 41 Int'1 Org. 725, 731 (1987).

Rosalyn Higgins, Natural Resources in the Case Law of the International Court, in International Law and Sustainable Development 87, 101 (eds., Alan Boyle \& David Freestone, 1999).

Said Amir Arjomand, After Khomeini: Iran Under His Successor 31 (2009).

Said Amir Arjomand, Ideological Revolution in Shiism in Authority and Political Culture in Shiism (Said Amir Arjomand, ed. 1988).

Saïd Amir Arjomand, Islam and Constitutionalism since the Nineteenth Century: the Significance and Peculiarities of Iran in Islam and Constitutional Politics in the Middle East: With Special References to Turkey, Iraq, Iran and Afghanistan, 33, 34-35 (2008).

Saïd Amir Arjomand, Revolution and Constitution in the Arab World in Beyond the Arab Spring: The Evolving Ruling Bargain in the Middle East 151,165 (2014).

Said Amir Arjomand, The Turban for the Crown: the Islamic Revolution in Iran 144 (1988). 
Sepehr Zabir, The Left in Contemporary Iran 97 (1986)

Seymour Lipset \& Jason Lakin, The Democratic Century 19 (2004).

Simin Fadaee, Social Movements in Iran: Environmentalism and Civil Society (2012).

Simon Kriesberg et al, US Sanctions Against Iran: Outlook Under President Trump, Law 360, Jan. 3, 2017, available at https://www.law360.com/articles/877002/us-sanctionsagainst-iran-outlook-under-president-trump;

Statements of Dr. Jamshid Momtaz, Iranian Diplomacy, 27 August 2014, available at http://www.irdiplomacy.ir/en/page/1937512/Comprehensive+Agreement+Depends+on+ Lifting+of+Sanctions.html

Stephen Krasner, Structural Causes and Regime Consequences: Regimes as Intervening Variables in International Regimes 1,1 (1983).

Stephen W. Walt, Revolution and War 247 (1996)

Steve Bruce, Fundamentalism 46 (2008).

Steven O'Hem, Iran's Revolutionary Guard: The Threat That Grows While America Sleeps 20-21 (2012).

Steven Plaut, The Collapse of Iran's Rial, Gatestone Institute, (Feb 21, 2013, 5:00 AM), http://.gatestoneinstitute.org/3597/iran-rial-collpase.

Sujit Choudhry, Ackerman's Higher Lawmaking in Comparative Constitutional Perspective: Constitutional Moments as Constitutional Failures? 6 Int'1 J. Const. L. 193 (2008);

Sun Tzu, The Art of War.

Tim Mak, GOP Goes_Ballistic Over Plan to Take the Iran Nuke Deal to the U.N., The Daily Beast (Mar. 12, 2015, 9:30 PM), http://www.thedailybeast.com/articles/2015/03/12/gop-goes-ballistic-over-plan-to-takethe-iran-nuke-deal-to-the-u-n.html.

Timeline: Iran's Post Eleciton Protests, Financial Times, Jun. 11, 2010 available at http://www.ft.com/intl/cms/s/0/533d966e-755a-11df-a7e2-

00144feabdc0.html\#axzz3GN4X6ujT.

Trita Parsi, Losing an Enemy: Obama, Iran, and the Triumph of Diplomacy 303 (2017).

Trita Parsi, No, Sanctions Didn't Force Iran to Make a Deal , Foreign Policy, May 14, 2014, available at http://.foreignpolicy.com/articles//05/14

/sanctions not force to make enrichment.

United States Department of State, Letter to Mike Pompeo, Nov. 19, 2015. Also available at http://www.nationalreview.com/article/427619/state-department-iran-deal-not-legallybinding-signed (emphasis added)

Unspoken Words of Hashemi about the Dismissal of Ayatollah Montazeri, available at:

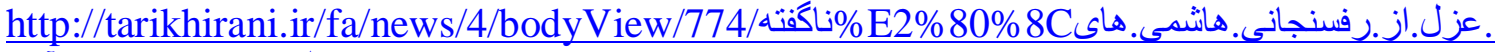
منتظرى.الله E2\%80\%8Chl 
Vali Nasr, Forces of Fortune: The Rise of the New Muslim Middle Class and What it Will Mean for Our World 132-135 (2009).

Vali Nasr, The Shia Revival, How Conflicts within Islam Will Shape the Future 74-75 (2006)

Walter Burnham, Constitutional Moments and Punctuated Equilibria: A Political Scientist Confronts Bruce Ackerman's 'We the People’, 108 Yale L. J. 2237 (1999)

William H. Rehnquist, The Notion of a Living Constitution, 54 Tex. L. Rev. 693, 694

Williamson Murray \& Kevin Woods, The Iran-Iraq War: A Military and Strategic History 143-145 (2014).

Yeganeh Torbani, Trump Election Puts Iran Nuclear Deal on Shaky Ground, Reuters, Nov. 1, 2016, available at http://www.reuters.com/article/us-usa-election-trump-iranidUSKBN13427E

Yervand Abrahamian, Mosadegh valued constitutionalization of Monarchy as much as he valued nationalization of oil, 24 March 2012 available at

http://tarikhirani.ir/fa/news/30/bodyView/1981/ را.سلطنت.شدن.مشروطه.مصدق.:آبر اهاميان.يرو اندان.

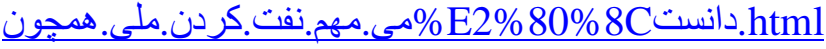

Zachary Elkins et al, The Endurance of National Constitutions 6 (2009). 


\section{CURRICULUM VITAE}

\section{FARSHAD GHODOOSI}

Born, Tehran, Iran

2001-2005

LL.B. in Law

University of Tehran

Tehran, Iran

2005-2008

LL.M. in Private and Islamic Law

University of Tehran

Tehran, Iran

2011-2015

LL.M. and J.S.D.

Yale Law School

New Haven, Connecticut

2009-2018

Doctoral Candidate

Florida International University

Miami, Florida

\section{PUBLICATIONS AND PRESENTATIONS}

International Dispute Resolution and the Public Policy Exception (Routledge, 2016).

Arbitrating Public Policy: Why the Buck Should Not Stop at National Courts, 20 Lewis and Clark Law Review 237 (2016)

The Concept of Public Policy in Law: Revisiting the Role of the Public Policy Doctrine in the Enforcement of Private Legal Arrangements, 94 Nebraska Law Review 685 (2016)

The Limits of the Free Movement of Capital: The Status of Customary International Law of Money, 7 Northwestern Interdisciplinary Law Review. 287 (2014).

Combatting Economic Sanctions: Investment Disputes in Times of Political Hostility, 37 Fordham International Law Journal 1732 (2014). 